\title{
Destined for democracy? Labour markets and political change in colonial British America
}

\author{
Elena Nikolova* \\ Forthcoming, British Journal of Political Science
}

\begin{abstract}
This paper proposes a new explanation for the emergence of democratic institutions: elites may extend the right to vote to the masses in order to attract migrant workers. I argue that representative assemblies serve as a commitment device for any promises made to labourers by those in power, and test the argument on a new political and economic data set from the thirteen British American colonies. The results suggest that colonies that relied on white migrant labour, rather than slaves, had better representative institutions. These findings are not driven by alternative factors identified in the literature, such as inequality or initial conditions, and survive a battery of validity checks.
\end{abstract}

What explains the emergence and persistence of democratic institutions? Recent research shows that there may be multiple answers to this question. Scholars have linked the probability of democratic transition and consolidation to economic development (Lipset, 1959; Boix, 2011); historical path dependence and revolution (Acemoglu and Robinson, 2006; Acemoglu et al., 2012; Przeworski, 2009); social learning (Gleditsch and Ward, 2006); and financial openness (Freeman and Quinn, 2012). Some have argued that societies with a highly unequal income distribution

${ }^{*}$ Research Economist, European Bank for Reconstruction and Development. Email: nikolove@ebrd.com. My deepest gratitude goes to Carles Boix, Grigore Pop-Eleches and Jeff Hammer for many discussions, advice and encouragement. I am also grateful to the Editor, three referees and Alicia Adsera, Toke Aidt, Shekhar Aiyar, Ralph De Haas, Stanley Engerman, Ruben Enikolopov, Christina Gathmann, Simon Hess, Kosuke Imai, Marina Kaloumenou, Ilyana Kuziemko, Nolan McCarty, Maria Petrova, Jessica Trounstine, Andrea Vindigni, Joachim Voth, and participants at several seminars and conferences. The views expressed in this paper are those of the author only and not necessarily of the EBRD. 
- which in turn may be driven by differences in initial factor endowments - are less likely to be democratic, as the rich may prefer an authoritarian regime due to redistribution pressures from a low-income median voter (Boix, 2003; Engerman and Sokoloff, 2000, 2002, 2005). Democratic institutions will thus emerge and be sustained in instances of relatively low inequality, as the redistribution from rich to poor is minimal.

This paper studies one particular political institution, voting rights, to propose an altogether different reason behind political liberalisation: elites may use the franchise as a tool to attract migrant labour. Focusing on the political evolution of the thirteen British American colonies from the early seventeenth century until the American Revolution, I show that those colonies which relied on white immigrant workers, rather than slaves, had a more liberal franchise. For example, the Northern colonies had both a more liberal suffrage and a higher proportion of white settlers, while, in the eighteenth century, the Southern colonies combined a restrictive franchise with a large slave population. ${ }^{1}$ These institutional differences are hardly surprising and have been documented by others. In the North, the staple crop (wheat) could be efficiently grown on small family farms, which may have contributed to a more egalitarian income distribution, and therefore better political institutions (Engerman and Sokoloff, 2000, 2002, 2005). Alternatively, it is possible that the temperate Northern climate appealed to entire white migrant families, which may have sought to replicate British political institutions, emphasising private property and controls on government power (Acemoglu et al., 2001).

Although such theories are important, they come short of explaining a different puzzle which emerges from the data analysed in this paper. This puzzle lies in the

\footnotetext{
${ }^{1}$ The South includes Maryland, Virginia, South Carolina and North Carolina, while the North includes Massachusetts, Rhode Island, Connecticut, New Hampshire, New York, New Jersey, Pennsylvania and Delaware.
} 
observation that, despite the hot and disease-ridden climate which was suitable for growing labour intensive cash crops (such as tobacco and rice), the Southern colonies actually had a more inclusive suffrage than the North throughout the seventeenth century. During this period, African slaves were largely unavailable, so Southern landowners recruited European labour through the system of indentured servitude, under which migrants "tied" themselves to a colonial landowner for several years in exchange for a loan covering transportation costs from Europe. I argue that Southern elites initially allowed nearly all adult males to vote in order to attract immigrant workers. A liberal suffrage was highly desirable for such migrants, since assemblies in which they were adequately represented guaranteed fair enforcement of indenture contracts. As in the North, representative institutions also prevented the expropriation of land titles and private property of landowners and newly freed servants. $^{2}$

However, the arrival of slavery in the Southern colonies in the late seventeenth and early eighteenth centuries prompted planters to substitute white labourers with cheaper and easily available slaves. Political concessions to white workers were no longer warranted, so Southern elites immediately tightened the suffrage. In contrast, the Northern franchise remained liberal and largely unchanged throughout the colonial period. Black labourers were only of marginal importance, as agricultural work was done on small family farms without the need for much additional labour.

To test the hypothesis about labour market structure as a determinant of the colonial suffrage, I assemble an original data set covering the thirteen British American colonies from the early seventeenth century to the American Revolution. In order to capture the quality of political institutions, I create an index that aggregates, for

\footnotetext{
${ }^{2}$ For more on how political institutions can serve as a commitment device for self-interested elites, see Acemoglu and Robinson (2006); Olson (2000); Congleton (2010), and North and Weingast (1989).
} 
each colony-year observation, the presence of various restrictions on the franchise, such as those related to income, land ownership or religion. I measure labour market composition by tracing the spread of slavery via data on each colony's share of the black population. I use the percentage of a colony's white landless population to estimate inequality, where higher percentage landless implies higher inequality. In addition, I control for a rich set of additional variables, ranging from urbanisation and population density to colonial settlement patterns.

I use four complementary approaches to show that in the thirteen British American colonies, differences in labour markets had a causal impact on the quality of political institutions. First, I construct a new instrument for the extensiveness of slavery based on each colony's propensity to produce one of the two labour-intensive crops (tobacco and rice), interacted with the prices of these crops. The idea behind this instrument is that once the prices for labour-intensive crops increase, landowners will seek to acquire additional labour, turning to slaves if white labourers are not sufficient or are too expensive. I also use the prices of slaves in the Caribbean - the largest slave market throughout the colonial period which set prices for the rest of the New World - as an alternative proxy for the prevalence of black workers in the Southern colonies. Third, I control for time-invariant colony characteristics, such as geographical or climate differences, which may affect both labour markets and the suffrage by including colony fixed effects. Finally, in the online Appendix I supplement the econometric results with a detailed historical discussion of the link between labour markets and the franchise in the colonies, which also includes (fragmentary) migration data.

This paper offers several contributions to the literature. By linking the composition of human capital and representative institutions, I not only enrich the inequality-democracy theories developed in previous work, but also suggest a mechanism through which slavery could affect economic and political outcomes over the 
long term (Acemoglu et al., 2012). ${ }^{3}$ Moreover, I break away from the cross-country regression approach on which other similar studies rely and which has been criticised due to problems of data inconsistency, unit heterogeneity and endogeneity (Pande and Udry, 2005; Atkinson and Brandolini, 2001). The main advantage of my research design stems from my ability to trace the political and economic development of the thirteen colonies from their very settlement until 150 years later. In addition, I observe substantial variation in colonial political institutions, as from the very beginning, each colony was given complete freedom to shape - as well as alter - its representative institutions without any interference from England.

The idea that political institutions, by serving as a commitment device, can credibly constrain the power of elites has been developed in several earlier studies, including Congleton (2011) for the case of the North American colonies and states, as well as Fleck and Hanssen (2006) and Fleck and Hanssen (2009) for ancient Greece. ${ }^{4}$ My findings also resonate with those of a small but growing literature which demonstrates that one reason why US states with smaller female population enfranchised women earlier was to attract them as settlers (Braun and Kvasnicka, 2013; Kenny, 1999, 2004). A separate strand of research has also linked the quality of institutions to migration. Bertocchi and Strozzi (2008) and Engerman and Sokoloff (2005) argue that electoral institutions mattered for attracting European migrants to the New World in the 19th century. Fleck and Hanssen (2013) find a correlation between government quality and the opportunities for population exit in cross-country data.

This paper enhances such work in at least three important ways. First, my theory applies the institutional commitment mechanism to a new problem: how to

\footnotetext{
${ }^{3}$ For recent work challenging the link between inequality and democracy, see Ansell and Samuels (2010); Haggard and Kaufman (2012) and Houle (2009).

${ }^{4}$ In Congleton's model, rather than being the driving factor, labour scarcity catalyses institutional reforms which occur through a process of constitutional bargaining.
} 
prevent self-interested elites from reneging on migration inducements once costly migration has taken place. Second, unlike previous work, my argument considers the joint impact of labour market structure and income inequality on representative institutions. Third, a major strength of the paper lies in the use of a unique data set and research setup which makes identification concerns in the empirical analysis less pressing, something which is generally difficult to achieve with similar historical data.

The remainder of the paper is organised as follows. The next section outlines the theoretical argument, while section 3 discusses the data. Sections 4 and 5 present the empirical set up and the results, respectively. Section 6 focuses on validity threats, and the last section concludes.

\section{Theoretical argument}

\section{Colonial labour market patterns}

The primary goal of American settlement was to remedy the twin problems of scarcity of land and abundance of labour facing England in the 17th century. While some colonies were governed directly by the Crown, it was more common for either one or several wealthy Englishmen to gain ownership of a colony, which gave them substantial control over political and economic affairs. Migrant labour was essential for growing high-profit crops such as tobacco, rice and wheat, which were then exported to Europe (Purvis, 1999). As a result, the successful development of each colony and the wealth of its proprietors - depended on attracting English migrants. ${ }^{5}$

\footnotetext{
${ }^{5}$ The majority of English settlers went to the colonies because of the availability of economic opportunities. However, some migrants (such as the Quakers who established Pennsylvania) left England because of religious persecution.
} 
Despite the importance of immigration, attracting settlers to the colonies was not easy. Even the poorest labourers had alternatives to moving overseas, such as going to a different part of the countryside, to London or to Ireland (Kulikoff, 2000, p. 44; 53). Moreover, the journey across the Atlantic was long, dangerous and expensive, with its price exceeding half a year's income for a typical English immigrant (Rosenbloom, 2008). What is more, information about the difficulties of colonial life traveled relatively easily from the colonies to the mainland, as highly literate colonists wrote often, and even the illiterate could hire someone to write for them (Kulikoff, 2000, p. 47-48).

Colonial elites adopted different strategies for populating the colonies. In the North, the temperate climate encouraged a steady inflow of migrant families. Settlers were given small plots of land, which they used to cultivate wheat without the need for additional labour. In contrast, the hot and disease-ridden climate of the South, along with an agriculture centered around the production of labour-intensive crops (such as tobacco and rice), made attracting migrants difficult.

While some slaves found their way to the colonies in the seventeenth century, through the hands of Dutch privateers or large planters who migrated from the West Indies, the supply of black labour was generally limited by the high demand for slaves in the Caribbean, as well as by the tight regulation of the slave trade by the English government. Southern elites therefore recruited European labour mainly through the system of indentured servitude, under which migrants "tied" themselves to a landowner for several years in exchange for a loan covering transportation costs. Master-servant relations were regulated through contracts, which stipulated the length and conditions of the indenture, wages and any dues, such as land, payable once the servant was free. Given that the end-of-contract payments were substantial - sometimes comprising up to $66 \%$ of a contract's price, servants were often able to set up their own farms once their indentures were over (Grubb, 2000; Wertenbaker, 
1922). As a result, the supply of free white labour in the South was largely inelastic, except at very high wage levels. Recruiting workers from other colonies was also costly not only because planter settlements were separated by thick forests, but also because Southern roads, which were built to accommodate the transportation of export crops from plantations to the coast, were of very low quality (Kulikoff, 1986, p. 209-210).

Although the indenture system worked well for most of the seventeenth century, the supply of English servants plummeted toward the end of the period as economic conditions in the mother country improved. At the same time, the availability of African slaves rapidly increased at the beginning of the eighteenth century, driven by the rising English share in the slave trade and the low profitability of West Indies sugar production (Gray and Thompson, 1933, p. 352-354). While slavery had a limited impact on Northern labour markets, as family farms continued to dominate production, in the South it prompted the relatively quick substitution of indentured servants with slaves. As Table A2 shows, in the early eighteenth century, blacks comprised nearly two thirds of the population of South Carolina, and nearly one third of that in Virginia. Even though Southern planters initially preferred white workers, by 1710 they had learned that slaves were just as productive, and "sought them avidly every time a slave ship arrived" (Kulikoff, 1986, p. 41). In fact, landowners used slaves not only for agricultural tasks, but also trained blacks for more highly skilled occupations, such as builders and craftsmen. ${ }^{6}$

\footnotetext{
${ }^{6}$ In all colonies, some sort of Indian slavery or servitude existed throughout the colonial period. However, Indian labourers never became as popular as blacks (or as indentured servants) for several reasons. First, four colonies, (Virginia, South Carolina, Rhode Island, and New York), declared Indian enslavement illegal. Second, Indians were highly prone to disease, making them less suited for rice and tobacco production than blacks. Other reasons included the decline of Indian tribes driven by disease and fighting with the whites; the migration of Indian populations westward; as well as the better knowledge of the surrounding areas which made escape easier for Indians than
} 


\section{The link between labour markets and the suffrage}

This subsection argues that one factor which explains why some colonies opted for a liberal franchise was the degree to which their labour markets depended on white migrant workers. When white workers were difficult to obtain - as in the South prior to the arrival of slavery - colonial governments granted the franchise to virtually all males, in order to attract settlers. ${ }^{7}$ In those colonies where white labour was easier to attract - such as in the Northern colonies - additional suffrage regulations, such as the requirement of owning land or property, were introduced. The most restrictive regimes, which required voters to satisfy a combination of requirements, including landholding, property, taxpaying and residency, were adopted in the South once slaves replaced white indentured servants in the late seventeenth and early eighteenth centuries.

Why was a liberal suffrage important for Englishish migrants? Although all colonies were under English rule, representative assemblies, established soon after settlement, enjoyed significant prerogatives including complete control over law making and colonial finances. Therefore, political institutions in which labourers were adequately represented ensured that rules, regulations and policies that were relevant for them could not be easily changed by those in power. In particular, building on seminal work by Acemoglu and Robinson (2006), Congleton (2010) and North and Weingast (1989), I argue that representative assemblies served as a commitment device for any promises made to migrants by ruling elites.

In the North, wheat growing took place on small family farms, so an inclusive suffrage guaranteed not only that new settlers obtained the amount of land promised

for blacks. Moreover, Indians were perceived to have "irregular work habits," as well as to be more likely to engage in savage acts if provoked (Ward, 1991, p. 122-123).

${ }^{7}$ Most American states did not allow women to vote until the Nineteenth Amendment which came into force in 1920. 
to them by proprietors before arrival, but also that their land, property or profits could not be taken away once they had settled. In the South, the protection of property rights was relevant for those few settlers that had set up their own farms. More importantly, representative institutions had an additional purpose, namely to aide the enforcement of labour contracts on which the indenture system was based. In order to undertake the long and arduous trip across the Atlantic, potential servants needed a guarantee that landowners will not alter contract terms or expropriate their wages once they arrived in the colonies, or once their contracts were over. Since masters often refused to comply with the terms agreed in the contract, colonial assemblies played an active role in devising laws regulating servant-master relations (Weinberg, 2003).

Of course, political institutions are only one of the ways to credibly constrain the power of elites. The rule of law - such as an impartial and independent court system - can be used to both effectively resolve contracting disputes, and to force

governments to respect private property (Congleton, 2010). The development of colonial courts, however, tended to lag behind that of political institutions (Surrency, 1967). While courts existed in some colonies, judges were seldom impartial as they were appointed by large proprietors. Court independence was also a problem, as judges and assemblymen often ruled on disputes in which they themselves were involved (Morgan, 1975).

\section{The role of inequality}

Building on the idea that representative assemblies force elites to credibly commit to promises made to migrant workers, the previous subsection has developed an argument linking the composition of labour markets and the extensiveness of the colonial franchise. At the same time, the presented theory also enriches existing inequalitydemocracy models. According to Boix (2003), elites are more likely to implement 
an autocratic system when inequality increases, due to redistribution threats from a low-income median voter. In contrast, Acemoglu and Robinson (2006) argue that the inequality-democracy relationship follows an inverted U-shape. In their story, the negative effect of inequality on democracy working through redistribution is mitigated by the higher likelihood of democratic revolution when inequality is high. Since democratisation occurs as a commitment to future redistribution, the stronger the threat of revolution, the more likely elites will be to cede democracy.

While I examine the independent role of revolutionary threats in the penultimate section of the paper, it is possible that inequality, through its effect on redistribution, exerts an effect on the franchise that is independent from that of labour markets. A first question to ask is to what extent redistributive transfers mattered in the thirteen colonies. Although an advanced system of taxation and redistribution did not emerge until after the American Revolution, several percentage points of the average colonist's income went to taxes (Rabushka, 2002). ${ }^{8}$ Colonial governments used these proceeds to finance in-kind redistribution, rather than pure monetary transfers, such as poor relief, as well as the building of roads, bridges, and schools (Rabushka, 2002; Einhorn, 2008; Fishback, 2006).

The extent to which labour market structure affects the relationship between inequality and the suffrage depends on the trade-off between the redistributive costs of a particular franchise regime and its benefits of securing migrant labour. On one hand, liberal representative institutions under high inequality are particularly costly for elites due to the losses associated with relinquishing assembly control to the poor, such as higher levels of redistribution. On the other hand, an inclusive suffrage may also attract white workers, and thus increase elite incomes when labour is difficult to obtain. Although redistribution in the thirteen colonies was non-negligible, labour

\footnotetext{
${ }^{8}$ In fact, several colonies, among which Massachusetts and South Carolina, had well-developed tax systems.
} 
market issues were of even greater importance, as the survival and progress of each colony depended on attracting a sufficient number of workers. I therefore expect that even though inequality may still have a negative effect on the extensiveness of the franchise, labour markets will be the primary determinant of political institutions.

One concern about this theoretical model is the potential relationship between labour markets and inequality. For instance, the spread of slavery in the South in the early eighteenth century not only decreased the importance of white workers, but also may have led to the establishment of large plantations. This could have exacerbated the income differences between large landowners and the rest of the population, leading to a deterioration in the suffrage in the Southern colonies. However, the historical evidence shows that such a scenario is not entirely convincing, as slavery did not lead to a dramatic shift in the Southern income distribution (Main, 1965). I investigate this concern in more detail in the penultimate section of the paper.

\section{Testable predictions}

The preceding discussion suggests that differences in labour market organisation across colonies, driven by the varying importance of white workers, may have had a direct effect on the extensiveness of the suffrage. Colonies that needed to attract white labourers opted for more democratic institutions, which served as a commitment device for promises made to migrants. However, the previous subsection has also shown the labour-franchise link is moderated by income inequality, as attracting poor labourers by extending the suffrage also imposes redistribution costs which are particularly high when incomes are unequally distributed.

This framework suggests two empirically testable hypotheses:

Hypothesis 1. Liberal representative institution will be observed in those colonies in which white labourers are important. The substitution of white workers with slaves 
will lead to a contraction of the franchise.

Hypothesis 2. Higher inequality will have a negative effect on the colonial franchise. The impact of inequality will be lower than that of labour market structure.

\section{Data}

\section{A new data set on representative institutions}

This subsection discusses the data used in the regressions to follow. More detailed information on the data is available in the online Appendix (Part 3).

Suffrage To examine trends in colonial political institutions, I compile a new data set which codes, for each colony and annually from the first year of its establishment, all the different restrictions that governments placed on the suffrage. I draw on the extensive study of the suffrage in the thirteen colonies by McKinley (1905), which I cross-checked against other more recent work, such as Rusk (2001) and Dinkin (1977). Even though the general reliability of the McKinley study was also confirmed by Stanley Engerman, it is very likely that the data set measures representative institutions with error. This should be partly mitigated by the fact that historians agree that the suffrage restrictions on the books were binding, suggesting that the franchise rules that I code should be highly correlated with those that were actually enforced (Dinkin 1977, 47-48; Rusk 2001).

I create a suffrage index to use as dependent variable in the regression analysis below as follows. First, I extract a list of all the franchise regulations in force in any particular colony from 1619 to 1775 , such as those related to income, property or religion (the complete is available in the online Appendix, Part 3). For each colonyyear observation and suffrage restriction, I create a variable that takes a value of 1 if voters needed to satisfy this particular regulation, and 0 otherwise. I do not focus 
on requirements for voting in local elections, as these differed very little from those for colony elections.

Suffrage restrictions were almost always introduced or removed in combination with others, so I aggregate these data into a suffrage index, and do not focus on restriction-by-restriction analysis instead. In order to do so, I need to account for the fact that colonies which allowed voters to satisfy a choice of two or more voting requirements likely had a more liberal franchise than those who imposed one of those restrictions. For example, while from 1698 onward, North Carolina required all voters to be freeholders, during the same period Maryland allowed electors who did not possess land to vote if they owned property worth at least 40 pounds. I therefore give the freeholding restriction in North Carolina a weight of 1 , while in Maryland the restrictions for (1) freeholding, and (2) income or property, each carry a weight of one quarter, respectively. As I assume that having a choice of two voting criteria is only half as restrictive as needing to satisfy one of those criteria, the sum of the two Maryland restrictions is thus one half. A similar approach is adopted when one suffrage requirement can be substituted with two or three others, yielding sums of one third and one fourth, respectively. I add up all the different restrictions coded in this way and subtract from this sum the maximum number of suffrage restrictions observed in the sample (6.5) to obtain the final suffrage variable used in the regressions. I give periods without elections - for instance, when the representative assembly is appointed by the governor - a suffrage value of 0 . As a result, a higher value of the suffrage index implies better political institutions.

To illustrate how my coding works, consider the case of South Carolina. From 1669 until 1691, the South Carolina suffrage index takes a value of 5.5, as the colony allowed all freemen to vote (obtained by subtracting a coding for the existence of a single restriction from the maximum number of restrictions in the sample (6.5)). In 1692 , electors instead had to possess income or property worth ten pounds, and to 
take an oath, so I code the existence of restrictions for income or property, minimum income or property, and oath taking, yielding a suffrage index of 3.5 (obtained by subtracting 3 from 6.5). In 1697, an additional requirement for three-month residence in the colony prior to election was introduced, which decreases the suffrage index to 2.5 (obtained by subtracting 4 from 6.5 ). In 1704, all previous requirements were kept, but voters were given a choice to satisfy either the ten-pound income or property requirement, or the possession of land of fifty acres. I give a weight of one quarter for both of the latter requirements, which means that the suffrage index now takes a value of 4 (obtained by subtracting 2.5 from 6.5 ).

Of course, it must be acknowledged that this weighting scheme is crude. An accurate assessment of the relative importance of each restriction entails comparing, for each colony, the proportion of the population that was eligible to vote under each criterion (Przeworski, 2009). In the absence of such evidence, I adopt three approaches to test the reliability of my coding. First, I experiment with several alternative operationalisations of the suffrage index, including (1) assigning equal weights to all component restrictions (which means that I do not account for any possible substitutions among restrictions); (2) assigning weights of $1 / 2$ and $1 / 3$ (instead of $1 / 4$ and $1 / 9$ ) to restrictions that can be substituted with one other or two other restrictions, respectively; and (3) using principal component analysis, which creates data-dependent weights. ${ }^{9}$ The correlations with these new indices are quite high (above 0.8), and the empirical results are very similar. Second, the effect of labour markets on the suffrage also survives when I instead replace my original suffrage index with a binary variable (which takes a value of 1 if any of the following restrictions are in place: income, freeholding, the existence of minimum freeholding or property, tax, residency or religion; and 0 otherwise). All of these results are

\footnotetext{
${ }^{9} \mathrm{I}$ perform orthogonal varimax rotation, and only keep the factor with the biggest eigenvalue, which explains 0.26 of the variance.
} 
available in Table A4.

Third, I assemble some fragmentary data on suffrage extensiveness in the colonies (covering mostly the 18th century) and investigate its correlation with the suffrage index. Figures A2 and A3 show that the relationship is positive, as expected, and ranges from 0.237 if racial restrictions are accounted for to 0.356 if they are excluded. The correlation is also positive for the period $1775-1860$ and takes a value of $0.4 .{ }^{10}$ I therefore conclude that while not perfect, the constructed suffrage index should be an informative measure of the quality of representative institutions in colonial British America.

Labour markets I hypothesised that more liberal political institutions will be observed in those colonies that depend on white labourers, implying that colonies that find it harder to attract white labour should have more democratic regimes. To empirically evaluate this argument, one would ideally compile, for each colony and over time, data on the importance of indentured servants, free white labour, family labour, and slaves, as well as estimates of the demand for and supply of each labour group.

Since such detailed information is unavailable, I make use of data on the percentage of each colony's black population from Historical Statistics of the United States, Millennial Edition Online (2006). While this is a simple proxy based on fairly reliable data, it is an imperfect measure of the whites and blacks actually in the labour force. ${ }^{11}$ Moreover, this measure does not capture differences in white labour scarcity

\footnotetext{
${ }^{10}$ This is based on data from Keyssar (2000) to extend the suffrage index, and Rusk (2001) for data on suffrage extensiveness. Unfortunately, the Rusk extensiveness data only cover franchise laws related to citizenship, race, age and sex, and excludes important laws related to economic qualifications or residency.

${ }^{11}$ I also collected information on slave arrivals from the Trans-Atlantic Slave Trade Database (www.slavevoyages.org). However, these data are less precise than the share of the black population,
} 
across colonies. To account for the latter, I control for each colony's density of the white population. I also collect colony-level data on life expectancy and the sex ratio of men over women, but I do not have enough observations to include these variables in the regressions, so I present simple correlations with the franchise index in Figures A4 and A5. ${ }^{12}$ While population density is generally insignificant in the regressions - possibly because it proxies for other variables, such as differences in economic development, colonies with more men and a lower life expectancy had a more liberal suffrage, which is consistent with my theory.

I supplement this measure with two additional labour market proxies. First, to capture the arrival of slavery in the South in the late seventeenth and early eighteenth century, I create a binary variable that is 1 for the South after 1700, and 0 for all other colonies and years. The idea is that such an indicator, albeit crude, would appropriately account for all three events which increased the supply of slaves in the South around 1700: the rising English share in the slave trade; the low profitability of West Indies sugar production; and the decrease in the supply of English indentured servants. Second, I also collect data from Eltis et al. (2005) on the prices of slaves in the Caribbean to construct an alternative proxy for the prevalence of black workers in the Southern colonies. Since the Caribbean was the largest slave market throughout the colonial period which set prices for the rest of the New World, high Caribbean slave prices should decrease the demand for - and the number of - new slaves in the South.

as slave ships did not land in those Southern colonies with coastlines that were difficult to navigate, such as Maryland.

${ }^{12}$ Scholars agree that colonies which found it difficult to attract white migrants had a high proportion of men, which made it difficult to produce a steady labour supply or to attract whole families (Purvis 1999). 
Income inequality According to the presented theory, income inequality, through its effect on redistribution, may be an important factor in determining the quality of colonial political institutions. Unfortunately, income distribution data for colonial America is unavailable, so I instead utilise the percentage of a colony's white landless population building on data from several secondary sources described in the online Appendix. The argument is that as percentage landless increases, so does income inequality.

While this inequality proxy is clearly less precise than a more direct measure, such as a Gini coefficient, there are several reasons why it should capture at least some of the variation in the colonial income distribution. First, an extensive literature has documented a positive correlation between the unequal distribution of land and an unbalanced distribution of income (Vanhanen, 2002; Boix, 2003; Ramcharan, 2010). ${ }^{13}$ This was particularly true for colonial America, where land - through its use for the production of export crops - was the major source of income and wealth, both in the North and the South. Moreover, historians agree that the main class divide in the colonies was between the few large landowners (colonial proprietors and their friends) and landless labourers (indentured servants in the South, or poor whites in the North) (Risch 1937, Jordan 2002). The wealth of colonial elites, amassed from the very beginning through land grants and tax breaks granted by the Crown, changed little over time. In addition, the share of the largest land-owning class (middle farmers owning between 100 and 500 acers) stayed relatively constant: for instance, in South Carolina, 60 percent of landowners held between 100 and 500 acres (Cooper, 2000, p.6-7). As a result, taking into account those marginal farmers that shift from landlessness to owning land (and vice versa) should track closely changes

\footnotetext{
${ }^{13}$ In fact, a well-accepted inequality measure in this literature - the area of family farms as a percentage of the total area of landholdings - is quite similar to the share of the white landless population used here.
} 
in the overall income distribution.

Indeed, the share of the white landless population correlates well with other (less extensive) measures of colonial economic inequality, such as the share of taxable wealth of the top $10 \%$ of the population paying the largest wealth tax (the correlation is 0.389). ${ }^{14}$ To dig deeper into the relationship between the white landless share and inequality, I look beyond the colonial period and exploit land distribution data for the American states covering the period 1860-1920, the earliest period for which such data are available. While there is no information on the percentage of the population with no landholdings, there is data on the number of farms under 10 acres, which should approximate, at least to some extent, owning no land (farm size in the 19th century US ranged from 41 to 468 acres, with a mean of 175 acres). The correlation between the proportion of farms under 10 acres and the land Gini coefficient is 0.589 , which again suggests that percentage landless should account for a significant proportion of the variation in the colonial income distribution.

Additional control variables Differences in economic development across colonies may have an independent effect on the colonial suffrage through at least two mechanisms. Colonies that are richer may not only be better able to afford the redistributive costs of a democratic regime, but higher income per capita may also make it more likely that citizens support the rule of law and democratic elections (Welzel and Inglehart, 2007).

To capture economic development, I rely on data on colonial urbanisation and white population density from Purvis (1999) and Historical Statistics of the United States, Millennial Edition Online (2006). The basic idea is that, in the absence of income per capita data, in the pre-industrial period large urban populations could thrive only in areas with high agricultural productivity and a developed transporta-

\footnotetext{
${ }^{14}$ These data are from Main (1965).
} 
tion network, and that only relatively prosperous areas could generally support dense populations (Acemoglu et al., 2001). Controlling for urbanisation is also important for ruling out concerns that rising percentage landless may be driven by the rise of cities and the decline of agriculture, rather than by an increase in income inequality. While this issue is less relevant for the South, which remained mostly agricultural and relatively rural throughout the colonial period, it matters for the North, where urban centers gained economic importance, particularly in the eighteenth century (see Nash, 1979). As argued above, white population density may also proxy for the degree of labour scarcity of white workers.

In the regressions to follow, I also control for the type of colonial settlement, using information from Purvis (1999). While charter colonies originated when the Crown granted patents and a land grant to a corporation or trustees, in other colonies a single or several proprietors were in charge of colonial affairs. In contrast, royal colonies were governed directly by England through an appointed governor. It is possible that proprietary and charter colonies, lacking the burden of royal supervision, may have had a stronger incentive to liberalise the suffrage in order to attract migrants.

\section{Descriptive and graphical evidence}

Table A1 presents summary statistics for the evidence I collected. For each colonial region, it breaks down the data into two panels: before and after 1700, the approximate arrival of slavery in the South. The third column in each of the two time panels reports the difference in the means across the two groups of colonies. This information is supplemented by the graphical evidence in Figures 1a and 1b. Figure 1a plots, for each Southern colony and using annual data, the suffrage index (left hand-side panel), and percentage black (right hand-side panel). Figure 1b does the same for the colonies in the North. For ease of reading, for each year, each graph presents three data points only: the maximum value of the suffrage or percent black 
variable observed across all colonies in the region (red circle), the minimum value (blue triangle), and the value obtained using lowess smoothing (black line).

A quick look at the data reveals several interesting patterns. First, while the black population of the South increased rapidly in the late seventeenth and early eighteenth centuries (reaching an average of 40 per cent by the 1750s), the average slave share in a typical Northern colony was less than 10 per cent during this period. Moreover, these differences in labour market structure tracked closely the evolution of political institutions in the two regions. In the seventeenth century, the franchise in the South was in fact very liberal (by around 1.3 restrictions as compared to the North). In contrast, an average Southern colony in the eighteenth century now required voters to satisfy 1.5 more requirements in order to vote, as compared to a colony in the North. Table A1 also shows that the South-North inequality gap (proxied by the regional difference in the percentage of the white landless population) did increase from 3.7 percentage points before 1700 to 11.2 percentage points. Nevertheless, the most dramatic change was observed in the South-North difference of the share of the black population: before 1700 , this difference was only 5.9 percentage points, but after 1700 it increased nearly fivefold.

To study in more detail this reversal in Southern representative institutions, Figure 2a graphs, for each of the Southern colonies, the joint evolution of suffrage and labour markets. Figure $2 \mathrm{~b}$ does the same for suffrage and inequality. Despite some existing difference in climate, crops, and the timing of settlement across the Southern colonies, the regional-level relationships are consistent with this more disaggregated analysis. All four colonies started off with liberal suffrage institutions, which however deteriorated sharply in the late seventeenth and early eighteenth centuries. This political transformation was accompanied by an equally dramatic rise in the share of the slave population, which in all colonies exceeded $25 \%$ of the population by the mid-1700s. Slavery was most prevalent in South Carolina, where in 1700, nearly half 
of the population was black.

Figure $2 \mathrm{~b}$ shows that the Southern political reversal is unlikely to have been driven by rises in inequality following the arrival of slavery. While inequality did increase to some extent in Maryland in the early eighteenth century and beyond, this was not the case in the other three colonies: in Virginia, percent landless stayed relatively constant, while in South and North Carolina, it actually went down. For comparability, Figures A6. A9 in the online Appendix present the same disaggregated graphical analysis of suffrage, inequality and the share of blacks for the Northern colonies. In the North, both suffrage institutions and the composition of colonial labour markets changed little, while inequality shifts do not seem to correspond to movements in the suffrage.

\section{Empirical setup}

\section{Base model}

While the previous subsection has uncovered correlations that are consistent with the presented theory linking labour markets and the suffrage, it is important to examine this relationship in a more systematic way. In order to do so, I employ the following econometric model:

$$
\begin{aligned}
& \text { Suffrage }_{c t}=\alpha+\beta_{1} \text { Suffrage }_{c t-1}+\theta_{1} \text { Labour }_{c t-1}+\theta_{2} \text { Inequality }_{c t-1}+ \\
& \beta_{2} \text { Urbanisation }_{c t-1}+\beta_{3} \text { Density }_{c t-1}+\mathbf{X}_{c t-1} \beta_{4}+\gamma_{t}+\mu_{c}+\varepsilon_{c t}
\end{aligned}
$$

where Suffrage $_{c t}$ is the suffrage index in colony c and time period t; Suffrage st-1 $_{c}$ is lagged suffrage; Labour $r_{c t-1}$ is percentage black; Inequality It-1 $_{c t}$ is percentage white landless; Urbanisation ${ }_{c t-1}$ is the share of the urban population; Density ${ }_{c t-1}$ is population density; $\mathbf{X}_{c t-1}$ is a vector of additional controls (dummies for the years in 
Figure 1: Evolution of suffrage and labour markets, by region

(a) Southern colonies
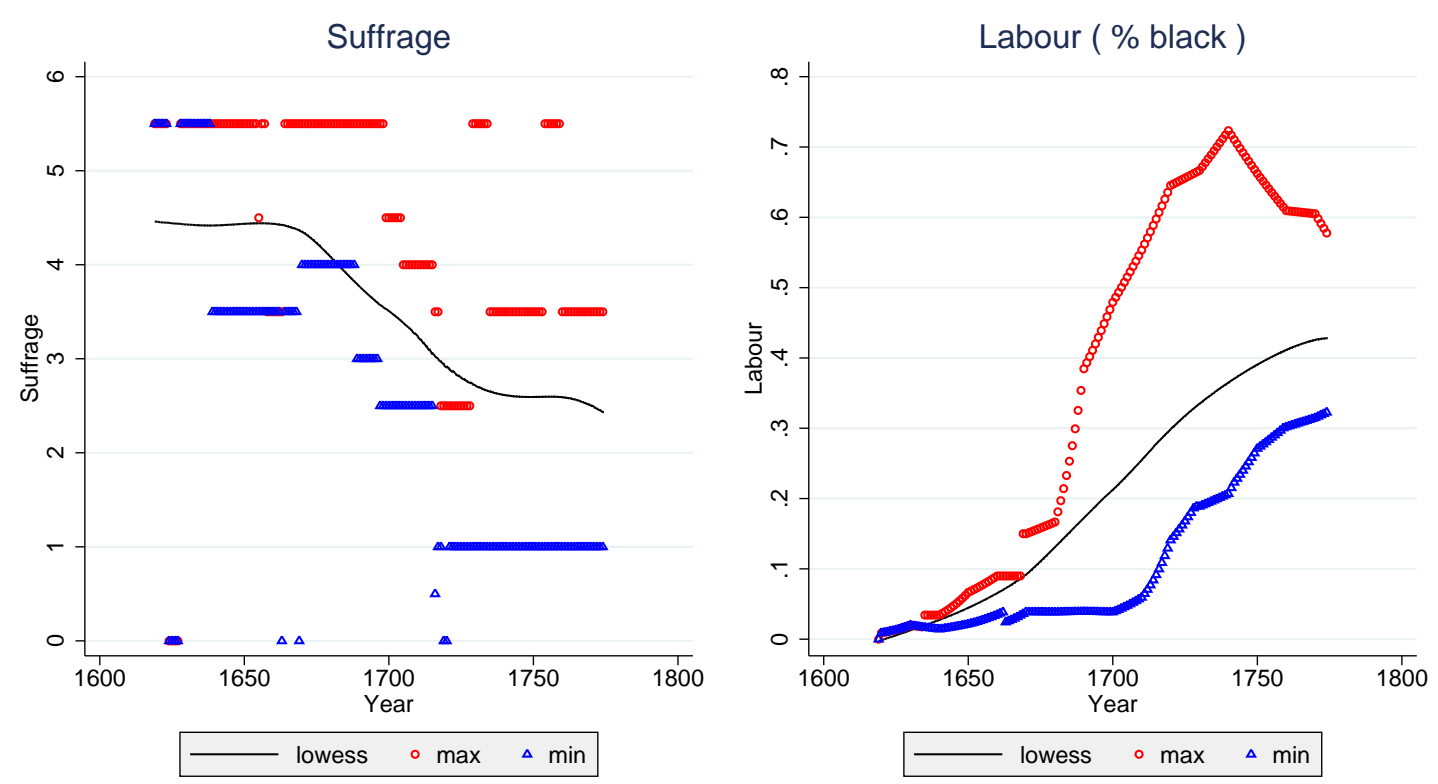

(b) Northern colonies
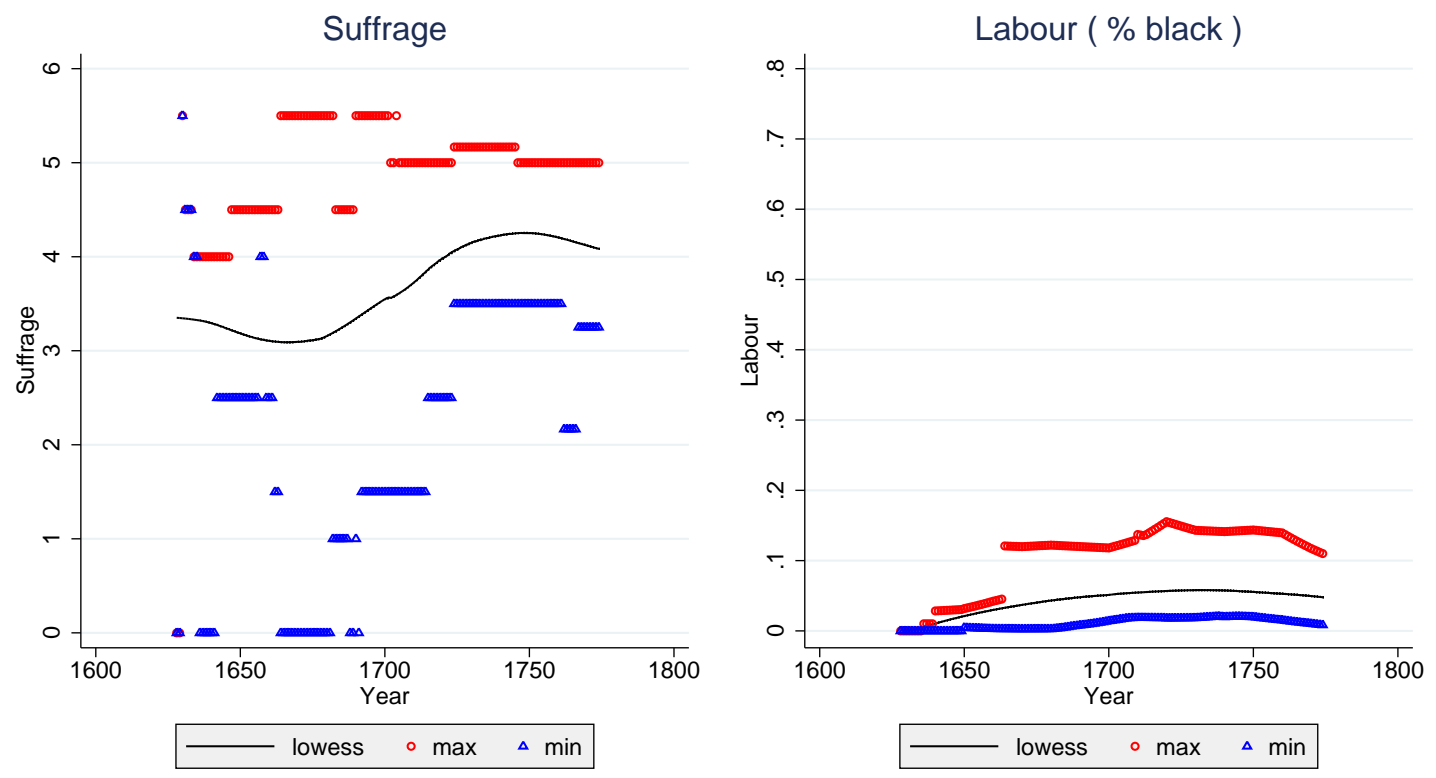

Sources: See text. Notes: This graph shows how suffrage and labour markets evolved over time in the northern and southern colonies. A higher value of suffrage indicates a more liberal political system. The black lines are obtained by locally weighted least squares smoothing (lowess) over all colony-year observations. For each year, each graph presents three data points: the maximum value of the suffrage or percent black variable observed across all colonies in the region (red circle), the minimum value (blue triangle), and the value obtained using lowess smoothing (black dot). 
Figure 2: Suffrage, labour markets and inequality within the South

(a) Labour (\% black)

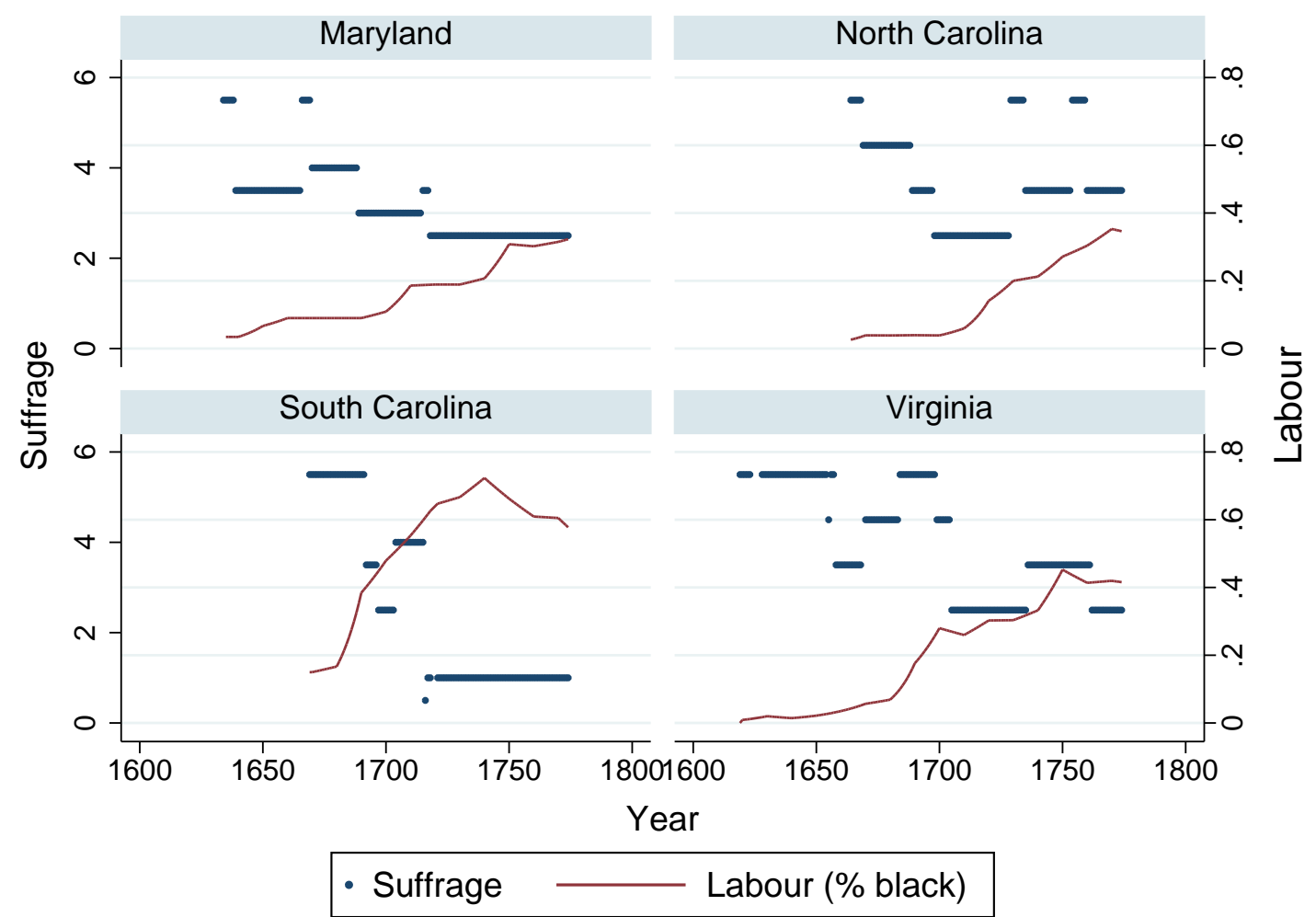

(b) Inequality (\% landless)

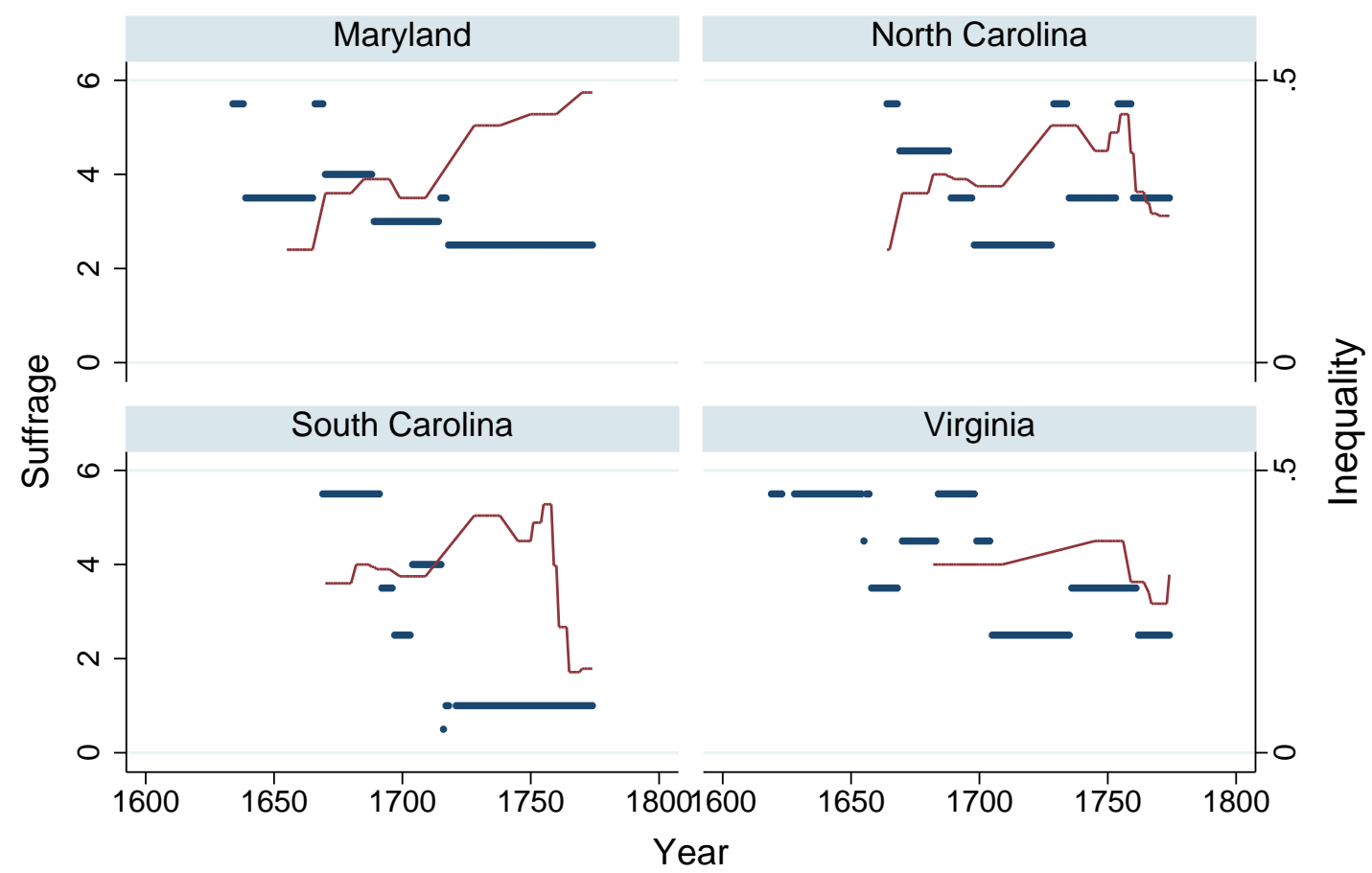

- Suffrage Inequality (\% white landless)

Sources: see text. Notes: This graph shows how suffrage, labour markets and inequality evolved over time for each of the Southern colonies. 
which each colony was proprietary or charter colony, with royal colony the omitted category); $\gamma_{t}$ is a year control; $\mu_{c}$ is a colony fixed effect; and $\varepsilon_{c t}$ is the disturbance term. All independent variables are lagged by one period (three years, see more details below). Since a higher value of suffrage implies better political institutions, I expect $\theta_{1}$ and $\theta_{2}$ to be negative. As the share of whites, relative to blacks, increases, and percentage white landless decreases (implying that inequality is lower), democratic institutions are more likely to emerge and survive. ${ }^{15}$

The data set uses an unbalanced time series cross-section that covers the years 1619-1774. I drop observations for the Northern colonies during Dutch or Swedish rule in order to avoid any confounding effects arising from the differing identity of the colonisers. I also do not include observations for the years 1775-1776, as the American Revolution was under way in this period. I furthermore exclude all the observations for Georgia, as Georgia was only established in 1732. To alleviate any concerns about selectivity, Table A3 presents regression results which include all excluded years and observations. Since political institutions are "sticky", I create three-year panels by taking three-year averages for all variables (results are similar when I use shorter or longer averages or an annual panel). I use robust standard errors as clustered standard errors are not accurate when the number of clusters is small, but also experiment with wild boostrapped errors following Cameron et al. (2008) in Table 3 to account for the small number of clusters and minimise serial correlation, and obtain very similar results. I capture the effect of permanent colonylevel differences, such as climate or geography, by including colony fixed effects, while controls for urbanisation, population density and the type of colonial settlement control for time-varying colonial characteristics.

\footnotetext{
${ }^{15} \mathrm{~A}$ wide suffrage may decrease population income differences through transfers to the poor. However, such an effect will be a long-term one and should not be present when inequality is lagged.
} 
Using a lagged dependent variable is important, since it not only controls for institutional persistence, but also removes serial correlation. Although there may be a bias when colony fixed effects are included together with the lagged dependent variable, Beck and Katz (2011) and Judson and Owen (1999) show that this bias is small when the number of time periods per item is more than 20 or 30 (in my case, it is nearly 40 periods per colony). Even so, in the robustness section I also obtain very similar results with the Arellano-Bond GMM estimator, suggesting that any fixed effects-lagged dependent variable bias is not a source of concern.

One concern about this econometric setup is that, by including colony fixed effects and a lagged dependent variable in the regressions, it may simply capture rapid responses to shifting circumstances very different from the historical events on which the paper focuses. To address this, in Table A6, I present results (1) without colony fixed effects; (2) without a lagged dependent variable; and (3) without both. While the coefficients on the labour variable are (unsurprisingly) several times stronger in the regressions without a lagged dependent variable, they are negative and highly significant in all specifications. Second, in the same table I also construct a ten-year panel, where all regression variables are averaged over ten years, rather than three, as in the baseline specification. Again, I obtain very similar results. I also supplement the econometric results with a detailed historical discussion of the underlying link between labour markets and suffrage in the colonies in the online Appendix (Part $4) \cdot .^{16}$

\section{Instrumental Variables approach}

While the developed theoretical framework posits that the composition of colonial labour markets has a direct effect on the suffrage, it is plausible that this relationship

\footnotetext{
${ }^{16}$ In a companion paper, I also focus on a historical examination of the evolution of political institutions in colonial Virginia (Anonymous, 2014).
} 
may be confounded by reverse causality, with political institutions affecting migration, and thus the future composition of labour markets. In addition, the share of each colony's black population may be endogenous to a variety of unobserved variables, such as differences in colonial leaders.

I address these concerns by instrumenting labour markets with a crop suitability index (crop index), calculated as follows. For each colony, I collect data on its (fixed) propensity to produce one of the two labour intensive colonial export crops (tobacco and rice). I compile the same information for wheat, which can be grown in virtually any climate without significant amounts of labour. I interact each colony's suitability for rice and tobacco with their respective colonial prices, which change over time, and divide this sum by the suitability of each colony to produce wheat interacted with its price (I take the logarithm of the final quantity). The instrument therefore measures each colony's revenue earning potential for tobacco and rice, relative to that of wheat. ${ }^{17}$ Changes in the instrument within colonies are thus driven purely by price shocks to the three crops, while cross-colony differences could also arise because of differing crop suitabilities across colonies. Figure A10 plots the variation in the instrument for each of the colonies included in the analysis.

The logic behind the IV is as follows. Once the prices for tobacco and rice increase, landowners located in colonies which are suitable for producing the labourintensive crops will seek to acquire additional labour. If the supply of English indentured servants is inelastic (as was the case in the late 17th and early 18th centuries), those farmers will turn to slaves, leading to an increase in the share of the black population. Although I do not have data on the export price of these three commodities during the time period in question, historians point out that the colonies were largely price takers (Purvis, 1999; Kulikoff, 1986), so it is unlikely that the prices used in the construction of the IV were endogenous to colony-level factors. I discuss in more

\footnotetext{
${ }^{17}$ Cotton production did not start in the South until after the Revolution.
} 
detail the exclusion restrictions of the IV in the next section.

I obtain the crop price data from Purvis (1999) and Historical Statistics of the United States, Millennial Edition Online (2006). I compile the fixed crop suitability weights from the Food and Agriculture Organization of the United Nations Global Agro-Ecological Zones (GAEZ) 2010 database (FAO, accessed April 5, 2012). Although the latter data are not available historically, this should be a minor concern, as climate and soil conditions likely changed very little in the United States since colonial times. For each cell of approximately 56 by 56 kilometers, FAO combined information on the physical environment and the requirements for growing 154 crops, assuming different levels of input use and crop management. I make use of the premade crop summary tables, which provide crop suitability and potential yield data for each of the American states. Similarly to Nunn and Qian (2011), I define land to be suitable for either tobacco or rice if it yields at least 40 per cent of the maximum possible yield for these crops. I also assume that cultivation occurs under rain-fed conditions (as mechanical irrigation did not become popular in the US until after the Revolution), and low input intensity. ${ }^{18}$

\section{Results}

Table 1 reports OLS and IV estimates for equation (1), using four different specifications. First, the table shows that there is a negative relationship between the share of each colony's black population and the suffrage index, both in column (1), which excludes colony fixed effects and inequality, and in column (2), which presents the full specification. In fact, the coefficient on labour markets in column (2) is higher

\footnotetext{
${ }^{18}$ Nunn and Qian $(2011,609-610)$ and Easterly (2007) provide additional information on how these data were constructed. Results using the 20-percent and 60-percent yield cutoffs are similar but weaker, and assuming medium output intensity does not change the estimates.
} 
than that in column (1), with inequality having, as hypothesised, a negative effect on the quality of political institutions that is significant but nearly two times weaker than that of labour markets. In addition, the impact of labour markets on the suffrage is quantitatively important. A 10 p.p. increase in percentage black leads to a decrease in the suffrage index of approximately 0.159 restrictions, or close to $4.4 \%$, relative to the sample mean. Because I am also controlling for the lagged value of the suffrage index, it is more appropriate to consider the long-run effect of labour markets: a 10 p.p increase in percentage black leads to a decrease in suffrage of roughly 0.773 restrictions, or $21.2 \% .^{19}$

Column (3) instruments labour market composition with the crop index variable. The coefficient on percent black is still negative and significant, and its magnitude is nearly 1.6 times stronger than that in the OLS specification. As argued earlier, since percentage black is calculated using population data, rather than labour force estimates, it likely measures the composition of colonial labour markets with error. If this measurement error is classical, its coefficient in the OLS regressions may be biased downward.

In the final column of Table 1, I restrict the sample to only those observations that have a value of inequality (percentage landless) above the median value in the sample. The negative and significant relationship between the share of each colony's black population and the suffrage index survives even when inequality is kept constant in this sample of year-colonies with unequal incomes, which makes it less likely that percent black is simply a proxy for economic inequality.

The results in Table 1 also suggest that variables such as urbanisation, population density, and differences in colonial settlement patterns have limited impact on the quality of colonial political institutions. Unreported estimates in which urbanisation

\footnotetext{
${ }^{19}$ The cumulative effect is calculated by dividing the coefficient on labour by the quantity (1coefficient on lagged suffrage) (column 2).
} 
Table 1: Suffrage in the 13 colonies: Main specification

\begin{tabular}{|c|c|c|c|c|}
\hline & $\begin{array}{l}(1) \\
\text { OLS }\end{array}$ & $\begin{array}{c}(2) \\
\text { OLS }\end{array}$ & $\begin{array}{c}(3) \\
2 \mathrm{SLS}\end{array}$ & $\begin{array}{c}(4) \\
\text { OLS } \\
\text { Inequality } \\
\text { above median }\end{array}$ \\
\hline Lagged Suffrage & $\begin{array}{c}0.785^{* * *} \\
(0.0429)\end{array}$ & $\begin{array}{c}0.794^{* * *} \\
(0.0405)\end{array}$ & $\begin{array}{c}0.769^{* * *} \\
(0.0529)\end{array}$ & $\begin{array}{c}0.773^{* * *} \\
(0.0637)\end{array}$ \\
\hline Labour (\%black) & $\begin{array}{c}-\mathbf{1 . 1 4 9}^{\text {****}} \\
(0.226)\end{array}$ & $\begin{array}{c}-\mathbf{1 . 5 9 3}^{\text {*** }} \\
(0.505)\end{array}$ & $\begin{array}{c}-\mathbf{2 . 6 0 8} \\
(1.324)\end{array}$ & 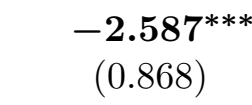 \\
\hline Inequality (\%white l.less) & & $\begin{array}{c}-0.683^{* *} \\
(0.321)\end{array}$ & $\begin{array}{c}-0.691^{* *} \\
(0.316)\end{array}$ & $\begin{array}{c}1.620 \\
(1.122)\end{array}$ \\
\hline Urbanisation & $\begin{array}{c}0.0478 \\
(0.172)\end{array}$ & $\begin{array}{c}0.161 \\
(0.235)\end{array}$ & $\begin{array}{c}0.140 \\
(0.223)\end{array}$ & $\begin{array}{c}0.838^{*} \\
(0.446)\end{array}$ \\
\hline Population density & $\begin{array}{c}0.00216 \\
(0.00552)\end{array}$ & $\begin{array}{c}0.00703 \\
(0.00623)\end{array}$ & $\begin{array}{c}0.00554 \\
(0.00621)\end{array}$ & $\begin{array}{c}0.00936 \\
(0.0131)\end{array}$ \\
\hline Year control & $\checkmark$ & $\checkmark$ & $\checkmark$ & $\checkmark$ \\
\hline Colony fixed effects & & $\checkmark$ & $\checkmark$ & $\checkmark$ \\
\hline Additional controls & $\checkmark$ & $\checkmark$ & $\checkmark$ & $\checkmark$ \\
\hline $\begin{array}{l}\text { Observations } \\
\text { Mean suffrage } \\
R^{2}\end{array}$ & $\begin{array}{r}491 \\
3.618 \\
0.766\end{array}$ & $\begin{array}{r}412 \\
3.633 \\
0.843\end{array}$ & $\begin{array}{r}412 \\
3.633 \\
0.842\end{array}$ & $\begin{array}{l}206 \\
3.446 \\
0.840\end{array}$ \\
\hline $\begin{array}{l}\text { First-Stage Results } \\
\text { Instrument Coefficient } \\
1^{\text {st }} \text { stage } R^{2}\end{array}$ & & & $\begin{array}{l}0.320^{* * *} \\
(0.046) \\
0.924\end{array}$ & \\
\hline
\end{tabular}

Sources: see text. Notes: This table shows results from OLS and 2SLS regressions explaining the suffrage in the 13 British American colonies. The data set is obtained by taking threeyear averages for each colony. Column 4 only uses those colony-year observations with above median inequality. Independent variables are lagged by one period (three years). Additional controls include a dummy for when each colony was proprietary or charter (with royal as omitted category). A linear trend is used as "Year control". Robust standard errors are in parentheses. ${ }^{* * *} p \leq 0.01,{ }^{* *} p \leq 0.05,{ }^{*} p \leq 0.1$. 
and population density were entered separately, rather than together produced very similar results. In estimations which are available upon request, I also allowed inequality to vary non-linearly, which did not produce significant coefficients on the higher-order inequality terms and had little effect on the overall results.

Table 2 shows that the results in Table 1 are robust to using alternative measures of labour markets. Columns (1) to (3) substitute the share of each colony's black population with a binary variable that is 1 for the South after 1700, and 0 for all other colonies and years. ${ }^{20}$ Although crude, a significant relationship between this variable and the suffrage index should alleviate concerns that the labour markets-suffrage relationship is driven by something idiosyncratic in the percentage black measure. Not surprisingly, the coefficient estimates are significant, albeit much weaker than those in Table 1.

In columns (4)-(5), I use Caribbean slave prices as a measure of labour market structure. Since the Caribbean was the largest slave market throughout the colonial period which set prices for the rest of the New World, high Caribbean slave prices should decrease the demand for - and the number of - new slaves in the South. The expected relationship between this measure of labour markets and the suffrage index is therefore positive. I prefer to use Caribbean slave prices instead of prices in North America, as the latter are likely endogenous to domestic demand.

Because the number of slaves in the North was very small, it is likely that Northern slave-owners obtained black labourers from a different market, and at different prices, than those in the South. ${ }^{21}$ Unfortunately, I do not have data on Northern

\footnotetext{
${ }^{20}$ Using alternative years for the cutoff $(1690,1695,1705$, and 1710) did not change the results.

${ }^{21}$ Although there were some slaves in the Northern colonies, they were very few and had little economic significance. They did not come directly from Africa, but were either unwanted blacks from the Caribbean or the South, or those captured by privateers or pirates operating from the northern ports. Such slaves were "[b]roken, enfeebled and generally unfit for plantation labor," and "found their way to northern ports when no one else would purchase them" (Berlin, 1998, 47-48).
} 
Table 2: Suffrage in the 13 colonies: alternative measures of labour markets

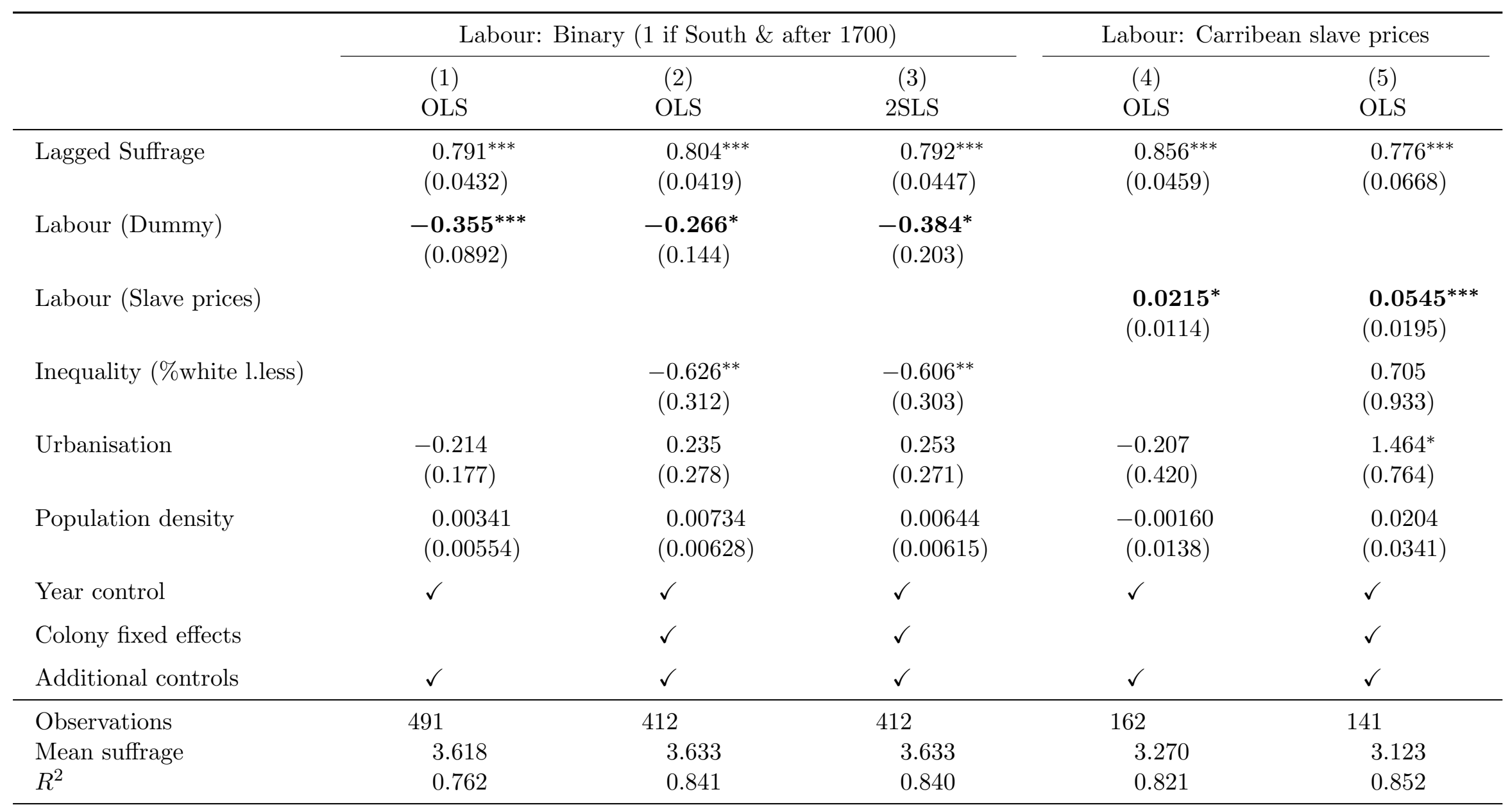

$\begin{array}{lc}\text { First-Stage Results } & \\ \text { Instrument Coefficient } & 2.170^{* * *} \\ & (0.126) \\ 1^{\text {st }} \text { stage } R^{2} & 0.909\end{array}$

Sources: See text. Notes: This table shows results from OLS and 2SLS regressions explaining the suffrage in the 13 British American colonies, where labour is measured as a binary indicator ( 1 for the South after 1700, and 0 for all other colony-year observations), and as Caribbean slave prices (with the sample restricted only to the South; columns 4-5). The data set is obtained by taking three-year averages for each colony. All independent variables are lagged by one period (three years). A linear trend is used as "Year control". Additional controls include a dummy for when each colony was proprietary or charter (with royal as omitted category). Robust standard errors are in parentheses. ${ }^{* * *} p \leq 0.01,{ }^{* *} p \leq 0.05,{ }^{*} p \leq 0.1$. 
slave prices, so I need to restrict my analysis only to colonies in the South. Moreover, the small sample size prevents me from conducting the IV analysis in this specification. Despite these caveats, the coefficient on Caribbean slave prices is - as expected - positive and significant. The estimates in column (5) imply that a one standard deviation increase in the price of a single slave improves the suffrage index in the South by around 0.420 restrictions, or approximately $13.4 \%$ relative to the sample mean in the short run. ${ }^{22}$

I test the robustness of these results in Table 3 below, as well as in Tables A3-A7 in the online Appendix. First, in Table 3 I include colony-specific trends, in addition to the colony fixed effects, (columns (1) - (2)). The labour coefficient is slightly smaller in magnitude but still significant, while inequality loses significance. Results are similar when I instead use regional trends (columns (3)-(4)). In column (5), I use an annual panel to calculate the standard errors using the wild boostrap method of Cameron et al. (2008), which is a more appropriate way for modeling withincolony correlation of the errors when the number of clusters is small, as compared to the conventional clustered errors method. Results are analogous to those presented earlier, and also survive when I experiment with other unreported specifications of the errors, such as a Prais-Winsten regression, clustered standard errors, NeweyWest standard errors (with one, two or three lags), panel corrected standard errors (PCSEs) following Beck and Katz (2011), and the inclusion of an additional lag of the dependent variable. The last column in Table 3 implements the ArellanoBond GMM regression to account for the possible bias arising from the simultaneous inclusion of colony fixed effects and a lagged dependent variable. The coefficient on percent black is again negative and significant.

In the online appendix, I present and discuss several additional robustness tables,

\footnotetext{
${ }^{22}$ The mean Caribbean slave price during this period was around 27.4 pounds sterling, with a standard deviation of 7.7 .
} 
which again preserve the main results. Tables A3 and A4 experiment with various aggregations of the dependent variable, as well as regressions with an annual panel. Table A5 instead investigates the impact of ethnic and religious fractionalisation on the suffrage, and the role of the Scotch-Irish migration of 1717-1775 (see more discussion on the latter below). Table A6 shows that the baseline results survive when I drop the colony fixed effects, the lagged dependent variable and when I use a ten-year average panel. Table A7 replicates the results in Table 1 but without including inequality.

\section{IV validity and exclusion restrictions}

The adopted IV strategy would be valid provided that three conditions are satisfied. First, the empirical analysis above illustrates that the relationship between the instrument and the share of each colony's black population is indeed strong, with F-statistics significantly above 10. Moreover, the effect of crop index on the suffrage must work only through labour markets. More precisely, the IV should not affect the dependent variable directly, or through variables omitted from the model. I examine the validity of each of these assumptions below.

Could the crop index variable have a direct effect on political institutions? For example, a rise in the prices of labour intensive crops will make farmers expand production, and consequently increase their demands for labour. If slaves are unavailable, planters will respond by liberalising the suffrage, and thus the crop index might affect the suffrage directly, even if the share of blacks is constant. However, the evolution of tobacco, rice and wheat prices (Figures A11a, A11b and A11c) reveals that the only crop whose prices might justify a direct link between crop index and the suffrage is tobacco, as its prices rose rapidly during the period 1647-1675. Even so, tobacco planters would have been ambivalent about attracting additional labour, as this upward surge was volatile and relatively short-lived. Indeed, when 
Table 3: Suffrage in the 13 colonies: Robustness checks 1

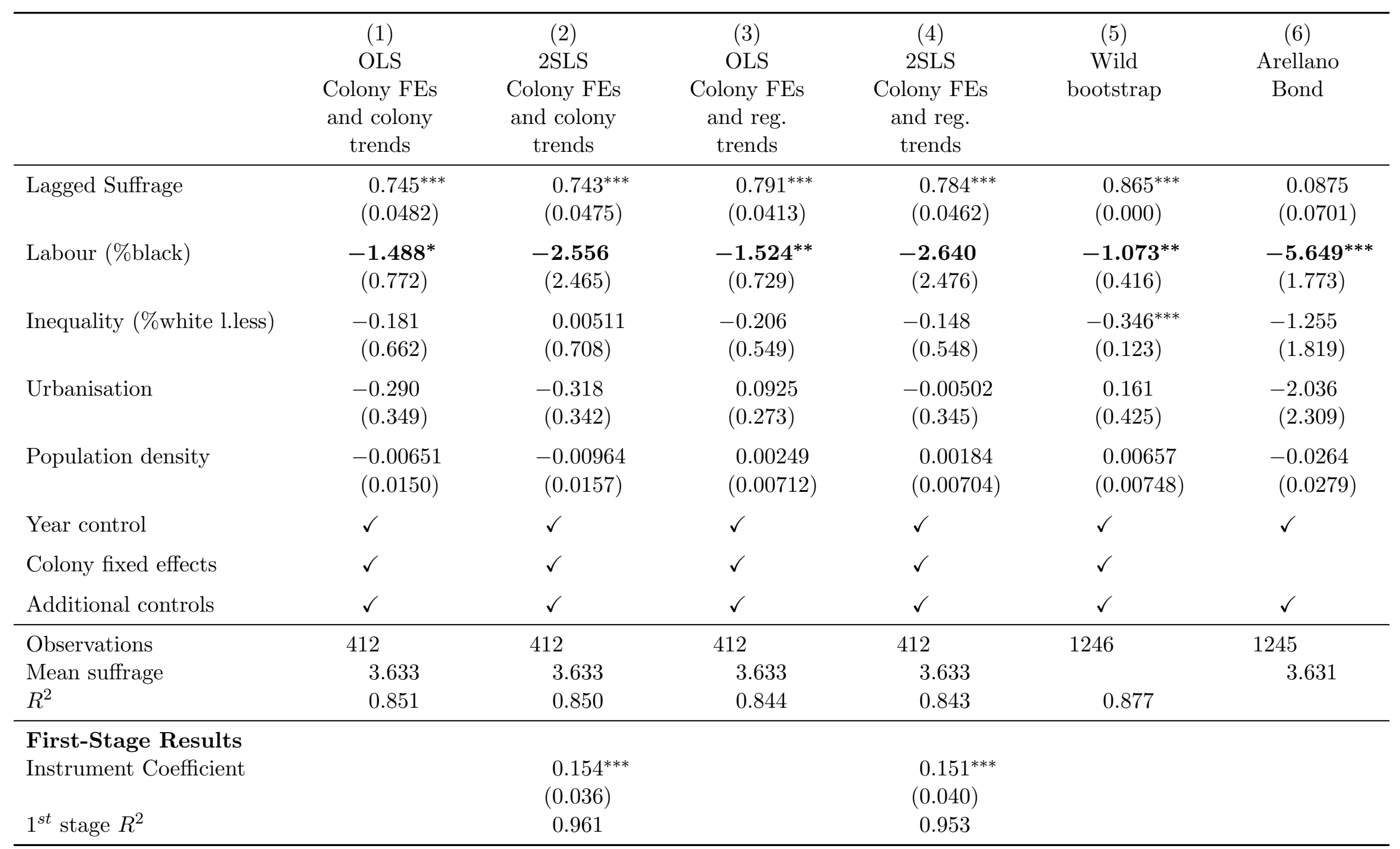

Sources: See text. Notes: This table shows results from OLS and 2SLS regressions explaining suffrage in the 13 British American colonies (robustness checks). The data set used in columns 1 - 4 is obtained by taking three-year averages for each colony. Columns 5 and 6 use annual data. All independent variables are lagged by one period (three years for column 1 - 4 and one year for columns 5 and 6 ). A linear trend is used as "Year control". Additional controls include a dummy for when each colony was proprietary or charter (with royal as omitted category). Robust standard errors are in parentheses. ${ }^{* * *} p \leq 0.01,{ }^{* *} p \leq 0.05,{ }^{*} p \leq 0.1$. 
I drop from the regressions all years until 1675, the (unreported) results are nearly identical to those presented in Table 1.

A second concern is that the instrument may be correlated with other determinants of the dependent variable, either observed or unobserved. First, the crop index may simply capture differences in persistent factor endowments and economic inequality across colonies, as argued by Engerman and Sokoloff $(2000,2002,2005)$. There are at least three reasons that mitigate this concern. First, the inequality variable included in the regressions (percent landless) should capture at least some of the variation in the colonial income distribution. Moreover, the inclusion of colony fixed effects ensures that the effect of the instrument is not confounded by colonyspecific fixed variables. Third, by combining price and crop suitability data, the crop index provides information on each colony's revenue earning potential for tobacco and rice, compared to that of wheat, without making a statement about the relative distribution of these crop revenues. This is also confirmed by the unconditional correlation between crop index and inequality and the sample (0.250), which is not overwhelming enough to raise concern.

Alternatively, the effect of the instrument on the suffrage could work through some omitted variable from the model. The very low correlation between the instrument and the regression residuals (less than 0.00001), the inclusion of colony fixed effects and time dummies, as well as the multiple robustness tests performed in the previous section and in the online Appendix suggest that this is less likely to be the case. Table A8, which further experiments with dropping (1) colony fixed effects; (2) urbanisation and population density; and (3) urbanisation, population density and inequality from the IV specification, also shows that the coefficient on labour (percent black) remains remarkably stable across specifications, thus pointing away from the role of unobservables.

Still, one possibility is that a rise in crop prices may also increase overall welfare, 
which in turn may directly affect the emergence and stability of political institutions. On one hand, as government revenues (largely based on crop export duties) grow and the costs of redistribution are partially offset, elites may be more likely to extend the suffrage. On the other hand, long-term rises in income per capita may lead to attitudinal changes in the population that make a democratic regime more likely to emerge and to be sustained. ${ }^{23}$ Although some of these effects should be captured by the controls for urbanisation and population density included in the regressions, these are admittedly less precise than a direct measure of income per capita, which unfortunately does not exist. An examination of one available income proxy for colonial Maryland, a welfare ratio calculated by Allen et al. (2012), in fact provides some suggestive evidence against these hypotheses. In fact, the disfranchisement of landless whites in Maryland in the early eighteenth century was accompanied by a welfare ratio which was rising, rather than falling. ${ }^{24}$

I conclude that, in line with Hypothesis 1, there is a consistent negative relationship between the share of each colony's black population and the colonial suffrage. I also find support for Hypothesis 2. Inequality has a negative impact on the quality of colonial political institutions, but the magnitude of the effect is several times smaller than that of labour markets. In the next section, I discuss three potential validity concerns which may threaten the reliability of these estimates. I elaborate more on the role of (1) the Scotch-Irish migration wave of 1717-1775; and (2) racially motivated conflicts in the online Appendix (Part 2).

\footnotetext{
${ }^{23}$ See, for instance, Limongi and Przeworski (1997), as well as Boix (2011).

${ }^{24}$ The welfare ratio is the full-time, full-year earnings of a male unskilled worker relative to the cost of subsistence for a family of four. A welfare ratio of 1 indicates that the labourer earns just enough to keep his family at subsistence, while values greater than 1 mean that the family could afford additional items.
} 


\section{Alternative explanations}

The theoretical mechanism outlined above provides one reason why we may observe a connection between the composition of colonial labour markets and the quality of political institutions. Still, there may be several alternative explanations for this finding that I review below.

\section{The relationship between inequality and labour market com- position}

An important concern about the validity of the empirical results is the potential relationship between labour market structure (proxied by percentage black) and inequality (proxied by percentage white landless). If percentage black simply captures the spread of plantation agriculture and thus increasing income inequality in the South, as compared to the North, the presented results will be spurious. Although I attempt to address this concern by including a control for income inequality in all regressions, it is plausible that the only available inequality proxy that I have (the percent of each colony's white landless population) is less precise than a more direct measure (such as a Gini coefficient).

Although detailed income inequality statistics for colonial America are unavailable, the existing evidence shows that the relationship between inequality and slavery during this time period is not clear-cut. This is not surprising, as large Southern landowners were able to amass significant fortunes, as compared to indentured servants, even before slaves became widely available. In a companion paper (Anonymous, 2014), I trace the evolution of income inequality in Virginia from the early seventeenth century until the American revolution, using a variety of sources such as land transfer records, wills, height data, and the distribution of slave holdings to show that slavery benefited equally both small and large farmers, and that income 
inequality in the colony did not increase substantially in the eighteenth century. What is more, data in Jones (1980) demonstrate that, on the eve of the American Revolution, the wealth distribution in New England was actually more unequal than that in the South. In 1774, the richest 10 per cent of people who left probate records held 57 per cent of the net worth in New England, compared with 49 per cent in the South and 42 per cent in the Middle colonies.

Even so, it is instructive to investigate the relationship between percent white landless and percent black in my data set. If the arrival of slavery increased inequality because it gave the rich an opportunity to establish large plantations, then such a relationship should be particularly pronounced in the Southern colonies. Graphical evidence shows that there is a weak relationship between inequality and labour in the South (the correlation for the whole region is 0.160; see Figures A11 and A12). ${ }^{25}$ Although the unconditional correlation between inequality and labour in the full sample is somewhat higher than that in the South (0.322), a regression analysis shows the lack of a relationship between the two variables (Figure A13).

\section{The threat of revolution}

A second explanation predicts that elites will extend the right to vote to the masses in order to credibly commit themselves to economic concessions in the face of organised mass resistance (Acemoglu and Robinson, 2006; Jack and Lagunoff, 2006). However, several reasons weaken the conclusion that Southern elites implemented a restrictive political regime which favoured the land holding class only after revolutionary threats from the masses subsided in the early eighteenth century.

\footnotetext{
${ }^{25}$ Regressing (for the South only) inequality on its lagged value, labour, urbanisation, population density, controls for colonial settlement patterns, and year and colony fixed effects produced a significant but very weak relationship, in which one percentage point increase in percent black leads to 0.0005 percentage points increase in inequality.
} 
In Virginia, a series of rebellions in the period 1660-1683 - such as the servant uprising of 1663, Bacon's rebellion in 1676, and the tobacco cutting riots of 1683 included poor whites and indentured servants who protested against their gradual loss of political rights (Breen, 1973). However, subsequent gains in the franchise were short-lived. For example, the 1676 decision to extend the suffrage to all freemen (rather than only freeholders) was rescinded in the same year, and only freeholders and householders could vote until 1683. Although after 1684 a new wording of the law did not prohibit landless freemen from voting and contained no punishment for irregular voting, essentially allowing all freemen to vote, this law was repealed in 1698, again granting the suffrage to only freeholders (McKinley, 1905).

What is more, Virginia's most liberal political institutions were adopted in the early seventeenth century, at a time when there were in fact few uprisings. More importantly, it was the switch from indentured servitude to slaves in the early eighteenth century that prompted whites to view blacks as the main threat to the colony's tranquility, thus underlying Virginia's stability (Breen, 1973, p.13-16). What is key, however, is that the shift to slavery also drove the tightening of the franchise in eighteenth-century Virginia. As Anonymous (2014) shows, slavery benefited not only large planters, but also smaller farmers who could afford even a few slaves. As the latter class expanded and prospered and the number of indentured servants and poor whites dwindled, the interests of big and small landholders became more closely aligned. This not only prompted the restriction of the suffrage to freeholders in 1699, but also made it increasingly costly for small farmers to participate in lower class collective action, which improved the security situation in the colony.

Evidence from other colonies further questions the idea that colonial representative institutions were driven by revolutionary threats. In Maryland and the Carolinas, uprisings reflected disagreements within the elite as well as religious tensions, rather than franchise considerations. For instance, in the 1680s, opposers of Mary- 
land's proprietary government cited a list of grievances, such as Lord Baltimore's appointment of his relatives for public offices; proprietary appointment of sheriffs; excessive fees and taxes; as well as anti-Catholic sentiments against the proprietors by the Protestant colonists. The property requirement for voting set in 1670 was also mentioned, but colonists complained about the fact that it was set by the proprietor, rather than the legislature (Ward, 1991, p. 259-262). In North Carolina, the 1677 Culpeper rebellion sought to stop payment to England of customs duties on exported tobacco, while Cary's rebellion (in 1704) resulted from a contest over the office of deputy governor (Ward, 1991, p. 263-264). In South Carolina, political instability was rooted in disagreements between the proprietors and an anti-proprietary faction. In 1690, Seth Sothel, backed by nearly five hundred people, staged a coup against the proprietor, while in 1719 there were clashes between the Assembly and the proprietor motivated by the desire of the colonists to overthrow proprietary rule (Ward, 1991, p. 264-265). In New England and New York, the Glorious Revolution in England prompted uprisings in Boston and New York City. Although in Massachusetts, a property basis of the suffrage replaced the earlier religious qualifications, the franchise still remained rather restrictive (McKinley, 1905). There were no changes to political institutions in New York. In sum, a possible link between representative institutions and changing revolutionary threats is less than clear.

\section{The importance of culture}

In this subsection, I examine whether differences in migrants' cultural backgrounds affected the quality of colonial political institutions, and, in particular, whether colonies with a wide franchise had a majority of inhabitants coming from more politically liberal European countries.

There is little data on the country of origin of each colony's population until the first US census conducted in 1790. What we do know, however, is that by 1680 , 
nearly $90 \%$ of colonial Americans were English, and that by the early eighteenth century, more and more non-English migrants were arriving in the colonies, with the largest groups including Scotch-Irish, Germans and Dutch (Ward, 1991, p. 109-116). An argument emphasising the importance of culture, however, is less compelling, for at least three reasons.

First, no European settler experienced a suffrage as broad as the one granted in the Southern colonies. In England, the forty-shilling freehold requirement excluded nearly $98 \%$ of adult males (Acemoglu and Robinson, 2012), while in the Habsburg empire, no popular parliament existed, as Habsburg family members were routinely elected to the office of Holy Roman Emperor by seven hereditary electors. Similarly, although the Dutch republic had a relatively strong federal parliament (the States General) and a weak executive by the standards of late medieval and early modern period, popular political participation was limited. Members of the States General were selected by the provincial parliaments, selection for which was in turn limited to a list of regential families (Congleton, 2010). ${ }^{26}$

Second, any cross-colony cultural differences which were either fixed over time or followed linear time trends specific to each colony should be captured by the inclusion of colony fixed effects (present in most regressions) as well as colony time trends (see Table 3). Of course, it is possible that the rate of in-migration of particular groups was non-linear. For instance, the arrival of large numbers of Scotch-Irish settlers in the South in 1717-1775 may have been behind the decision of colonial elites to tighten the franchise. These migrants came from "lawless" regions in Britain on the border with Ulster, and were considered to be more violent and less hard-working than the Germans or the Dutch (Sowell, 2013). I examine this possibility empirically

\footnotetext{
${ }^{26}$ Only one Dutch province differed from this model: in Friesland, all owners of particular real properties (without a minimum value requirement) could participate in local (county) elections which led to provincial representation (personal communication with Jan de Vries, April 7, 2014).
} 
in the online Appendix (Table A5) and find little support for it.

\section{Conclusion}

Why do elites choose to extend the suffrage to the masses? Using detailed data from the thirteen British American colonies, this paper proposes one answer to this question: elites may wish to extend the right to vote to the lower classes in order to attract migrant workers. I develop a theory in which a representative assembly serves as a commitment device for any promises made to labourers by those in power, such as those related to compensation, labour contracts, or the allocation of land grants. While the theory also accommodates a negative relationship between income inequality and the extent of the franchise (as argued by earlier literature), an examination of both quantitative and historical evidence reveals a weaker and less robust impact of income inequality.

I test the theory by analysing a new time series cross-section data set from colonial British America covering more than 150 years. Colonial governments enforced a liberal franchise only in those colonies that relied on white workers, such as the seventeenth century South and the North, and immediately rescinded political concessions once white labourers could be substituted with black workers, as in the South after the arrival of slavery. To rule out alternative explanations, I construct a new instrument for the composition of colonial labour markets, experiment with several different measures of labour markets, control for a wide range of variables, including income inequality, and include colony fixed effects in all specifications.

My work helps identify the specific conditions under which institutions can be malleable and under which they persist, a fundamental research and policy question about which we still know relatively little. By emphasising the link between the quality of labour and that of political institutions, the paper suggests that democracy 
is less likely to emerge and survive in countries where economic production relies on easily replaceable, low-skill workers who have limited bargaining power vis-a-vis the ruling politicians. Shedding light on where such differences in labour markets come from, both across space and throughout history, may therefore be crucial for understanding how democracies originate and evolve. 


\section{References}

Acemoglu, D., C. García-Jimeno, And J. A. Robinson (2012): "Finding Eldorado: Slavery and Long-Run Development in Colombia," Journal of Comparative Economics.

Acemoglu, D., S. Johnson, And J. A. Robinson (2001): "The Colonial Origins of Comparative Development: An Empirical Investigation," American Economic Review, 91, 1369-1401.

Acemoglu, D. And J. Robinson (2012): "Why Nations Fail: Origins of Power, Poverty and Prosperity," .

Acemoglu, D. And J. A. Robinson (2006): Economic Origins of Dictatorship and Democracy, Cambridge University Press.

Albouy, D. Y. (2012): "The colonial origins of comparative development: an empirical investigation: comment," The American Economic Review, 102, 30593076 .

Alesina, A., R. BaqIR, And W. Easterly (1999): "Public goods and ethnic divisions," The Quarterly Journal of Economics, 114, 1243-1284.

Allen, R. C., T. E. Murphy, And E. B. Schneider (2012): "The Colonial Origins of the Divergence in the Americas: A Labor Market Approach," The Journal of Economic History, 72, 863-894.

AnONymous (2014): "Suffrage, labour markets and commitment: evidence from colonial Virginia," .

Ansell, B. And D. SAmuels (2010): "Inequality and democratization: A contractarian approach," Comparative Political Studies, 43, 1543-1574.

Atkinson, A. B. And A. Brandolini (2001): "Promise and Pitfalls in the Use of "Secondary" Data-Sets: Income Inequality in OECD Countries as a Case Study," Journal of Economic Literature, 39, 771-799.

Beck, N. And J. N. Katz (2011): "Modeling Dynamics in Time-Series-CrossSection Political Economy Data," Annual Review of Political Science, 14, 331-352.

Berlin, I. (1998): Many Thousands Gone: The First Two Centuries of Slavery in North America, Harvard University Press.

Bertocchi, G. And C. Strozzi (2008): "International Migration and the Role of Institutions," Public Choice, 137, 81-102.

Boix, C. (2003): Democracy and Redistribution, Cambridge University Press. (2011): "Democracy, Development, and the International System," American Political Science Review, 105, 809-28. 
Bourguignon, F. And C. Morrisson (2002): "Inequality among world citizens: 1820-1992," American economic review, 727-744.

Braun, S. And M. Kvasnicka (2013): "Men, Women, and the Ballot: Gender Imbalances and Suffrage Extensions in the United States," Explorations in Economic History, 50, 405-426.

Breen, T. H. (1973): "A Changing Labor Force and Race Relations in Virginia 1660-1710," Journal of Social History, 7, 3-25.

Bruce, P. (1910): Institutional History of Virginia in the Seventeenth Century, G.P. Putnam's sons.

Cameron, A. C., J. B. Gelbach, and D. L. Miller (2008): "Bootstrap-Based Improvements for Inference with Clustered Errors," The Review of Economics and Statistics, 90, 414-427.

Chute, M. (1969): The First Liberty: A History of the Right to Vote in America, 1619-1850, Dutton.

Congleton, R. D. (2010): Perfecting Parliament, Cambridge University Press.

(2011): "Democracy in America: Labor Mobility, Liberalism, and Constitutional Reform1," .

CoOper, W. J. (2000): Liberty and slavery: southern politics to 1860, Univ of South Carolina Press.

Dinkin, R. J. (1977): Voting in Provincial America: A Study of Elections in the Thirteen Colonies, 1689-1776, Greenwood Press.

EAsterly, W. (2007): "Inequality Does Cause Underdevelopment: Insights from a New Instrument," Journal of Development Economics, 84, 755-776.

Easterly, W. And R. Levine (1997): "Africa's Growth Tragedy: Policies and Ethnic Divisions," The Quarterly Journal of Economics, 112, 1203-1250.

Einhorn, R. L. (2008): American Taxation, American Slavery, University of Chicago Press.

Eltis, D., F. D. Lewis, And D. Richardson (2005): "Slave Prices, the African Slave Trade, and Productivity in the Caribbean, 1674-1807," The Economic History Review, 58, 673-700.

Engerman, S. L. And K. L. SokolofF (2000): "History Lessons: Institutions, Factors Endowments, and Paths of Development in the New World," The Journal of Economic Perspectives, 14, 217-232.

(2002): "Factor Endowments, Inequality, and Paths of Development among New World Economies," Economía, 3, 41-109. 
- (2005): "The Evolution of Suffrage Institutions in the New World," Journal of Economic History, 65, 891.

FAO (accessed April 5, 2012): "FAO Global Agro-Ecological Zones (GAEZ) 2010 database," .

Fishback, P. (2006): "Social Insurance and Public Assistance," in Historical Statistics of the United States, Millennial Edition On Line, ed. by S. B. Carter, S. S. Gartner, M. R. Haines, A. L. Omstead, R. Sutch, and G. Wright, Cambridge University Press, 693-700.

Fleck, R. K. And F. A. Hanssen (2006): "The Origins of Democracy: A Model with Application to Ancient Greece*," Journal of Law and Economics, 49, 115146.

(2009): "Rulers ruled by women: an economic analysis of the rise and fall of womens rights in ancient Sparta," Economics of Governance, 10, 221-245.

(2013): "When voice fails: Potential exit as a constraint on government quality," International Review of Law and Economics, 35, 26-41.

Freeman, J. R. And D. P. Quinn (2012): "The Economic Origins of Democracy Reconsidered," American Political Science Review, 106, 58-80.

Galenson, D. W. (1996): "The Settlement and Growth of the Colonies: Population, Labor and Economic Development," The Cambridge Economic History of the United States, 1, 135-207.

Gleditsch, K. S. and M. D. Ward (2006): "Diffusion and the International Context of Democratization," International Organization, 60, 911.

Gray, L. And E. Thompson (1933): History of Agriculture in the Southern United States to 1860, vol. 2 of Carnegie Institution of Washington publication, Carnegie Institution of Washington.

GrubB, F. (2000): "The Statutory Regulation of Colonial Servitude: an IncompleteContract Approach," Explorations in Economic History, 37, 42-75.

GrubB, F. W. (1990): "Growth of literacy in colonial America: Longitudinal patterns, economic models, and the direction of future research," Social Science History, 451-482.

HagGard, S. And R. R. Kaufman (2012): "Inequality and regime change: Democratic transitions and the stability of democratic rule," American Political Science Review, 106, 495-516.

Hall, C. C. (1910): Narratives of early Maryland, 1633-1684, Scribner.

Harrold, S. (2001): The American Abolitionists, Pearson Education. 
Hening, W. W. (1819-1823): The Statutes at Large: Being a Collection of All the Laws of Virginia, from the First Session of the Legislature, in the Year 1619, R. \& W. \& G. Bartow.

Historical Statistics of the United States, Millennial Edition Online (2006): "Part E, Government and International Relations," in Colonial Statistics, Cambridge University Press, ed. by R. Sutch and S. Carter.

Houle, C. (2009): "Inequality and Democracy," World Politics, 61, 589-622.

JACK, W. AND R. LAGUnOfF (2006): "Dynamic enfranchisement," Journal of Public Economics, 90, 551-572.

Jones, A. H. (1980): Wealth of a Nation to Be: The American Colonies on the Eve of the Revolution, Columbia University Press.

Jordan, D. W. (2002): Foundations of Representative Government in Maryland, 1632-1715, Cambridge University Press.

Judson, R. A. And A. L. Owen (1999): "Estimating Dynamic Panel Data Models: a Guide for Macroeconomists," Economics Letters, 65, 9-15.

Kenny, L. (2004): "Votes for Women," in The Encyclopedia of Public Choice, ed. by C. Rowley and F. Schneider, Kluwer Academic Publishers Group.

Kenny, L. W. (1999): "Explaining the Puzzle of why Men Gave Women the Right to Vote," Working paper.

Keyssar, A. (2000): The Right to Vote: The Contested History of Democracy in the United States, Basic Books.

Kulikoff, A. (1986): Tobacco and Slaves: The Development of Southern Cultures in the Chesapeake, 1680-1800, University of North Carolina Press.

- (2000): From British Peasants to Colonial American Farmers, University of North Carolina Press.

Limongi, F. And A. Przeworski (1997): "Modernization: Theories and Facts," World Politics, 49, 155-183.

Lipset, S. M. (1959): "Some Social Requisites of Democracy: Economic Development and Political Legitimacy," American Political Science Review, 53, 69-105.

Lupu, N. And J. Pontusson (2011): "The structure of inequality and the politics of redistribution," American Political Science Review, 105, 316-336.

Main, J. T. (1965): The Social Structure of Revolutionary America, Princeton University Press. 
McKinley, A. E. (1905): The Suffrage Franchise in the Thirteen English Colonies in America, Ginn \& co., Boston.

Michener, R. W. (2003): "Money in the American Colonies," EH. Net Encyclopedia, Edited by Robert Whaples. URL http://eh. net/encyclopedia.

Moller, H. (1945): "Sex Composition and Correlated Culture Patterns of Colonial America," The William and Mary Quarterly, 2, 114-153.

Morgan, E. S. (1975): American Freedom, American Slavery: The Ordeal of Colonial Virginia, W. W. Norton, New York.

Nash, G. B. (1979): The Urban Crucible: Social Change, Political Consciousness, and the Origins of the American Revolution, Harvard University Press Cambridge, Mass.

North, D. C. And B. R. Weingast (1989): "Constitutions and Commitment: The Evolution of Institutions Governing Public Choice in Seventeenth-Century England," The Journal of Economic History, 49, 803-832.

Nunn, N. AND N. QIAn (2011): "The Potato's Contribution to Population and Urbanization: Evidence From A Historical Experiment," The Quarterly Journal of Economics, 126, 593-650.

OlasiJi, T. D. (1995): Migrants, Immigrants, and Slaves: Racial and Ethnic Groups in America, University Press of America.

Olson, M. (2000): Power and Prosperity: Outgrowing Capitalist and Communist Dictatorships, New York: Basic Books.

PANDE, R. AND C. UdRY (2005): "Institutions and Development: A View from Below," Proceedings of the 9th Congress of the Econometric Society.

Perry, R. AND J. CoOper (1959): Sources of Our Liberties: Documentary Origins of Individual Liberties in the United States Constitution and Bill of Rights, American Bar Foundation Series, New York University Press.

PritchetT, L. (1997): "Divergence, big time," Journal of economic perspectives, $11,3-18$.

Przeworski, A. (2009): "Conquered or granted? A history of suffrage extensions," British Journal of Political Science, 39, 291-321.

Purvis, T. L. (1999): Colonial America to 1763, Infobase Publishing.

Purvis, T. L. And R. Balkin (1995): Revolutionary America, 1763 to 1800, Facts on File.

Rabushka, A. (2002): "The Colonial Roots of American Taxation, 1607-1700," Policy Review, 114, 155-183. 
(2010): Taxation in Colonial America, Princeton University Press.

RAMCharan, R. (2010): "Inequality and Redistribution: Evidence from US Counties and States, 1890-1930," The Review of Economics and Statistics, 92, 729-744.

RAPER, C. L. (1904): North Carolina: a study in English colonial government, Macmillan Company: London, Macmillan \& Company, Limited.

Risch, E. (1937): "Encouragement of Immigration: As Revealed in Colonial Legislation," The Virginia Magazine of History and Biography, 45, 1-10.

Rosenbloom, J. (2008): "Indentured Servitude in the Colonial U.S." in EH.Net Encyclopedia, ed. by edited by Robert Whaples, .

Rusk, J. G. (2001): A Statistical History of the American Electorate, University of Chicago.

Salley, A. S. (1959): Narratives of Early Carolina, 1650-1708, Barnes \& Noble.

Smith, A. E. (1971): Colonists in Bondage: White Servitude and Convict Labor in America 160\%-1776, W. W. Norton, New York.

Sowell, T. (2013): Black Rednecks 83 White Liberals, Encounter Books.

Surrency, E. C. (1967): "The Courts in the American Colonies," The American Journal of Legal History, 11, 347-376.

United States Bureau of the Census (1975): Historical Statistics of the United States, Colonial Times to 1970, US Department of Commerce, Bureau of the Census, US Government Printing Office.

Vanhanen, T. (2002): Prospects of Democracy: A Study of 172 Countries, Routledge.

Villaflor, G. C. And K. L. Sokoloff (1982): "Migration in colonial America: Evidence from the militia muster rolls," Social Science History, 6, 539-570.

Ward, H. M. (1991): Colonial America, 1607-1763, Pearson College Division.

Weinberg, M. (2003): A Short History of American Capitalism, New History Press.

Wells, R. V. (1975): The Population of the British Colonies in America before 1776: A Survey of Census Data, Princeton University Press Princeton.

Welzel, C. and R. Inglehart (2007): "Mass Beliefs and Democratic Institutions," in The Oxford Handbook of Comparative Politics, Oxford University Press.

Wertenbaker, T. J. (1922): The Planters of Colonial Virginia, Princeton University Press.

West, R. C. (1978): "Money in the colonial American economy," Economic Inquiry, 16, 1-15. 


\section{Online Appendix (not for publication)}

This online appendix consists of four parts. Part 1 presents additional figures and tables. Part 2 presents additional robustness checks. Part 3 presents a detailed description of the data used in the regressions (to complement the discussion in the main text). Part 4 presents historical evidence. 
Part 1: Additional figures and tables 
Table A1: Summary statistics

Before 1700

After 1700

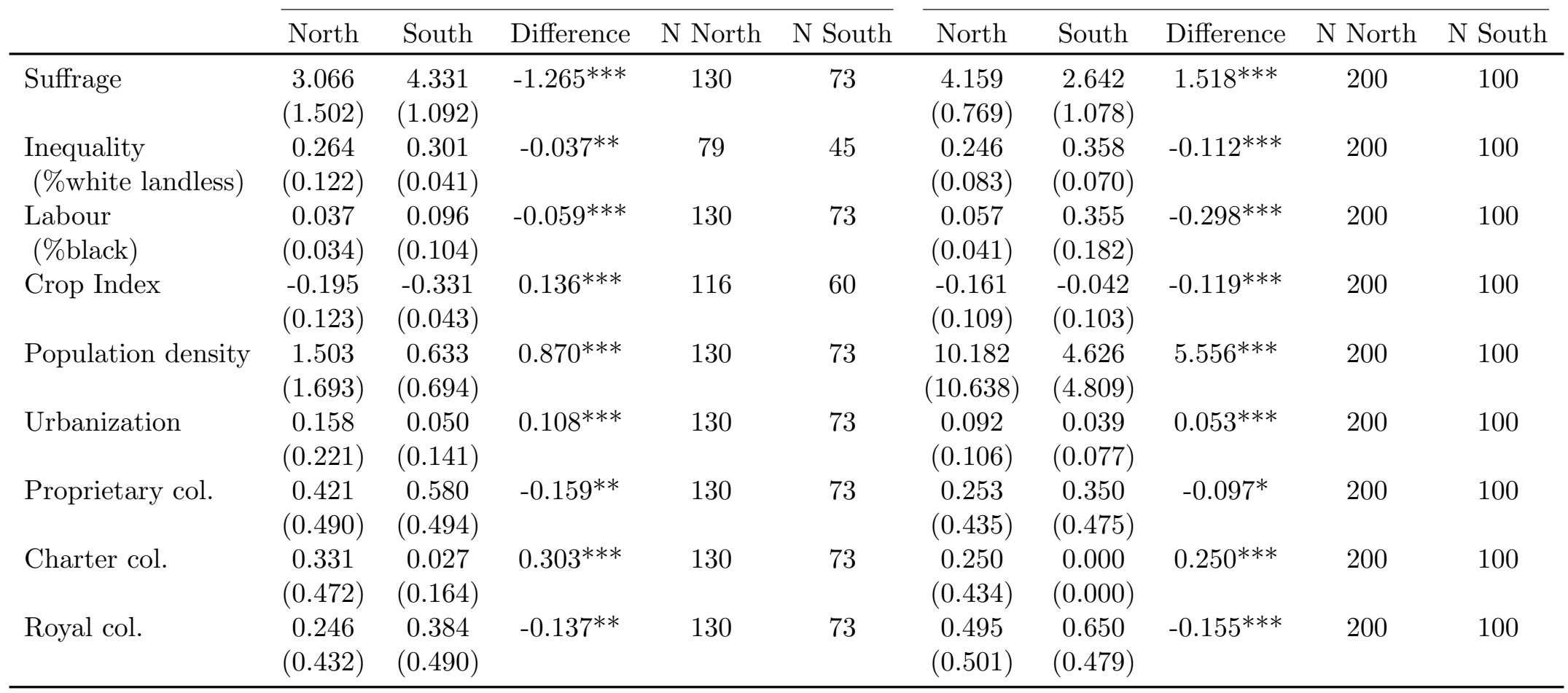

Sources: See text. Notes: This table shows means and standard variations of relevant variables by time period and region. The panel is obtained by taking three-year averages. The "Difference"-columns give the difference in means between North and South for the respective period and the significance based on a simple t-test. Standard errors are in parentheses. ${ }^{* * *} p \leq$ $0.01,{ }^{* *} p \leq 0.05,{ }^{*} p \leq 0.1$. 
Table A2: Estimated share of blacks in the South, 1610-1780

\begin{tabular}{cccccc}
\hline Year & Virginia & Maryland & North Carolina & South Carolina & Georgia \\
\hline 1610 & $0.00 \%$ & & & & \\
1620 & $0.91 \%$ & & & & \\
1630 & $2.00 \%$ & & & & \\
1640 & $1.44 \%$ & $3.43 \%$ & & & \\
1650 & $2.16 \%$ & $6.66 \%$ & & & \\
1660 & $3.52 \%$ & $9.00 \%$ & $2.00 \%$ & $15.00 \%$ & \\
1670 & $5.66 \%$ & $9.00 \%$ & $3.90 \%$ & $38.67 \%$ & \\
1680 & $6.88 \%$ & $9.00 \%$ & $3.87 \%$ & $37.46 \%$ & \\
1690 & $17.62 \%$ & $9.00 \%$ & $3.95 \%$ & $52 \%$ & \\
1700 & $27.99 \%$ & $10.90 \%$ & $3.87 \%$ & $64.54 \%$ & \\
1710 & $25.97 \%$ & $18.59 \%$ & $5.95 \%$ & $66.67 \%$ & \\
1720 & $30.26 \%$ & $18.90 \%$ & $14.10 \%$ & $72.32 \%$ & $0.00 \%$ \\
1730 & $30.35 \%$ & $18.90 \%$ & $20.00 \%$ & $66.22 \%$ & $19.23 \%$ \\
1740 & $33.25 \%$ & $20.70 \%$ & $21.25 \%$ & $60.95 \%$ & $37.36 \%$ \\
1750 & $45.25 \%$ & $30.80 \%$ & $27.13 \%$ & $60.51 \%$ & $45.45 \%$ \\
1760 & $41.38 \%$ & $30.20 \%$ & $30.38 \%$ & $53.89 \%$ & $37.15 \%$ \\
1770 & $41.97 \%$ & $31.50 \%$ & $35.29 \%$ & & \\
1780 & $41.00 \%$ & $33.47 \%$ & $33.69 \%$ & & \\
\hline
\end{tabular}

Source: Historical Statistics of the US Millennial Edition Online (2006), Table Eg1-59. Notes: This table shows the growth of the black population in the South. Slavery was forbidden in Georgia until 1749. 
Figure A1: Colonial British America in 1763

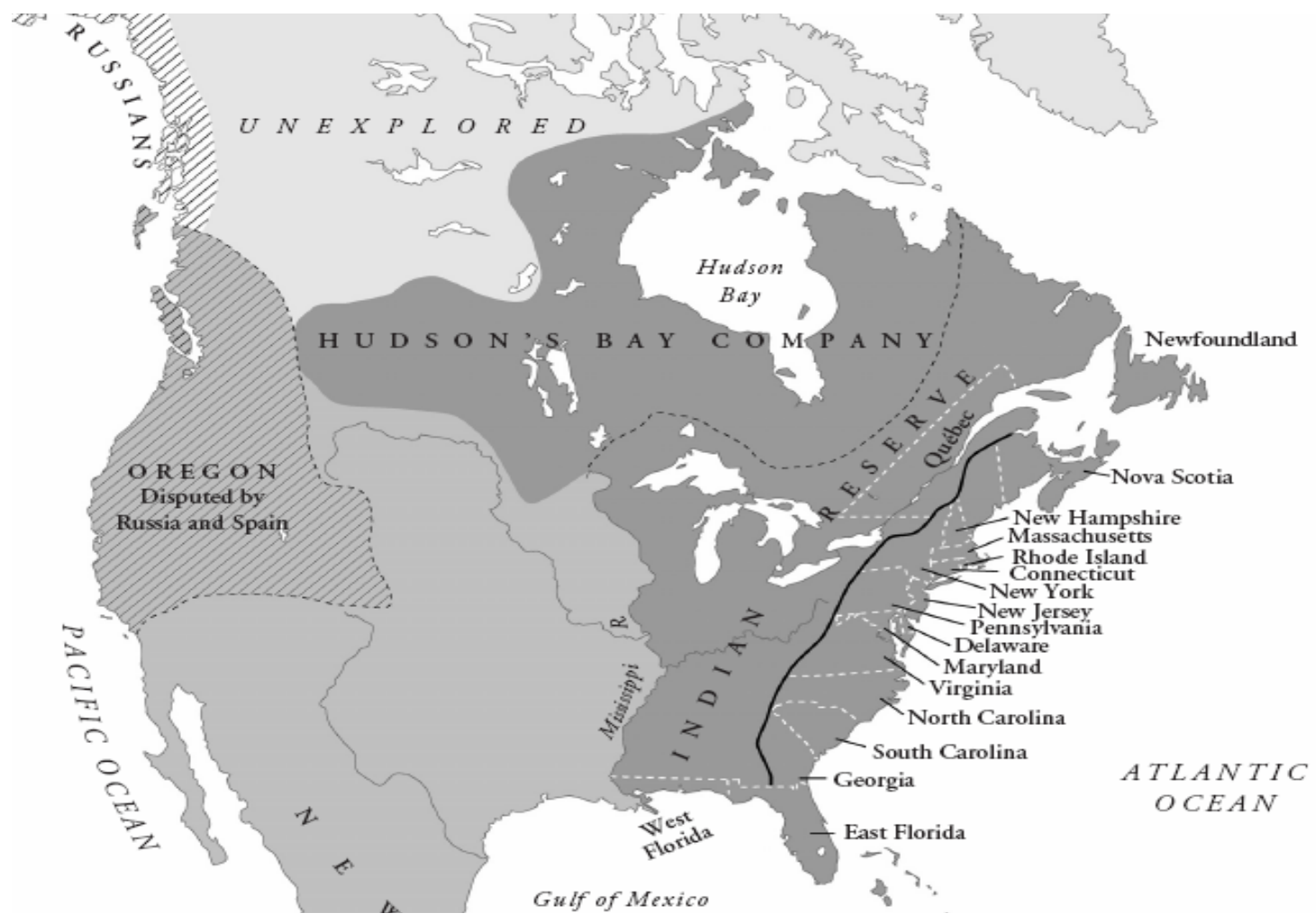


Figure A2: Correlation between the suffrage index (including restrictions for race) and suffrage extensiveness

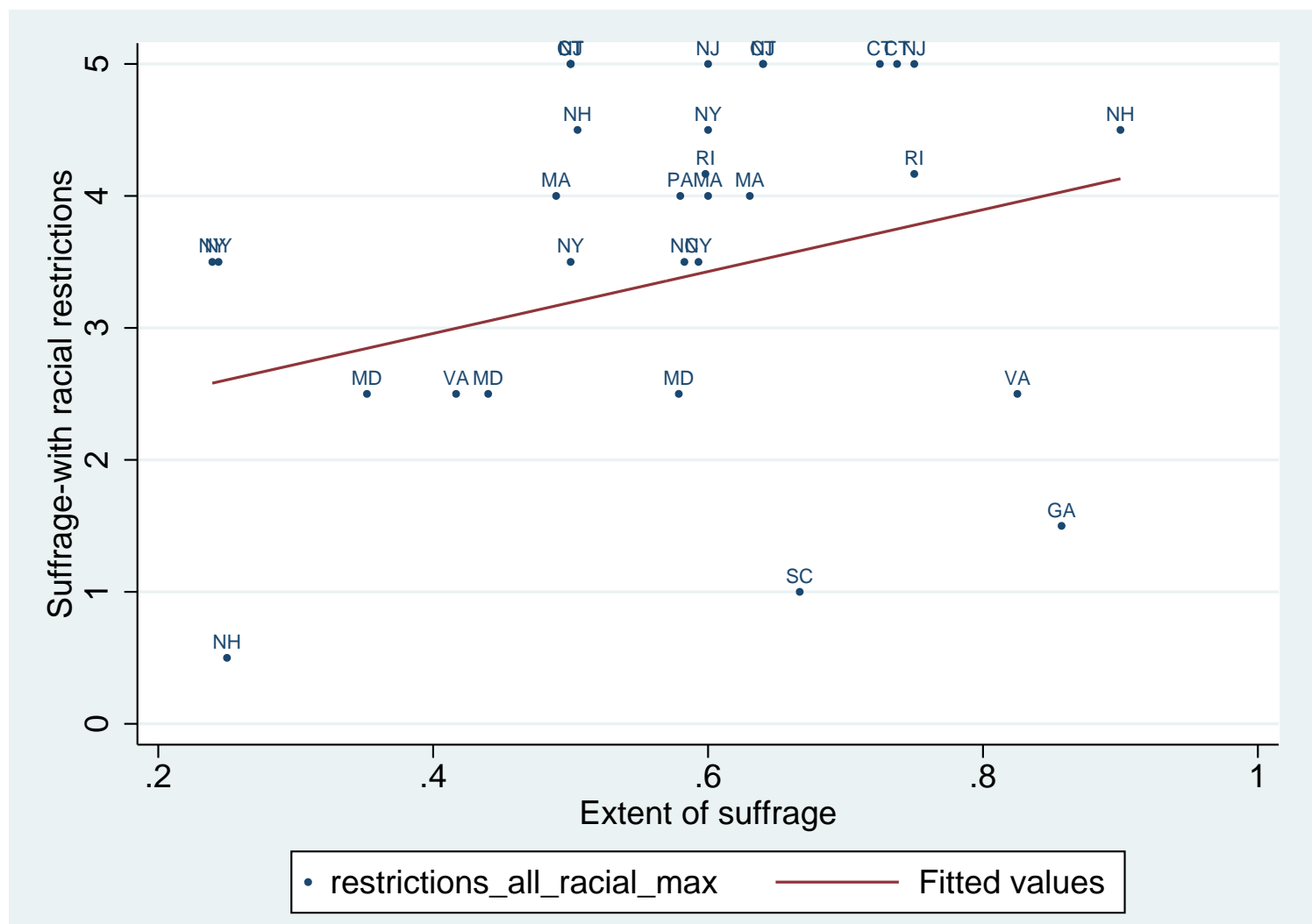

Sources: McKinley (1905) and Dinkin (1977). Notes: This figure presents the correlation between suffrage (including restrictions for race) and fragmentary suffrage extensiveness numbers for the period 1730-1775. A higher value of suffrage implies a more liberal political system. 
Figure A3: Correlation between the suffrage index (excluding restrictions for race) and suffrage extensiveness

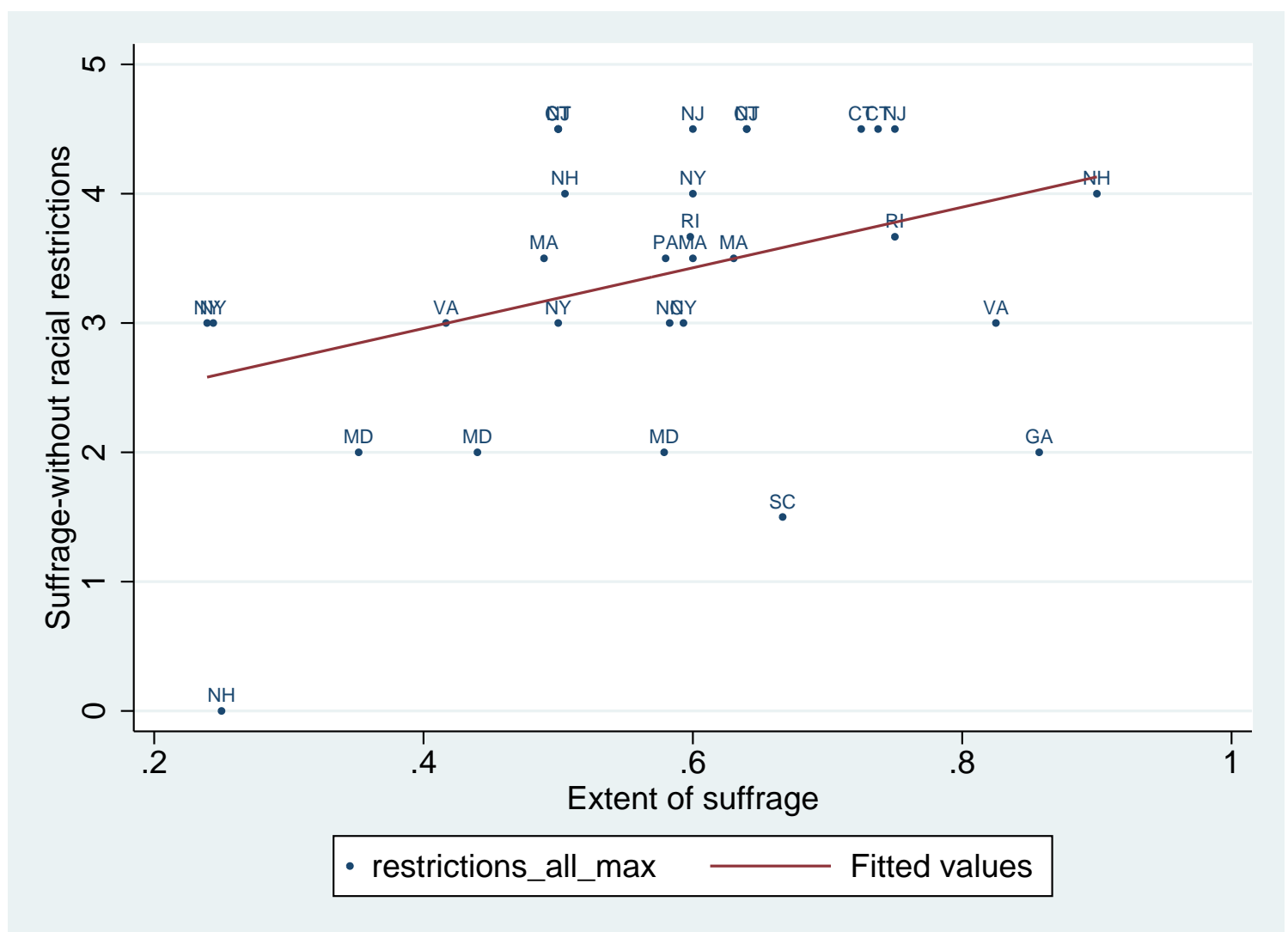

Sources: McKinley (1905) and Dinkin (1977). Notes: This figure presents the correlation between suffrage (excluding restrictions for race) and fragmentary suffrage extensiveness numbers for the period 1730-1775. A higher value of suffrage implies a more liberal political system. 
Figure A4: Sex ratio and the suffrage

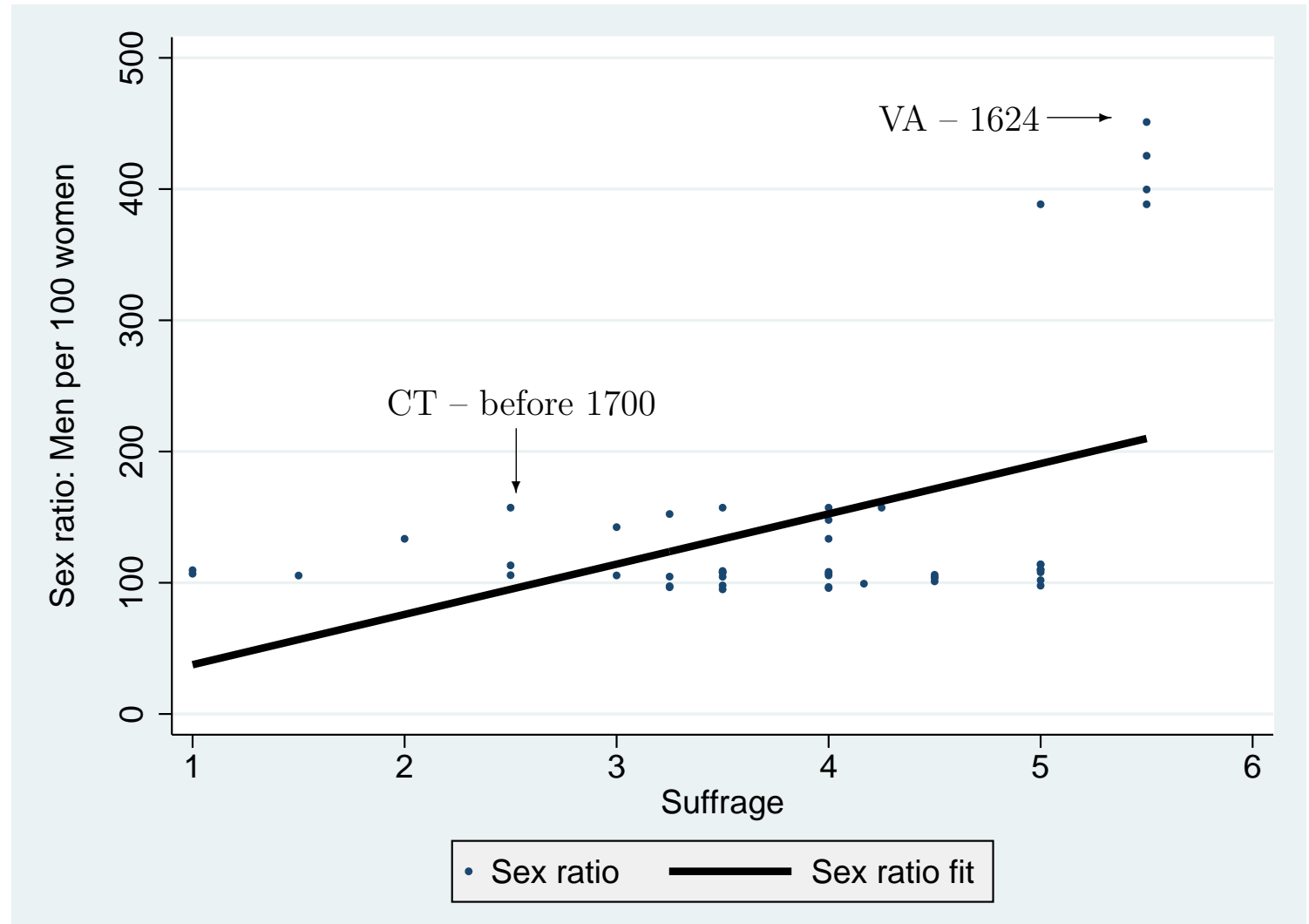

Sources: Wells (1975) and Moller (1945). Notes: This graph shows the relationship between suffrage and the sex ratio for selected Northern and Southern colonies over time. The sex ratio is calculated as the number of men per 100 women. The solid line is obtained by locally weighted least squares smoothing over all observations. 
Figure A5: Life expectancy and the suffrage - South

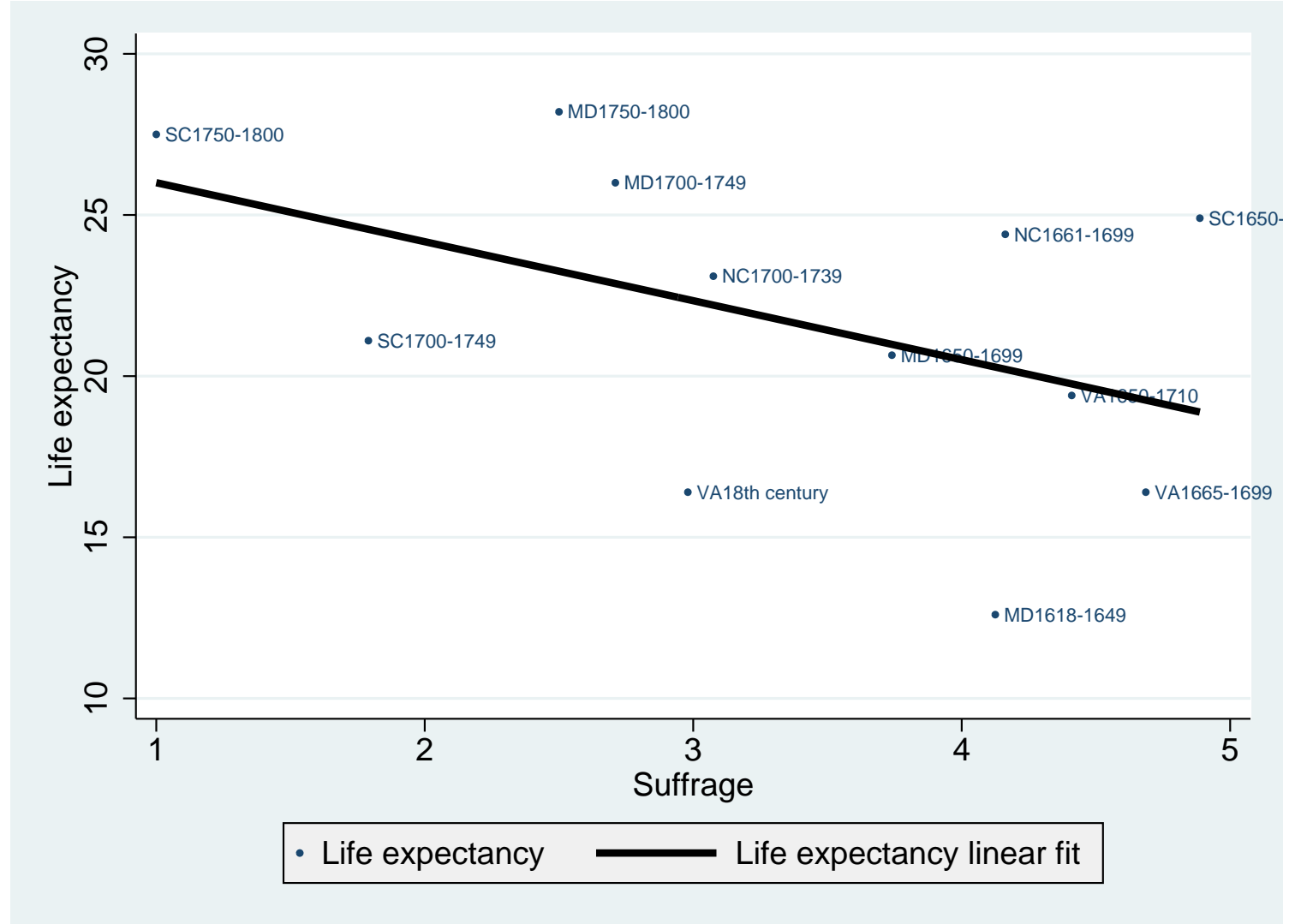

Sources: Galenson (1996) and Purvis (1999). Notes: This graph shows the relationship between suffrage and life expectancy for selected Southern colonies. Life expectancy is male life expectancy at age 30 . The solid line is obtained by a linear fit. 
Figure A6: Suffrage and labour markets within the North (Middle colonies)

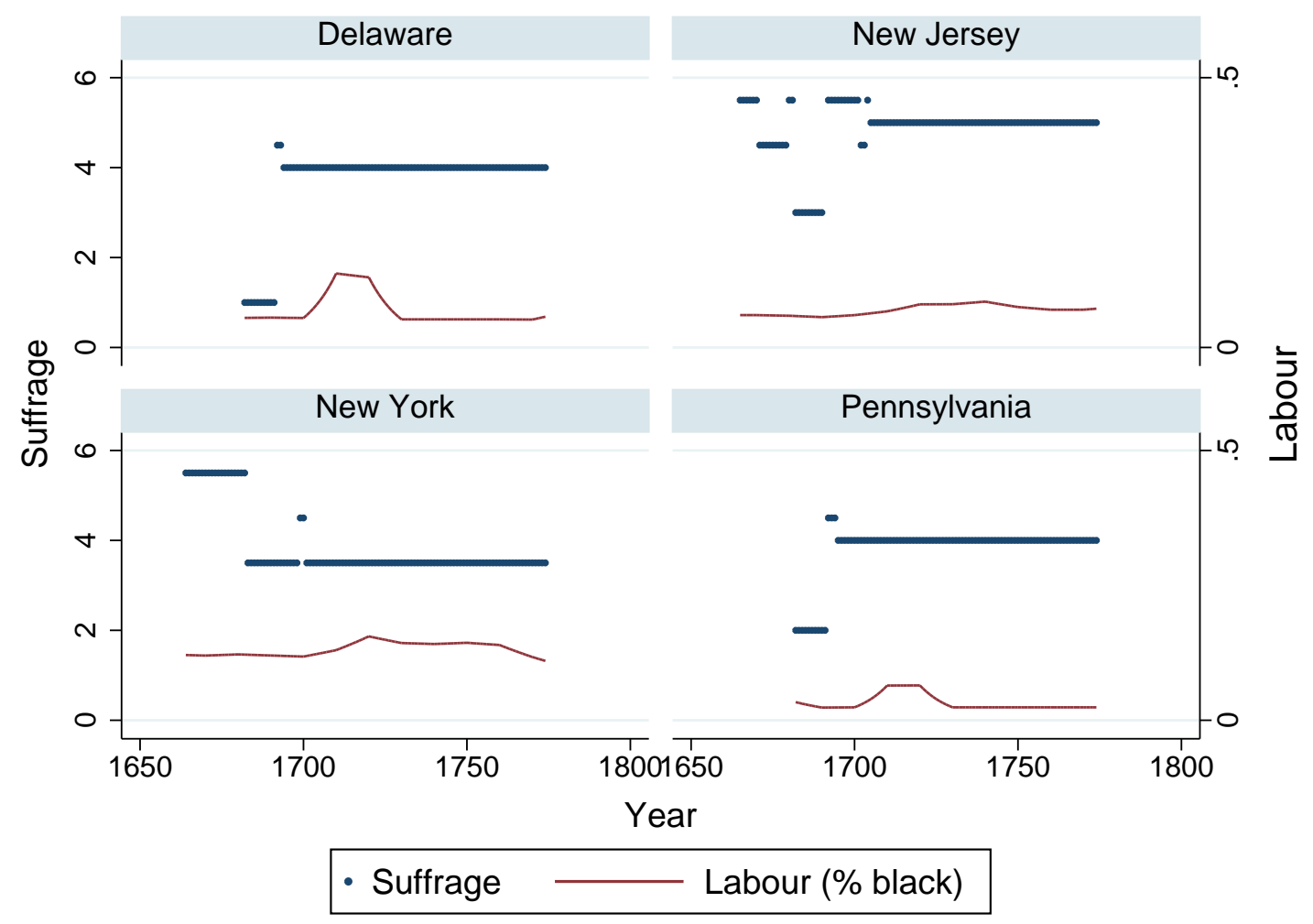

Sources: see text. Notes: This graph shows how suffrage and labour markets evolved over time for each of the Middle colonies. 
Figure A7: Suffrage and inequality within the North (Middle colonies)

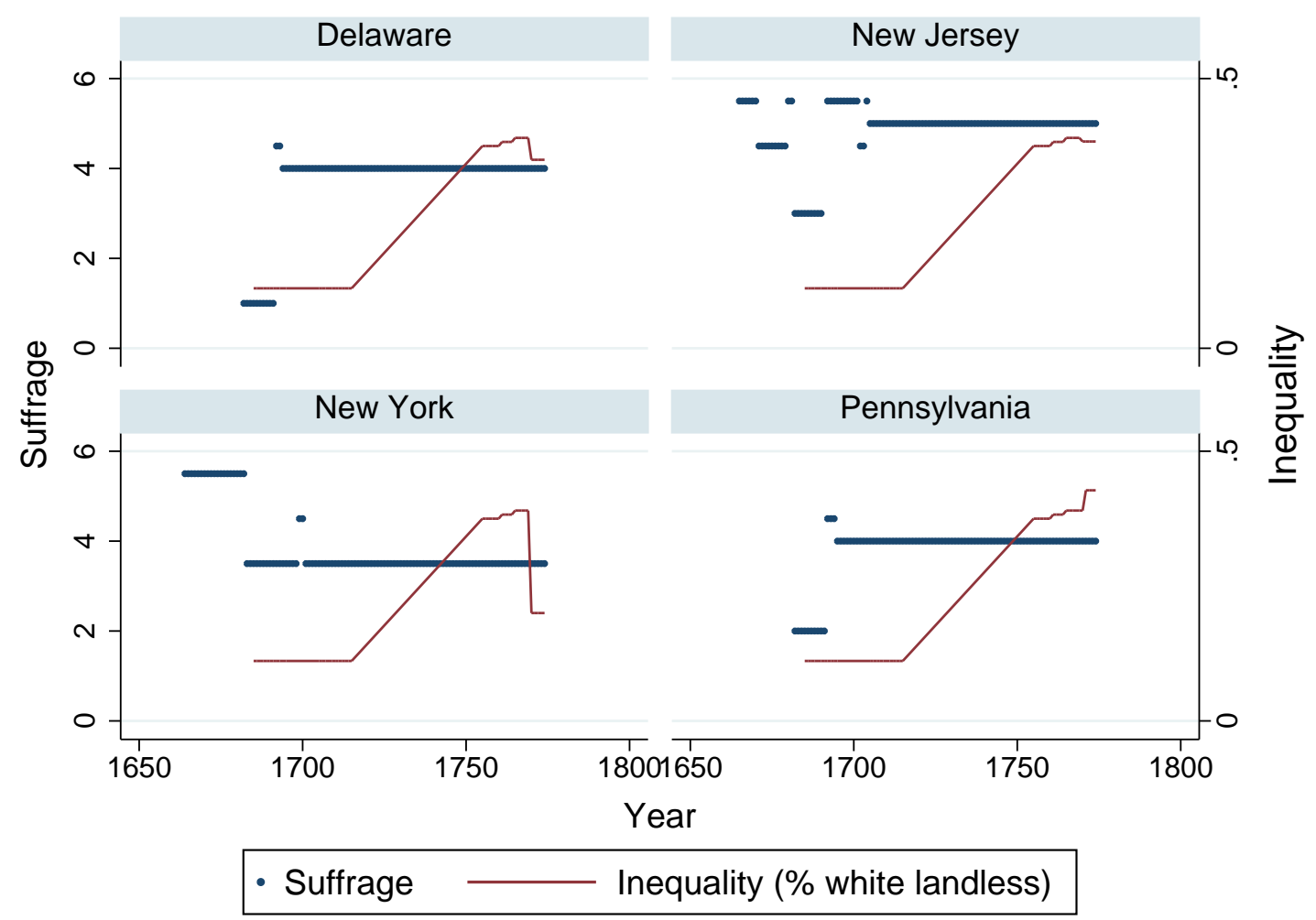

Sources: see text. Notes: This graph shows how suffrage and inequality evolved over time for each of the Middle colonies. 
Figure A8: Suffrage and labour markets within the North (New England colonies)

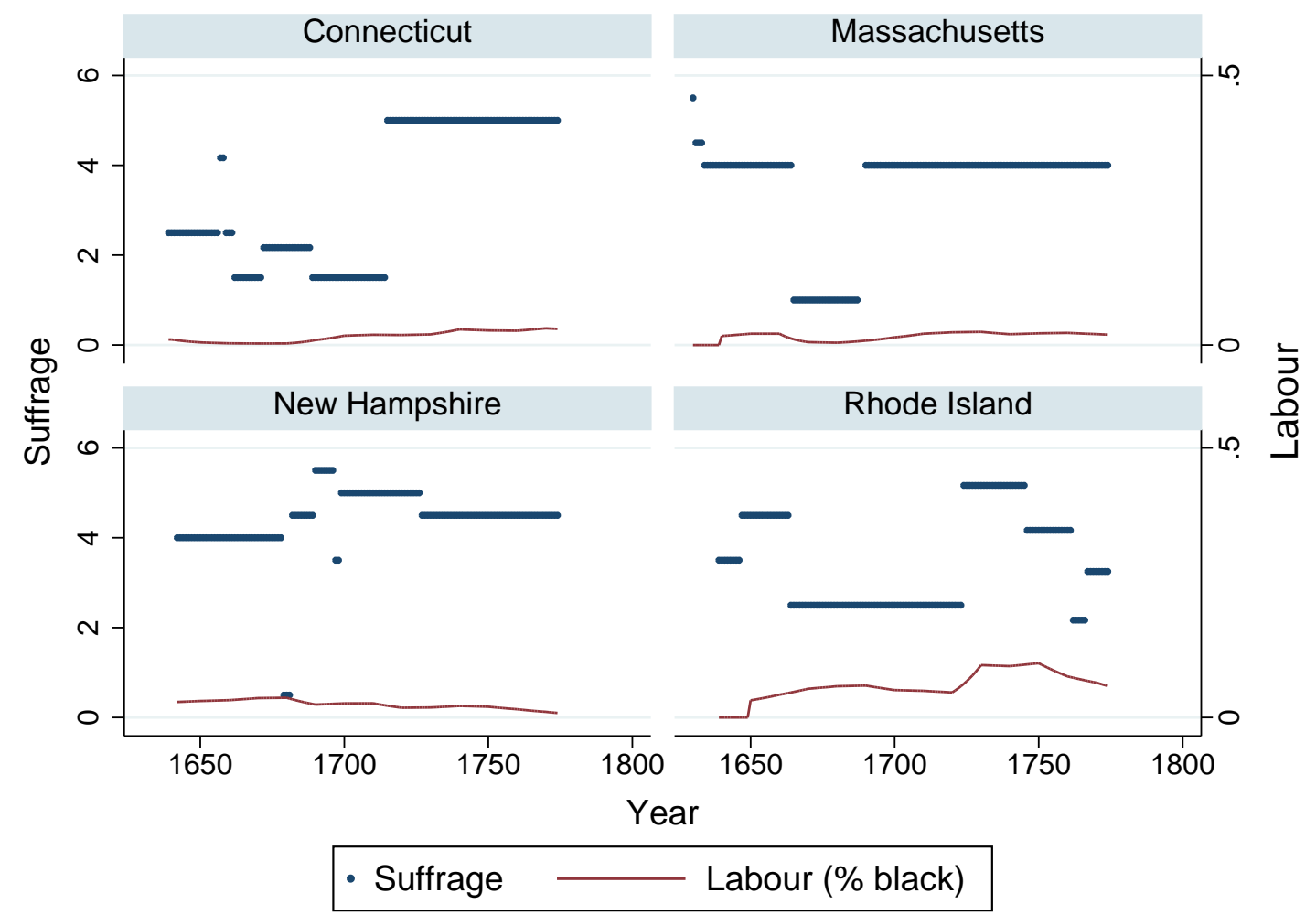

Sources: see text. Notes: This graph shows how suffrage and labour markets evolved over time for each of the New England colonies. 
Figure A9: Suffrage and inequality within the North (New England colonies)

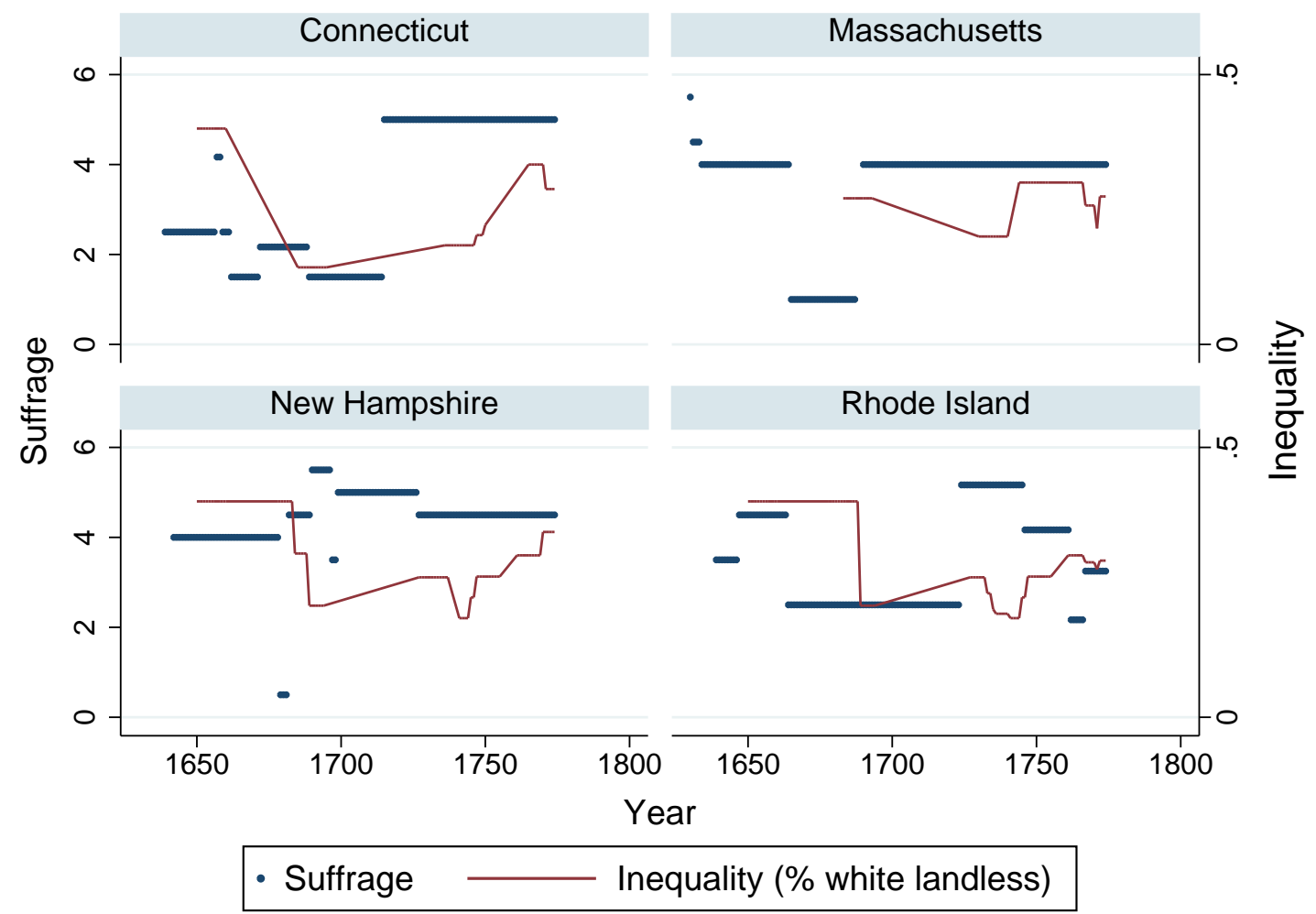

Sources: see text. Notes: This graph shows how suffrage and inequality evolved over time for each of the New England colonies. 
Figure A10: Evolution of the crop index instrument, by colony

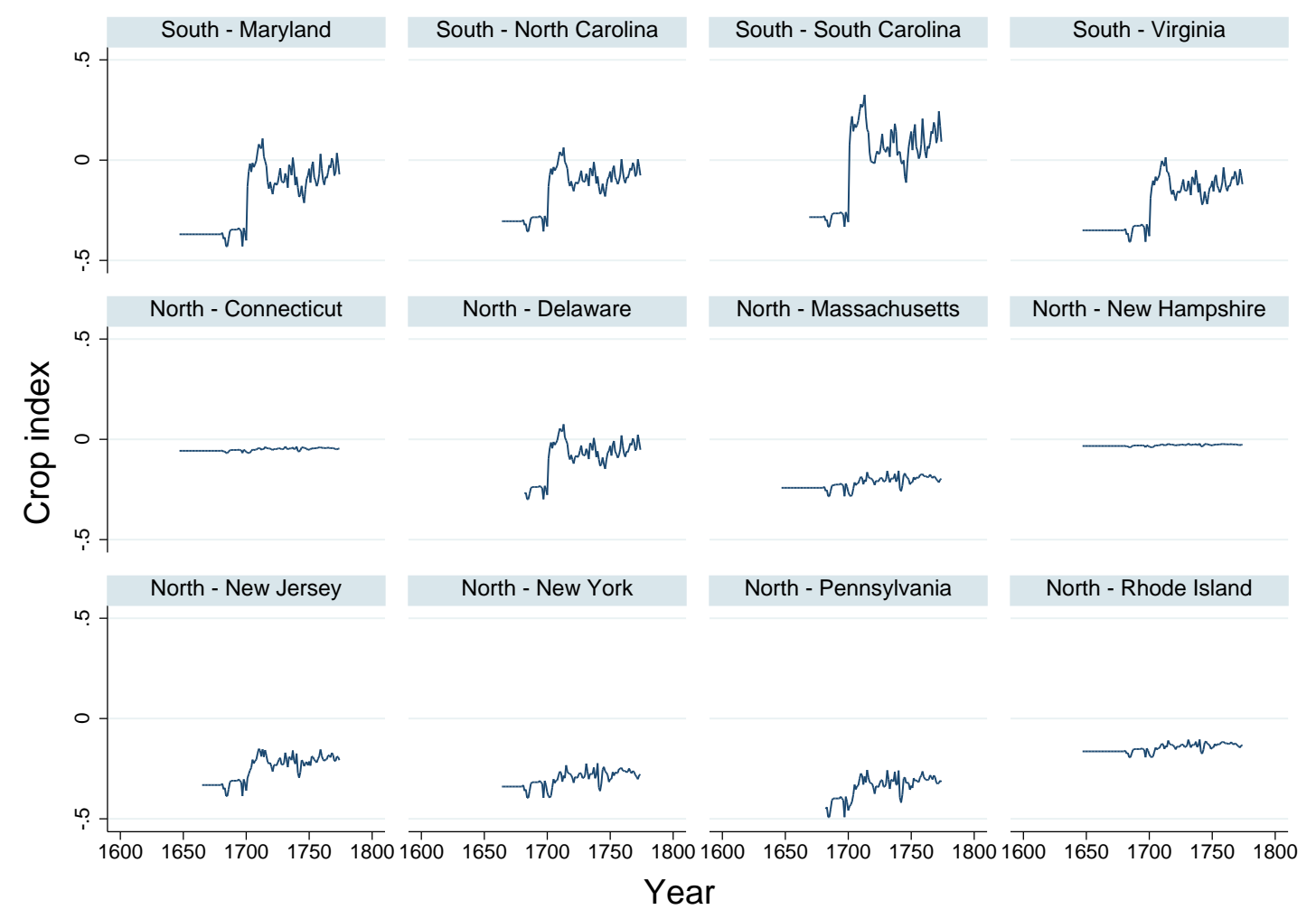

Sources: see text. Notes: This graph shows the evolution of the crop index instrument over time for each of the British American colonies. See the text for more information on how the instrument is calculated. 
Figure A11: Price series for tobacco, rice and wheat (English pence per pound) (a) Tobacco - Virginia

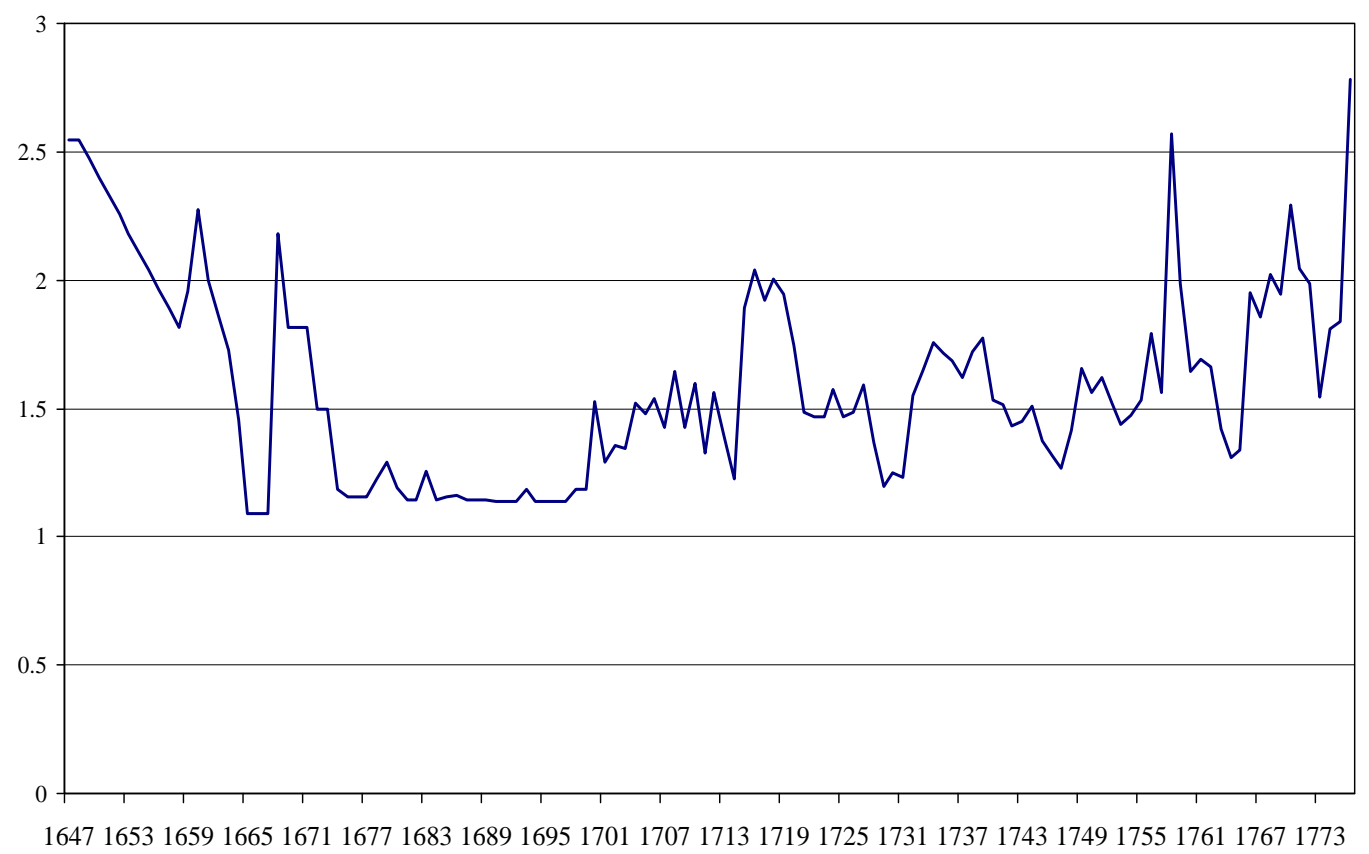

(b) Rice - Charleston, South Carolina

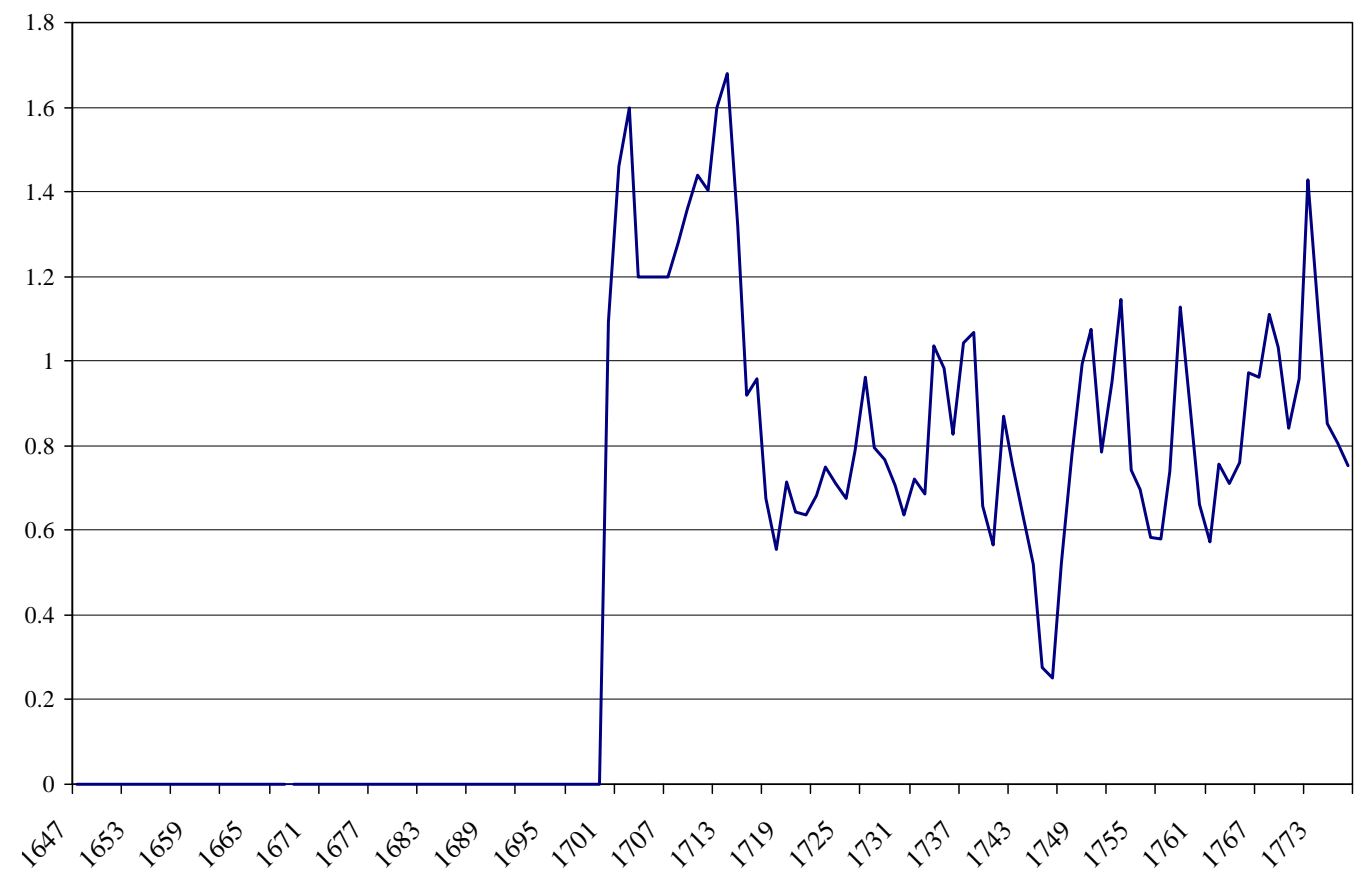


(c) Wheat - Talbot County, Maryland

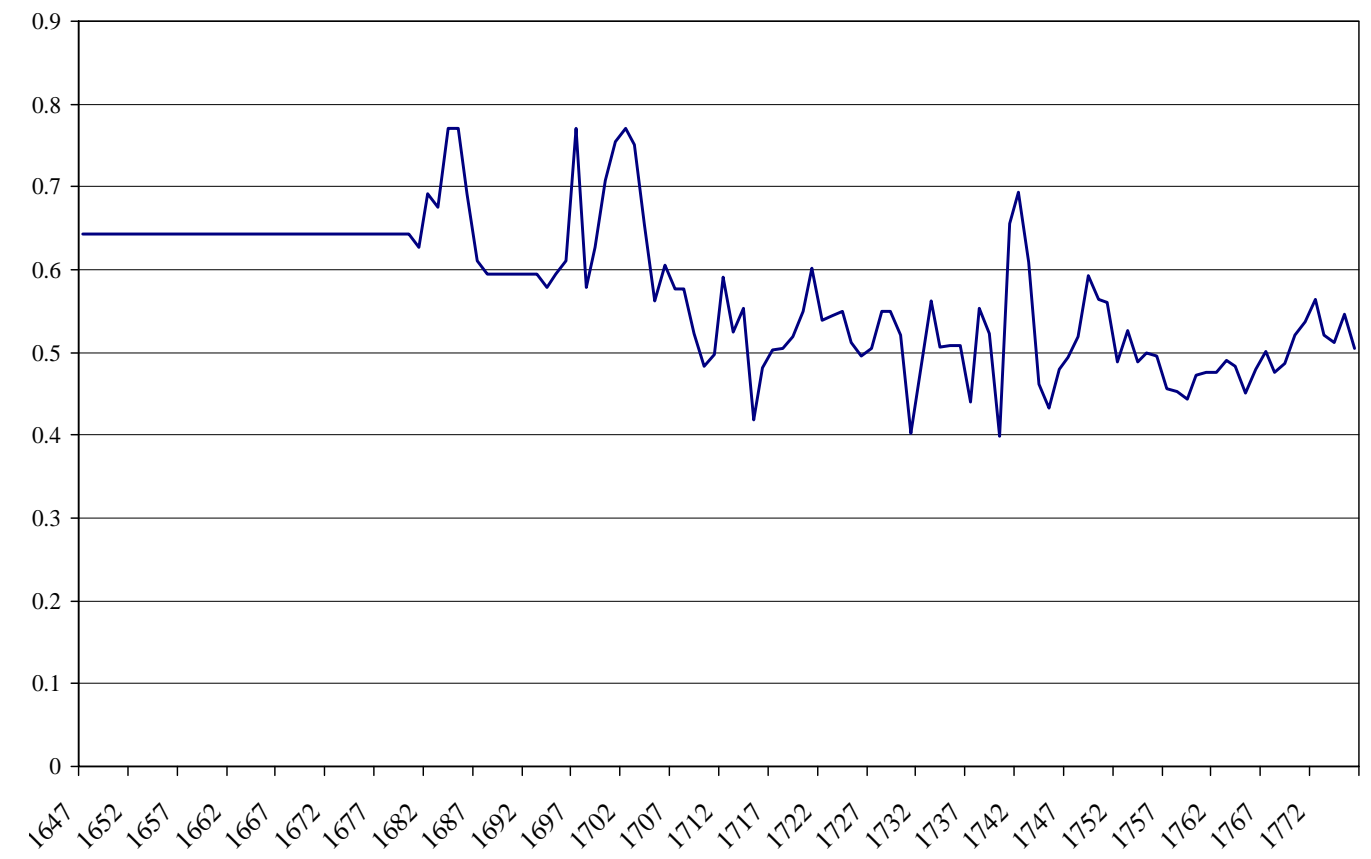

Sources: Historical Statistics of the US Millennial Edition Online (2006) and Purvis (1999). Notes: These graphs show the price movements for the three main export crops of colonial British America. 
Figure A11: Inequality and labour markets by colony, South
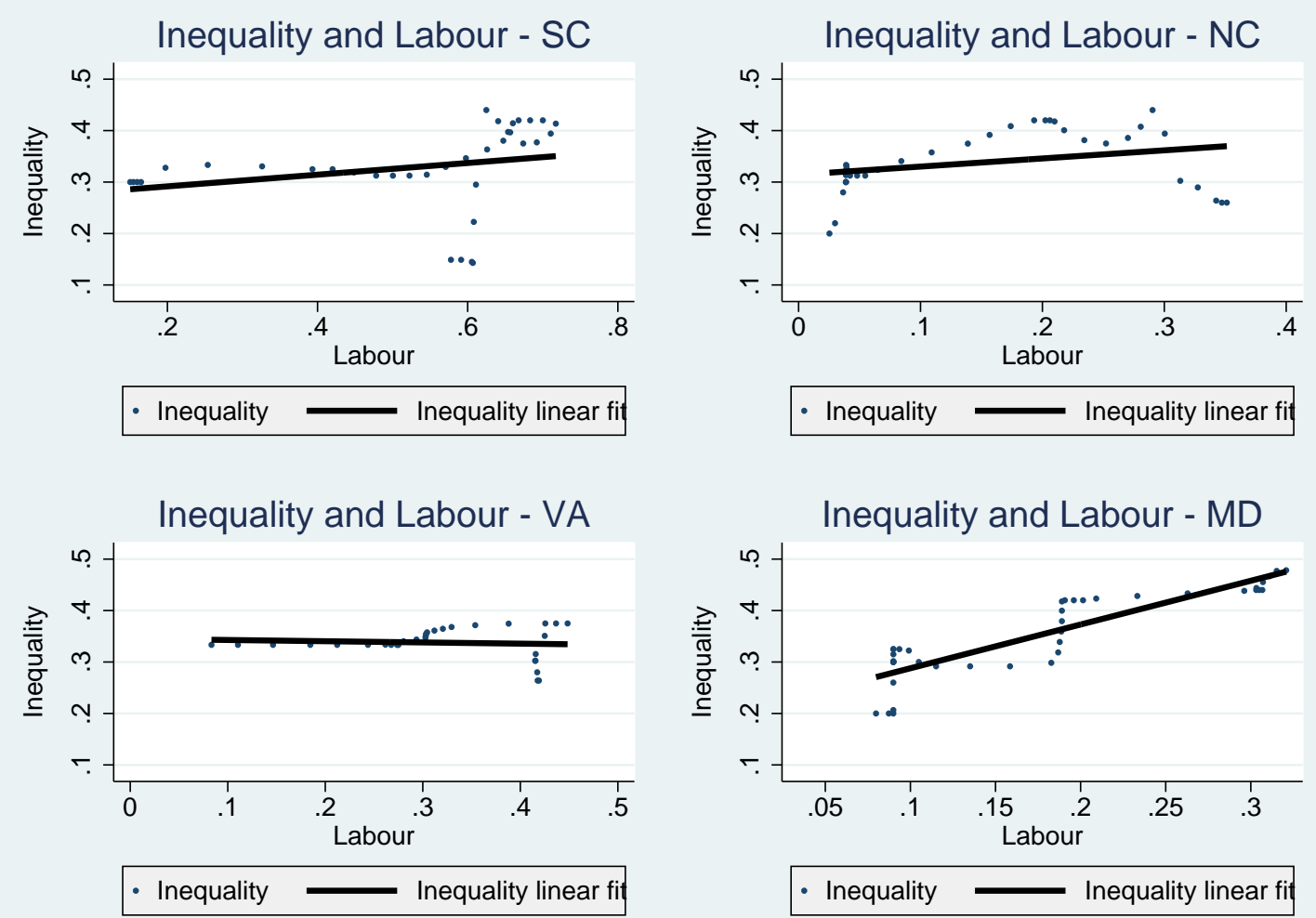

Sources: see text. Notes: This graph shows the unconditional correlation between inequality (percent white landless) and labour markets (percent black) in North Carolina, South Carolina, Virginia and Maryland. The data set is obtained by taking every third observation for each colony. Each dot represents an observation for a particular colony and year. The solid line is obtained through a linear fit. 
Figure A12: Inequality and labour markets - South

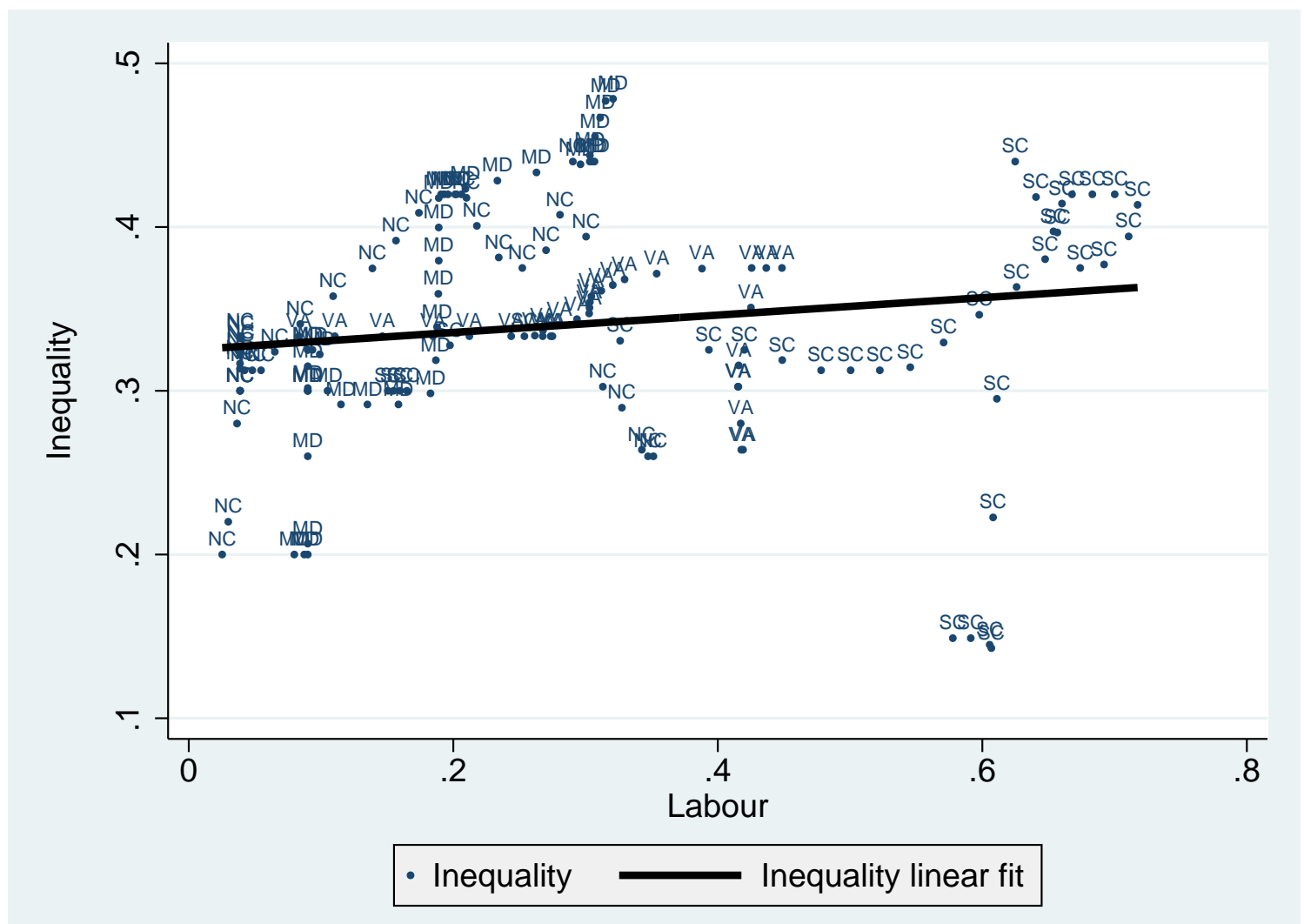

Sources: see text. Notes: This graph shows the unconditional correlation between inequality (percent white landless) and labour markets (percent black) in the South. The data set is obtained by taking every third observation for each colony. Each dot represents an observation for a particular colony and year. The solid line is obtained through a linear fit. 
Figure A13: Inequality and labour markets - North and South

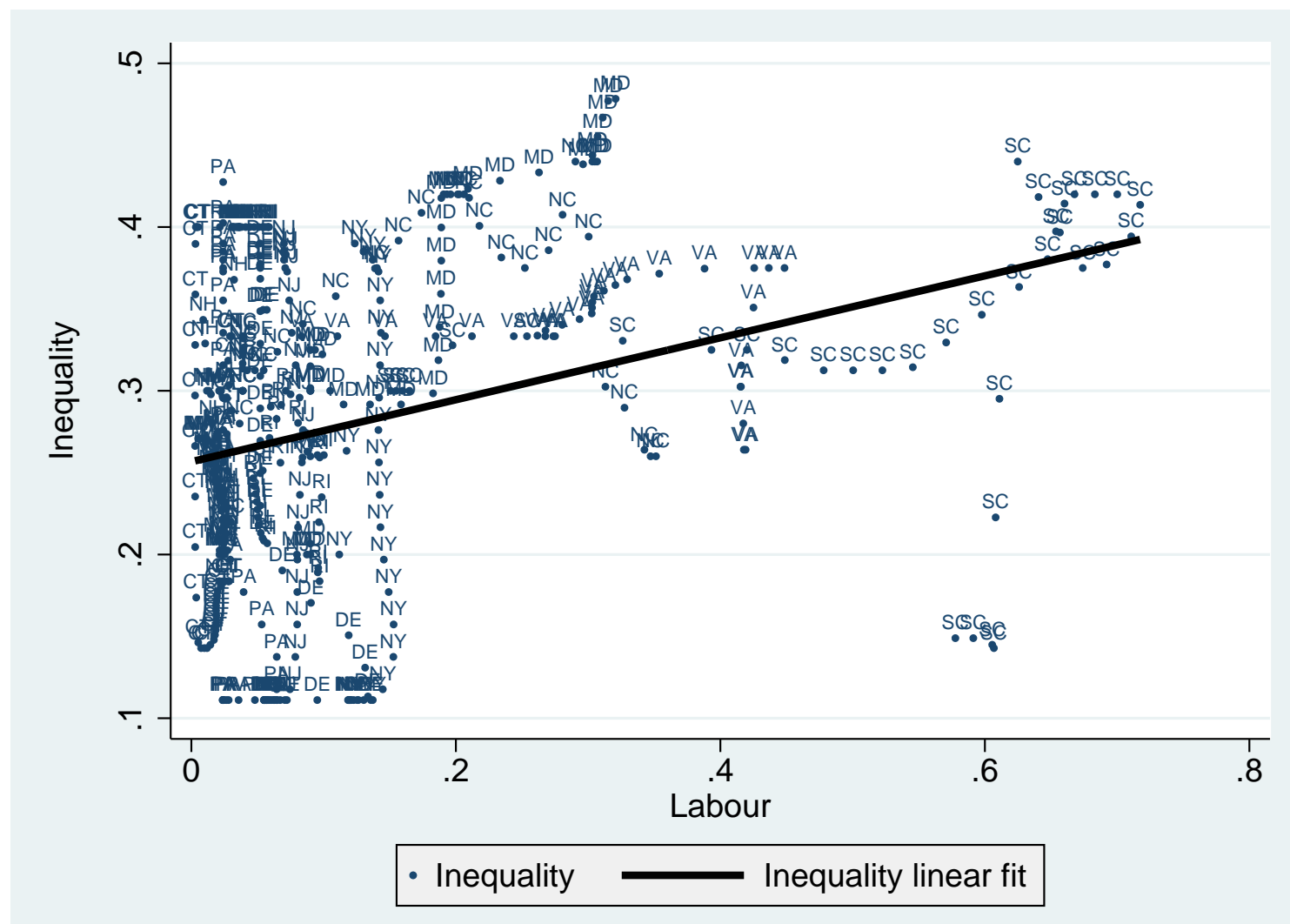

Sources: see text. Notes: This graph shows the unconditional correlation between inequality (percent white landless) and labour markets (percent black) in the entire sample. The data set is obtained by taking every third observation for each colony. Each dot represents an observation for a particular colony and year. The solid line is obtained through a linear fit. 


\section{Part 2: Additional threats to validity and robustness checks}

\section{The importance of the Scotch-Irish}

There are several reasons why the tightening of the Southern franchise in the early eighteenth century is unlikely to have been prompted by the Scotch-Irish migration wave of 1717-1775. First, the Scotch-Irish were never a majority of the population: even in South Carolina, the colony with the greatest share of Scotch-Irish settlers, they were only $18.9 \%$ of the total population in 1790. Second, as Figures 1 and 2 show, the tightening of the Southern franchise took place before 1717. Moreover, a great number of Scotch-Irish settlers also arrived in Pennsylvania, Delaware and New York, yet the franchise in these colonies followed a very different pattern compared to that in the South.

Even so, I test to what extent my results are influenced by Scotch-Irish migration patterns in Table A5. In column 5, I include a variable which interacts a dummy for the period 1717-1775 with dummies for those colonies in which the share of the Scotch-Irish population was above 10\% in 1790 (PA, MD, VA, NC and SC). In column 6, I instead consider colonies where the percentage of the Scotch-Irish was above $8 \%$ (all of the previous colonies, as well as DE, ME and NY). In both cases, the coefficient on labour is negative, significant and similar in magnitude as compared to the estimates in the baseline specification.

\section{Racially motivated conflicts}

A final scenario is that elites opted to tighten the suffrage in colonies with large black populations not because they no longer needed to attract white labourers, but in order to pre-empt conflicts along racial lines. First, it is possible that colonies that depended on slavery also had diverse white populations, which found it harder to agree on the design of political regimes and therefore ended up with more author- 
itarian institutions (Alesina et al., 1999). I deal with this possibility by including controls for the ethnic and religious fractionalisation of the white population in 1790 in Table A5. I collect colony-level data on the ancestral origins of the white population in 1790 and on the distribution of different types of churches in 1750, from which I calculate Herfindahl-Hirschman Index-type indices of ethnic fractionalisation and religious fractionalisation and include those in the regressions (columns 1-4). Because these variables are fixed over time, I am unable to include colony fixed effects and instead only control for latitude in the regressions. If the colonies were highly divided on these dimensions, it could have been more difficult for actors to coordinate on the democratic outcome, and more autocratic institutions would have emerged (Alesina et al. 1999 and Easterly and Levine 1997). ${ }^{27}$ The coefficients on ethnic fractionalisation and religious fractionalisation are mostly insignificant and unstable across regression aggregations, without affecting the significance and magnitude of the coefficients on the rest of the variables.

Alternatively, it is also possible that Southern elites adopted a less democratic political system after the arrival of slavery due to fears that new white settlers may try to abolish the institution of slavery. However, with the exception of a few Quaker activists who had limited success in persuading other Quakers to stop using slaves, abolitionist sentiments were rare during colonial times, and slaveholders dominated political life both before and after 1775 . Last, there is little evidence that Southern elites tightened the suffrage after the arrival of slavery in order to to prevent joint white-black rebellions. In fact, the colonies experienced few insurrections in the eighteenth century, and most of them involved blacks rebelling against whites (Harrold, 2001; Olasiji, 1995).

\footnotetext{
${ }^{27}$ The correlation between these two measures is 0.87 .
} 


\section{Additional robustness checks}

In Table A3, I experiment with alternative definitions of the dependent variable. First, suffrage is non-negative and censored above by 6.5, so I present a Tobit regression in column (1). In columns 2-3, I run regressions with an annual panel which also includes all observations. In the last two columns, I run a specification which only keeps those restrictions on the suffrage that were identified as important by Dinkin (1977). ${ }^{28}$ The coefficients in these specification are in line with those in Table 1, while the impact of inequality is slightly weaker.

In Table A4, I present additional aggregations of the suffrage index. I try different weighting schemes in columns (1-4): no accounting for substitutability among restrictions (columns 1-2) as well as an alternative substitutability weighting (columns 3-4). I also calculate the suffrage index using principal component analysis on each suffrage restriction (columns 5-6). Last, in columns (7)-(8), I present a specification where suffrage is recoded as 1 if there are restrictions related to any of the following categories: income, freeholding, the existence of minimum freeholding or property, tax, residency or religion; and is 0 otherwise. The OLS and 2SLS coefficients on labour in columns (7) and (8) are much smaller in magnitude - likely because all of these restrictions matter in determining the quality of colonial representative institutions.

In Table A6, I show that the baseline results are robust to dropping the colony fixed effects (columns 1-2), the lagged dependent variable (columns 3-4), both (columns 5-6), and to using a ten-year average panel (column 7). Not surprisingly, results are much stronger when the lagged dependent variable is excluded. In Tables A7 and A8, I show that the results change little when (1) inequality is dropped from the regressions and (2) when different independent variables are excluded from the 2SLS specifications.

\footnotetext{
${ }^{28}$ Suffrage Dinkin drops the restrictions for: freemanship, formal patenting of lands, householding, and being a good person.
} 
Table A3: Suffrage in the 13 colonies: Robustness checks 2

\begin{tabular}{|c|c|c|c|c|c|}
\hline & $\begin{array}{c}(1) \\
\text { Tobit }\end{array}$ & $\begin{array}{c}(2) \\
\text { OLS } \\
\text { All obs \& } \\
\text { years }\end{array}$ & $\begin{array}{c}(3) \\
\text { 2SLS } \\
\text { All obs \& } \\
\text { year }\end{array}$ & $\begin{array}{c}(4) \\
\text { OLS } \\
\text { Suffrage } \\
\text { Dinkin }\end{array}$ & $\begin{array}{c}(5) \\
\text { 2SLS } \\
\text { Suffrage } \\
\text { Dinkin }\end{array}$ \\
\hline Lagged Suffrage & $\begin{array}{c}0.806^{* * *} \\
(0.0407)\end{array}$ & $\begin{array}{c}0.870^{* * *} \\
(0.0330)\end{array}$ & $\begin{array}{c}0.866^{* * *} \\
(0.0378)\end{array}$ & $\begin{array}{c}0.790^{* * *} \\
(0.0440)\end{array}$ & $\begin{array}{c}0.775^{* * *} \\
(0.0626)\end{array}$ \\
\hline Labour (\%black) & $\begin{array}{c}-1.977^{* * *} \\
(0.578)\end{array}$ & $\begin{array}{c}-\mathbf{1 . 1 4 1}^{\text {****}} \\
(0.321)\end{array}$ & $\begin{array}{c}-\mathbf{1 . 3 1 8}^{*} \\
(0.688)\end{array}$ & $\begin{array}{c}-\mathbf{1 . 6 1 5}^{\text {****}} \\
(0.445)\end{array}$ & $\begin{array}{r}-\mathbf{2 . 0 5 6} \\
(1.337)\end{array}$ \\
\hline Inequality (\%white 1.less) & $\begin{array}{c}-0.681^{* *} \\
(0.322)\end{array}$ & $\begin{array}{c}-0.255 \\
(0.173)\end{array}$ & $\begin{array}{c}-0.257 \\
(0.175)\end{array}$ & $\begin{array}{r}-0.464^{*} \\
(0.244)\end{array}$ & $\begin{array}{r}-0.465^{*} \\
(0.239)\end{array}$ \\
\hline Urbanisation & $\begin{array}{c}0.207 \\
(0.273)\end{array}$ & $\begin{array}{c}0.136 \\
(0.0982)\end{array}$ & $\begin{array}{c}0.132 \\
(0.0976)\end{array}$ & $\begin{array}{c}0.190 \\
(0.202)\end{array}$ & $\begin{array}{c}0.185 \\
(0.192)\end{array}$ \\
\hline Population density & $\begin{array}{c}0.00712 \\
(0.00617)\end{array}$ & $\begin{array}{c}0.00431 \\
(0.00317)\end{array}$ & $\begin{array}{c}0.00392 \\
(0.00320)\end{array}$ & $\begin{array}{c}0.00412 \\
(0.00527)\end{array}$ & $\begin{array}{c}0.00355 \\
(0.00530)\end{array}$ \\
\hline Year control & $\checkmark$ & $\checkmark$ & $\checkmark$ & $\checkmark$ & $\checkmark$ \\
\hline Colony fixed effects & $\checkmark$ & $\checkmark$ & $\checkmark$ & $\checkmark$ & $\checkmark$ \\
\hline Additional controls & $\checkmark$ & $\checkmark$ & $\checkmark$ & $\checkmark$ & $\checkmark$ \\
\hline $\begin{array}{l}\text { Observations } \\
\text { Mean suffrage } \\
R^{2}\end{array}$ & $\begin{array}{r}412 \\
3.633 \\
0.868\end{array}$ & $\begin{array}{r}1316 \\
3.543 \\
0.885\end{array}$ & $\begin{array}{r}1316 \\
3.543 \\
0.885\end{array}$ & $\begin{array}{l}412 \\
3.491 \\
0.841\end{array}$ & $\begin{array}{r}412 \\
3.491 \\
0.841\end{array}$ \\
\hline $\begin{array}{l}\text { First-Stage Results } \\
\text { Instrument Coefficient } \\
1^{s t} \text { stage } R^{2}\end{array}$ & & & $\begin{array}{c}0.299 * * * \\
(0.025) \\
0.918\end{array}$ & & $\begin{array}{c}0.280 * * * \\
(0.044) \\
0.928\end{array}$ \\
\hline
\end{tabular}

Sources: See text. Notes: This table shows results from OLS, 2SLS and Tobit regressions explaining the suffrage in the 13 British American colonies (robustness checks). All independent variables are lagged by one period (three years for columns 1; 2-5; one year for columns 2-3). A linear trend is used as "Year control". Additional controls include a dummy for when each colony was proprietary or charter (with royal as omitted category). Robust standard errors are in parentheses. ${ }^{* * *} p \leq 0.01,{ }^{* *} p \leq 0.05,{ }^{*} p \leq 0.1$. 
Table A4: Suffrage in the 13 colonies: Robustness checks 3

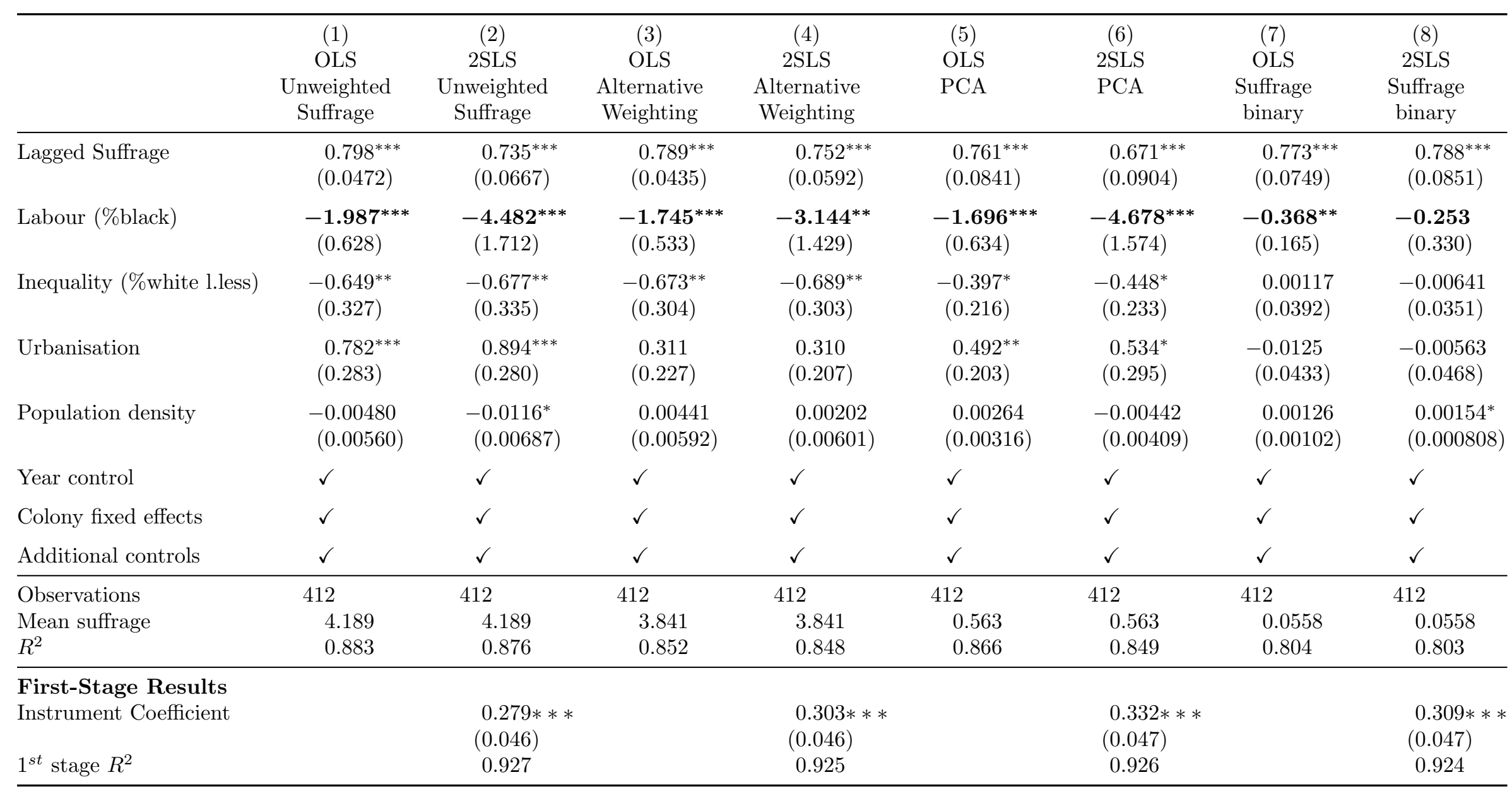

Sources: See text. Notes: This table shows results from OLS and 2SLS regressions explaining suffrage in the 13 British American colonies (robustness checks). All independent variables are lagged by one period (three years). A linear trend is used as "Year control". Additional controls include a dummy for when each colony was proprietary or charter (with royal as omitted category). "Unweighted suffrage" means that the index does not account for restrictions that can be substituted with one or more other restrictions. "Alternative weighting" gives a weight of $1 / 2$ to restrictions that can be substituted with one other restriction, and $1 / 3$ to restrictions that can be substituted with two other restrictions. Columns 5 - 6 calculate suffrage via principal component analysis. Columns 7-8 create a binary suffrage index which takes a value of 1 of any of the following restrictions are in place: income, freeholding, the existence of minimum freeholding or property, tax, residency or religion; and 0 otherwise. Robust standard errors are in parentheses. $* * * p \leq 0.01,{ }^{* *} p \leq 0.05,{ }^{*} p \leq 0.1$. 
Table A5: Suffrage in the 13 colonies: Robustness checks 4

\begin{tabular}{|c|c|c|c|c|c|c|}
\hline & $\begin{array}{c}(1) \\
\text { OLS } \\
\text { Ethnic fract. }\end{array}$ & $\begin{array}{c}\text { 2SLS } \\
\text { Ethnic fract. }\end{array}$ & $\begin{array}{c}(3) \\
\text { OLS } \\
\text { Rel. fract. }\end{array}$ & $\begin{array}{c}\quad(4) \\
\text { 2SLS } \\
\text { Rel. fract. S }\end{array}$ & $\begin{array}{c}(5) \\
\text { OLS } \\
\text { Scotch-Irish }\end{array}$ & $\begin{array}{c}(6) \\
\text { 2SLS } \\
\text { Scotch-Irish }\end{array}$ \\
\hline Lagged Suffrage & $\begin{array}{c}0.820^{* * *} \\
(0.0361)\end{array}$ & $\begin{array}{c}0.821^{* * * *} \\
(0.0442)\end{array}$ & $\begin{array}{c}0.820^{* * *} \\
(0.0361)\end{array}$ & $\begin{array}{c}0.822^{\text {*** }} \\
(0.0449)\end{array}$ & $\begin{array}{c}0.750^{* * *} \\
(0.0486)\end{array}$ & $\begin{array}{c}0.743^{* * *} \\
(0.0497)\end{array}$ \\
\hline Labour (\%black) & $\begin{array}{c}-1.314^{* * *} \\
(0.444)\end{array}$ & $\begin{array}{r}-\mathbf{1 . 2 6 3} \\
(0.780)\end{array}$ & $\begin{array}{c}-\mathbf{1 . 3 1 8}^{\text {****}} \\
(0.443)\end{array}$ & $\begin{array}{r}-\mathbf{1 . 2 6 5} \\
(0.850)\end{array}$ & $\begin{array}{c}-1.347^{* *} \\
(0.584)\end{array}$ & $\begin{array}{c}-\mathbf{2 . 8 7 9 *} \\
(1.702)\end{array}$ \\
\hline Inequality (\%white l.less) & $\begin{array}{c}-0.663^{* *} \\
(0.286)\end{array}$ & $\begin{array}{c}-0.665^{* *} \\
(0.276)\end{array}$ & $\begin{array}{c}-0.651^{* *} \\
(0.289)\end{array}$ & $\begin{array}{c}-0.653^{* *} \\
(0.278)\end{array}$ & $\begin{array}{c}-0.812^{* *} \\
(0.333)\end{array}$ & $\begin{array}{c}-0.850^{* *} \\
(0.336)\end{array}$ \\
\hline Ethnic fractionalization & $\begin{array}{r}-0.0720 \\
(0.183)\end{array}$ & $\begin{array}{r}-0.0691 \\
(0.190)\end{array}$ & & & & \\
\hline Religious fractionalization & & & $\begin{array}{r}-0.0697 \\
(0.122)\end{array}$ & $\begin{array}{r}-0.0669 \\
(0.132)\end{array}$ & & \\
\hline Urbanisation & $\begin{array}{c}-0.0148 \\
(0.159)\end{array}$ & $\begin{array}{c}-0.0223 \\
(0.171)\end{array}$ & $\begin{array}{r}-0.0371 \\
(0.164)\end{array}$ & $\begin{array}{r}-0.0440 \\
(0.170)\end{array}$ & $\begin{array}{c}-0.00505 \\
(0.246)\end{array}$ & $\begin{array}{r}-0.0262 \\
(0.243)\end{array}$ \\
\hline Population density & $\begin{array}{c}0.00324 \\
(0.00430)\end{array}$ & $\begin{array}{c}0.00325 \\
(0.00422)\end{array}$ & $\begin{array}{c}0.00310 \\
(0.00414)\end{array}$ & $\begin{array}{c}0.00312 \\
(0.00405)\end{array}$ & $\begin{array}{c}0.00886 \\
(0.00656)\end{array}$ & $\begin{array}{c}0.00815 \\
(0.00640)\end{array}$ \\
\hline Year control & $\checkmark$ & $\checkmark$ & $\checkmark$ & $\checkmark$ & $\checkmark$ & $\checkmark$ \\
\hline Colony fixed effects & & & & & $\checkmark$ & $\checkmark$ \\
\hline Additional controls & $\checkmark$ & $\checkmark$ & $\checkmark$ & $\checkmark$ & $\checkmark$ & $\checkmark$ \\
\hline Scotch-Irish migration trend & & & & & $\checkmark$ & $\checkmark$ \\
\hline $\begin{array}{l}\text { Observations } \\
\text { Mean suffrage } \\
R^{2}\end{array}$ & $\begin{array}{l}412 \\
3.633 \\
0.841\end{array}$ & $\begin{array}{l}412 \\
3.633 \\
0.841\end{array}$ & $\begin{array}{l}412 \\
3.633 \\
0.841\end{array}$ & $\begin{array}{r}412 \\
3.633 \\
0.841\end{array}$ & $\begin{array}{r}412 \\
3.633 \\
0.848\end{array}$ & $\begin{array}{l}412 \\
3.633 \\
0.846\end{array}$ \\
\hline $\begin{array}{l}\text { First-Stage Results } \\
\text { Instrument Coefficient } \\
1^{\text {st }} \text { stage } R^{2}\end{array}$ & & $\begin{array}{l}0.394 * * * \\
(0.042) \\
0.825\end{array}$ & & $\begin{array}{c}0.332 * * * \\
(0.040) \\
0.818\end{array}$ & & $\begin{array}{l}0.249 * * * \\
(0.048) \\
0.952\end{array}$ \\
\hline
\end{tabular}

Sources: See text. Notes: This table shows results from OLS and 2SLS regressions explaining suffrage in the 13 British American colonies (robustness checks). All independent variables are lagged by one period (three years). A linear trend is used as "Year control". Additional controls include a dummy for when each colony was proprietary or charter (with royal as omitted category). Robust standard errors are in parentheses. ${ }^{* * *} p \leq 0.01,{ }^{* *} p \leq 0.05,{ }^{*} p \leq 0.1$. 
Table A6: Suffrage in the 13 colonies: Robustness checks 5

\begin{tabular}{|c|c|c|c|c|c|c|c|}
\hline & $\begin{array}{c}(1) \\
\text { OLS } \\
\text { No FEs }\end{array}$ & $\begin{array}{c}(2) \\
2 \mathrm{SLS} \\
\text { No FEs }\end{array}$ & $\begin{array}{c}(3) \\
\text { OLS } \\
\text { No Lagged } \\
\text { Dep. Var }\end{array}$ & $\begin{array}{c}(4) \\
\text { 2SLS } \\
\text { No Lagged } \\
\text { Dep. Var }\end{array}$ & $\begin{array}{c}(5) \\
\text { OLS } \\
\text { No Lagged } \\
\text { Dep. Var } \\
\text { No FEs }\end{array}$ & $\begin{array}{c}(6) \\
\text { 2SLS } \\
\text { No Lagged } \\
\text { Dep. Var } \\
\text { No FEs }\end{array}$ & $\begin{array}{c}(7) \\
\text { OLS } \\
10 \text { year avg. }\end{array}$ \\
\hline Lagged Suffrage & $\begin{array}{c}0.820^{* * *} \\
(0.0360)\end{array}$ & $\begin{array}{c}0.817^{* * *} \\
(0.0484)\end{array}$ & & & & & $\begin{array}{c}0.493^{* * *} \\
(0.0906)\end{array}$ \\
\hline Inequality (\%white 1.less) & $\begin{array}{c}-0.673^{* *} \\
(0.285)\end{array}$ & $\begin{array}{c}-0.670^{* *} \\
(0.275)\end{array}$ & $\begin{array}{c}-1.615^{* * *} \\
(0.512)\end{array}$ & $\begin{array}{c}-1.523^{* * *} \\
(0.518)\end{array}$ & $\begin{array}{c}-1.415^{* * *} \\
(0.477)\end{array}$ & $\begin{array}{c}-1.340^{* * *} \\
(0.481)\end{array}$ & $\begin{array}{c}-1.880^{* * *} \\
(0.656)\end{array}$ \\
\hline Urbanisation & $\begin{array}{c}-0.000913 \\
(0.154)\end{array}$ & $\begin{array}{c}0.0146 \\
(0.196)\end{array}$ & $\begin{array}{c}1.190^{* *} \\
(0.579)\end{array}$ & $\begin{array}{c}0.958^{*} \\
(0.535)\end{array}$ & $\begin{array}{c}0.482 \\
(0.383)\end{array}$ & $\begin{array}{c}0.652 \\
(0.414)\end{array}$ & $\begin{array}{c}-0.549 \\
(0.668)\end{array}$ \\
\hline Year control & $\checkmark$ & $\checkmark$ & $\checkmark$ & $\checkmark$ & $\checkmark$ & $\checkmark$ & $\checkmark$ \\
\hline Colony fixed effects & & & $\checkmark$ & $\checkmark$ & & & $\checkmark$ \\
\hline Additional controls & $\checkmark$ & $\checkmark$ & $\checkmark$ & $\checkmark$ & $\checkmark$ & $\checkmark$ & $\checkmark$ \\
\hline $\begin{array}{l}\text { Observations } \\
\text { Mean suffrage } \\
R^{2}\end{array}$ & $\begin{array}{l}412 \\
3.633 \\
0.841\end{array}$ & $\begin{array}{l}412 \\
3.633 \\
0.841\end{array}$ & $\begin{array}{r}412 \\
3.633 \\
0.498\end{array}$ & $\begin{array}{l}412 \\
3.633 \\
0.469\end{array}$ & $\begin{array}{r}412 \\
3.633 \\
0.376\end{array}$ & $\begin{array}{l}412 \\
3.633 \\
0.371\end{array}$ & $\begin{array}{r}123 \\
3.627 \\
0.749\end{array}$ \\
\hline $\begin{array}{l}\text { First-Stage Results } \\
\text { Instrument Coefficient }\end{array}$ & & $\begin{array}{l}0.248 * * * \\
(0.036)\end{array}$ & & $\begin{array}{l}0.390 * * * \\
(0.053)\end{array}$ & & $\begin{array}{l}0.311 * * * \\
(0.033)\end{array}$ & \\
\hline
\end{tabular}

Sources: See text. Notes: All independent variables are lagged by one period (three years for column 1 - 6, ten years for column 7 ). A linear trend is used as "Year control". Additional controls include a dummy for when each colony was proprietary or charter (with royal as omitted category). Robust standard errors are in parentheses. ${ }^{* * *} p \leq 0.01,{ }^{* *} p \leq 0.05,{ }^{*} p \leq 0.1$. 
Table A7: Suffrage in the 13 colonies: Main specification, without inequality (percent landless)

\begin{tabular}{|c|c|c|c|c|}
\hline & $\begin{array}{c}(1) \\
\text { OLS }\end{array}$ & $\begin{array}{l}(2) \\
\text { OLS }\end{array}$ & $\begin{array}{c}(3) \\
\text { 2SLS }\end{array}$ & $\begin{array}{c}(4) \\
\text { OLS } \\
\text { Inequality } \\
\text { above median }\end{array}$ \\
\hline Lagged Suffrage & $\begin{array}{l}0.785^{* * *} \\
(0.0429)\end{array}$ & $\begin{array}{l}0.750^{* * *} \\
(0.0550)\end{array}$ & $\begin{array}{l}0.824^{* * *} \\
(0.0377)\end{array}$ & $\begin{array}{l}0.666^{* * *} \\
(0.0880)\end{array}$ \\
\hline Labour (\%black) & $\begin{array}{l}-\mathbf{1 . 1 4 9} \\
(0.226)\end{array}$ & $\begin{array}{c}-\mathbf{1 . 5 5 4} 4^{* *} \\
(0.606)\end{array}$ & $\begin{array}{c}-\mathbf{1 . 7 3 0 *} \\
(0.947)\end{array}$ & $\begin{array}{l}-1.855^{* * *} \\
(0.678)\end{array}$ \\
\hline Urbanisation & $\begin{array}{c}0.0478 \\
(0.172)\end{array}$ & $\begin{array}{c}0.395 \\
(0.296)\end{array}$ & $\begin{array}{c}0.309 \\
(0.221)\end{array}$ & $\begin{array}{c}1.065^{*} \\
(0.557)\end{array}$ \\
\hline Population density & $\begin{array}{c}0.00216 \\
(0.00552)\end{array}$ & $\begin{array}{c}0.0138 \\
(0.00942)\end{array}$ & $\begin{array}{c}0.00493 \\
(0.00619)\end{array}$ & $\begin{array}{c}0.0265 \\
(0.0209)\end{array}$ \\
\hline Year control & $\checkmark$ & $\checkmark$ & $\checkmark$ & $\checkmark$ \\
\hline Colony fixed effects & & $\checkmark$ & $\checkmark$ & $\checkmark$ \\
\hline Additional controls & $\checkmark$ & $\checkmark$ & $\checkmark$ & $\checkmark$ \\
\hline Observations & 491 & 491 & 464 & 279 \\
\hline Mean suffrage & 3.618 & 3.618 & 3.594 & 3.497 \\
\hline$R^{2}$ & 0.766 & 0.775 & 0.843 & 0.737 \\
\hline $\begin{array}{l}\text { First-Stage Results } \\
\text { Instrument Coefficient }\end{array}$ & & & $\begin{array}{l}0.386 * * * \\
(0.045)\end{array}$ & \\
\hline $1^{\text {st }}$ stage $R^{2}$ & & & 0.894 & \\
\hline
\end{tabular}

Sources: see text. Notes: This table shows results from OLS and 2SLS regressions explaining the suffrage in the 13 British American colonies, excluding inequality (percent landless). Independent variables are lagged by one period (three years). Additional controls include a dummy for when each colony was proprietary or charter (with royal as omitted category). A linear trend is used as "Year control". Robust standard errors are in parentheses. ${ }^{* * *} p \leq 0.01,{ }^{* *} p \leq 0.05$, ${ }^{*} p \leq 0.1$. 
Table A8: Suffrage in the 13 colonies: different specifications of the IV estimating equation

\begin{tabular}{|c|c|c|c|c|}
\hline & $\begin{array}{c}(1) \\
\text { 2SLS } \\
\text { Baseline }\end{array}$ & $\begin{array}{c}(2) \\
\text { 2SLS } \\
\text { No col. f.e. }\end{array}$ & $\begin{array}{c}(3) \\
\text { 2SLS } \\
\text { No urb. } \\
\text { pop.dens. }\end{array}$ & $\begin{array}{c}(4) \\
\text { 2SLS } \\
\text { No urb., } \\
\text { pop.dens. } \\
\text { ineq. }\end{array}$ \\
\hline Lagged Suffrage & $\begin{array}{c}0.769^{* * *} \\
(0.0529)\end{array}$ & $\begin{array}{c}0.816^{* * *} \\
(0.0494)\end{array}$ & $\begin{array}{c}0.772^{* * *} \\
(0.0532)\end{array}$ & $\begin{array}{c}0.829^{* * *} \\
(0.0377)\end{array}$ \\
\hline Labour (\%black) & $\begin{array}{c}-\mathbf{2 . 6 0 8}^{* *} \\
(1.324)\end{array}$ & $\begin{array}{c}-\mathbf{1 . 1 2 1} \\
(0.672)\end{array}$ & $\begin{array}{c}-\mathbf{2 . 7 3 7} \\
(1.314)\end{array}$ & $\begin{array}{c}-\mathbf{1 . 8 0 2}^{* *} \\
(0.918)\end{array}$ \\
\hline Inequality (\%white l.less) & $\begin{array}{c}-0.691^{* *} \\
(0.316)\end{array}$ & $\begin{array}{r}-0.516^{*} \\
(0.310)\end{array}$ & $\begin{array}{c}-0.663^{* *} \\
(0.317)\end{array}$ & \\
\hline Urbanisation & $\begin{array}{c}0.140 \\
(0.223)\end{array}$ & $\begin{array}{r}-0.0475 \\
(0.160)\end{array}$ & & \\
\hline Population density & $\begin{array}{c}0.00554 \\
(0.00621)\end{array}$ & $\begin{array}{r}0.000966 \\
(0.00471)\end{array}$ & & \\
\hline Year control & $\checkmark$ & $\checkmark$ & $\checkmark$ & $\checkmark$ \\
\hline Colony fixed effects & $\checkmark$ & & $\checkmark$ & $\checkmark$ \\
\hline Additional controls & $\checkmark$ & $\checkmark$ & $\checkmark$ & $\checkmark$ \\
\hline Observations & 412 & 412 & 412 & 464 \\
\hline Mean suffrage & 3.633 & 3.633 & 3.633 & 3.594 \\
\hline$R^{2}$ & 0.842 & 0.839 & 0.841 & 0.842 \\
\hline \multicolumn{5}{|l|}{ First-Stage Results } \\
\hline Instrument Coefficient & $\begin{array}{l}0.320 * * * \\
(0.046)\end{array}$ & $\begin{array}{l}0.372 * * * \\
(0.064)\end{array}$ & $\begin{array}{l}0.325 * * * \\
(0.046)\end{array}$ & $\begin{array}{l}0.402 * * * \\
(0.044)\end{array}$ \\
\hline $1^{\text {st }}$ stage $R^{2}$ & 0.924 & 0.509 & 0.923 & 0.893 \\
\hline
\end{tabular}

Sources: see text. Notes: This table shows results from SLS regressions explaining the suffrage in the 13 British American colonies, using different specifications of the IV estimating equation. Independent variables are lagged by one period (three years). Additional controls include a dummy for when each colony was proprietary or charter (with royal as omitted category). A linear trend is used as "Year control". Robust standard errors are in parentheses. ${ }^{* * *} p \leq 0.01,{ }^{* *} p \leq 0.05,{ }^{*} p \leq 0.1$. 


\section{Part 3: Detailed description of the data (to complement dis- cussion of data in main text)}

Suffrage These data are available annually from the first year of a colony's settlement to 1775 from McKinley (1905). The list of coded suffrage restrictions includes: (1) being a free person (indentured servants were not considered free during the terms of the indenture); (2) the possession of land, or the combination of house and land ("freeholding"); (3) the possession of income or property; (4) whether a minimum freeholding, property or income amounts were required; (5) tax paying (such as income or poll taxes); (6) residency in the colony in which voting was taking place; (7) holding any particular religious belief; (8) being a non-felon; (9) being white; (10) the possession of a house; (11) having a particular social status, such as men with a family, being the son of a freeholder, or being a person of "good moral character"; (12) any other requirements, such as having one's land formally patented. Since all colonies allowed only men aged 21 and above to vote, I do not account separately for restrictions related to gender or age.

Labour markets: percent black and white population density The data are available from Historical Statistics of the United States, Millennial Edition Online (2006), in ten-year periods from 1610-1780. Missing values are filled in by linear interpolation. The size of each colony is from Purvis (1999, p.19) and Purvis and Balkin (1995, p.243-244). Note that for Maine I use the settled area by 1800 instead of the area of the modern state.

Labour markets: Caribbean slave prices Eltis et al. (2005) provide these data in sterling per slave, based on constant prices. The years covered are 1674, as well as five-year periods from then onward until 1775 (for instance, 1675-1679). Data for the period 1638-1672 are also only available in five-year periods and come from 
United States Bureau of the Census (1975, p. 1174). Unfortunately, the latter data are not adjusted for inflation, as the US-wide consumer price index (CPI) only starts in 1665. Potential biases should be mitigated by the use of English pounds sterling, which should absorb to some extent inflationary shocks to the domestic currency (see also the discussion on the crop index IV below).

Labour markets: instrumental variable I compile the time-invariant crop suitability weights from the Food and Agriculture Organization of the United Nations Global Agro-Ecological Zones (GAEZ) 2010 database (FAO, accessed April 5, 2012).

Crop prices are from Historical Statistics of the United States, Millennial Edition Online (2006). Prices for tobacco are an average of the prices for all sweetscented Virginia tobacco, which are available annually for the period 1647-1775. Missing years (1670, 1672 and 1673) are calculated via linear interpolation. The regions included in the calculation of the tobacco prices include: York River Basin, New Kent And King William Counties, Rappahannock River Basin, Potomac River Basin, Hanover And Louisa Counties, and Virginia Piedmont.

Wheat prices cover the period 1680-1775. The data are annual, and those from 1680-1763 are from Purvis (1999, p.77) (covering Talbot County, Maryland), while prices for 1763-1775 are from Historical Statistics of the United States, Millennial Edition Online (2006) (calculated as an average of the prices in Maryland's Eastern and Western shores). Missing years (1689-1693; 1695) are filled via linear interpolation. The 1680 prices are used to fill in the missing prices for the period 1647-1680.

Rice prices are available annually from 1701-1775 and cover Charleston, SC.

Exchange rate data. The crop prices are converted from local currency to English pence per pound using exchange rate data from Historical Statistics of the United States, Millennial Edition Online (2006). For Virginia, the data are available 
for 1691, and then annually from 1708 to 1775. Years between 1691-1708 are filled via linear interpolation, and the 1691 values are assumed to persist backward to 1647 . For Maryland, I use data on hard currency exchange rates, which are available for the years 1702, 1709, as well as annually for the period 1715-1776. Missing values are filled via linear interpolation, and the 1702 values are assumed to persist backward to 1647. For South Carolina, the data are available annually for 1699-1775. The 1699 values are used to fill in the missing values for the period 1647-1699.

Since general price data are not available on a colony-by-colony basis (West, 1978), the crop prices are, unfortunately, not adjusted for inflation. To address this, I adopt three approaches. First, as explained in the main text, when calculating the crop index, I divide the suitability of growing rice or tobacco, multiplied by the respective crop price, by the suitability of growing wheat, multiplied by its price. As a result, each colony's revenue earning potential for tobacco and rice is calculated relative to price changes in wheat. Moreover, inflationary pressures during the colonial era were relatively low, at least when the colonies were not at war. For example, even in colonial New England, which was considered to have managed its bills of credit relatively badly, inflation during peacetime was only $5 \%$ per annum. In contrast, during wartime, such as King George's war of 1744-1748, inflation in New England was around 35\% per year (Michener, 2003). To the extent that wars were a shock common to all colonies, their effects should be captured by the time fixed effects which I include in all regressions. In addition, colony and regional trends should address the possibility that wars affected the price index in some colonies (and regions) more disproportionately than in others (see the robustness checks presented in Table 3). Finally, given the paucity of price indices that cover both individual colonies as well as all colonies, the behaviour of the sterling exchange rate should capture to a large extent fluctuations in the colonial currencies (personal communication with Ron Michener, 20 March 2014). 
Inequality: percent white landless I assemble the data set on the share of each colony's white male landless population from Kulikoff (1986, 2000), Main (1965), and Nash (1979). Because the data are only available for certain years, I assign colonies with missing values regional-level data whenever they are available, and fill in any remaining missings via linear interpolation. The data set covers a total of 103 observations for the period 1655 to 1775 , with around $15 \%$ of the observations covering the period 1655-1710. While the sources generally give a particular year for each landless data point, sometimes they are less precise, and I use my best judgement to handle such cases. For instance, Kulikoff (2000) indicates that in the early eighteenth century, around $1 / 9$ of Pennsylvania residents were without land. I therefore assume that the share of Pennsylvania's white landless was $1 / 9$ from 1700 to 1710 .

To fill in missing values, I proceed in two steps. I first use non-missing regionallevel values based on a narrow regional classification: Lower South (NC, SC); Upper South (VA, MD); New England (MA, NH, RI, ME, CT) and the Middle Colonies (NY, NJ, PA and DE). I then fill in the remaining missing values using linear interpolation.

While the adopted approach is only a second-best solution to using detailed historical data on income inequality, there are several reasons why the inequality data used in this paper should yield adequate estimates of the income distribution in each colony. First, filling in missing values with data from either neighbouring countries or regional-level averages is a widely used tool in the literature. For instance, when calculating world-wide inequality in the period 1820-1992, Bourguignon and Morrisson (2002) face the problem of missing data for GDP per capita and population for a large group of Eastern European and non-European countries. To fill in the gaps, the authors make use of growth data for comparable neighbouring countries. To minimise the number of missing values, Acemoglu et al. (2001) assign colonial 
settler mortality rates (covering the late eighteenth and early nineteenth century) to neighbouring countries, since closely located countries are likely to have similar disease environments. A somewhat similar - albeit arguably less precise - approach is also undertaken by Pritchett (1997), who simply proxies income per capita in the world's poorest countries by estimating a lower bound of USD 250 .

Second, linear interpolation between data values that are not available annually is also a standard approach in the literature using historical - as well as contemporary - inequality measures (see, for instance Boix (2003) and Lupu and Pontusson (2011)). Third, one can employ at least two econometric techniques to mitigate the potential biases arising from the implemented estimation technique. The issue of within-colony and within-region clustering should be alleviated by clustering the standard errors as well as by using colony and regional trends, along with colony fixed effects (Albouy, 2012). As already discussed, these results are available in Table 3 and are remarkably similar to those in the baseline specification. Moreover, dropping inequality (Table A7) from the baseline regressions changes the coefficients of interest very little, suggesting that my results are not likely to be driven by coding peculiarities in the inequality variable.

Although percent landless should capture to a considerable extent movements in colonial inequality, it is of course possible that this variable also accounts for other factors that may have an important - and independent - effect on the evolution of representative institutions. A first possibility is that it simply is a proxy for differences in poverty rates across colonies. Colonies with many poor people may be less likely to extend the suffrage, possibly because of the high cost of sustaining a democratic system. Similarly, poor constituents may be less informed and may be less likely to demand a change in political institutions. Alternatively, it is possible that disgruntled and disenfranchised poor colonists may mobilise themselves in a rebellion with the aim of obtaining the suffrage. 
Even though I cannot rule out a priori that percent landless also proxies for these other factors, there are several pieces of evidence that point against their importance. First, persistent cross-colony income differences should be captured by the colony fixed effects, while time-varying shifts in economic development are likely correlated with population density and urbanisation for which the regressions also control. Second, adequate government financing was never really an issue for any of the colonies (Rabushka, 2010). Moreover, literacy rates were uniformly high throughout the colonial period in both the Northern and the Southern colonies (mostly in the range 60\%-80\%), suggesting that information asymmetries across voters were less extensive (Grubb, 1990). Finally, although some colonies did experience revolts by disenfranchised poor voters, the discussion in the penultimate section of the paper suggests that their impact on political institutions was less clear-cut and short-lived.

Additional controls Data on the type of colonial settlement (proprietary, charter or royal) is available annually from Purvis (1999).

Urbanisation is calculated by dividing each colony's total urban population (from Purvis (1999) and Purvis and Balkin (1995)) by the settled area (for the latter, see the sources in the description of population density). The urban population data include the following years and cities: Boston, MA, 1630-1775 (every 5 years); Charleston, SC - 1680-1690 (every 5 years); 1710-1760 (every 10 years) and 1775; New York, NY: 1630-1775 (every 5 years); Newport, RI: 1640-1780, also including 1775 (every 10 years); Philadelphia, PA: 1685-1775 (every 5 years); Albany, NY: 1775; Baltimore, MD: 1775; Gloucester, MA: 1790 - assumed that this value was the same as in 1775; Hartford, CT: 1775; Lancaster, PA: 1780 - assumed that this value was the same as in 1775, Marblehead, MA: 1760, 1775; New Haven, CT: 1780 assumed that this value was the same as in 1775; New London, CT: 1700 - assumed that this value was the same as in 1775, Newburyport, MA: 1775, Norfolk, VA: 1775, 
Norwich, CT: 1775, Portsmouth, NH: 1775, Providence, RI: 1780 - assumed that this value was the same as in 1775, Richmond, VA: 1790 - assumed that this value was the same as in 1775, Salem, MA: 1760 and 1775, Savannah, GA: 1775. Missing values between years with available data are calculated via linear interpolation. Missing data prior to each colony's first year of available data are given a 0 value.

The latitude data were obtained from Tiger Map (Census Bureau). I use the latitude for each colony's state capital.

To calculate ethnic and religious fractionalisation, I collect colony-level data on the ancestral origins of the white population in 1790 and on the distribution of different types of churches in 1750 from

\section{Part 4: Historical evidence}

This subsection moves away from the large econometric tests undertaken in the rest of the paper. Instead, I test the proposed theory linking labour market structure and suffrage extensiveness by marshalling a number of primary and secondary historical sources, ranging from assembly records to promotional pamphlets. ${ }^{29}$ This microhistorical approach makes me more confident that labour markets did indeed have a causal effect on political institutions in the thirteen colonies.

I start by examining some (fragmentary) migration data covering the Northern and Southern colonies in the seventeenth and eighteenth centuries. If a liberal suffrage was indeed one of the effective ways to attract labour in the South in the seventeenth century, then the number of migrants coming to the South during this period should be higher than those in the North. In contrast, we should expect a reversal of this pattern after 1700. This is precisely what Table A9 demonstrates. The first panel contains information on the number of migrants in selected Southern

\footnotetext{
${ }^{29}$ See also Anonymous (2014) for a detailed historical analysis of the evolution of suffrage institutions in Virginia.
} 
and Northern colonies in the seventeenth century and shows that the flow of settlers coming to Virginia and Maryland during this period was nearly three times more than those choosing New England and Delaware. Due to lack of direct migration data, the second panel in the table proxies the number of foreign migrants with the share of the foreign-born population in each colony. With the exception of Maryland, eighteenth-century foreign migration had decreased substantially in the three remaining Southern colonies, at a level on a par with that in Massachusetts, and was significantly lower than the respective figures in Pennsylvania and Delaware.

\section{Evidence from the South}

Although detailed accounts of the motives of English migrants to the colonies are scant, several pieces of historical evidence support the idea that liberal representative institutions in the early South were used to attract labour. First, historians point out that assemblies appeared early in all colonies because they allowed rich planters to influence not only how each colony was governed, but also the fate of their own county or village (Cooper, 2000). In the seventeenth-century South, the most pressing issue for planters was securing a constant supply of English indentured servants. As one of Maryland's first promotional pamphlets (published in 1635) explains, a planter "may doe well to furnish himselfe with as many [servants] as he can, of useful and necessary Arts: A Carpenter, of all others the most necessary;... but any lusty young able man, that is willing to labour and take paines, although he have no particular trade, will be beneficial enough to his Master" (Hall, 1910, p. 98-99).

Southern elites, such as Edward Sandys, the treasurer of the Virginia Company, understood well that English immigration was instrumental for colonial development as well as for the profits of the Company, and that assemblies could play a crucial role in attracting migrants (Perry and Cooper 1959, p.48; Bruce 1910, p.404). Early Southern assemblies offered various concessions to indentured servants by issuing a 
Table A9: Migration to colonial British America, 1607-1775

(a) Before 1700: Total number of migrants

\begin{tabular}{lcccc} 
Years & Virginia & Maryland & New England & Delaware Valley \\
\hline $1607-1624$ & 6,000 & $\ldots$ & 400 & $\ldots$ \\
$1625-1633$ & 3,000 & $\ldots$ & 2,500 & $\ldots$ \\
$1634-1640$ & 8,800 & 700 & 17,500 & $\ldots$ \\
$1641-1650$ & 12,000 & 1,800 & 4,800 & $\ldots$ \\
$1651-1660$ & 18,500 & 4,600 & 3,600 & $\ldots$ \\
$1661-1670$ & 7,600 & 12,200 & 10,000 & $\ldots$ \\
$1671-1680$ & 7,400 & 12,400 & $\ldots$ & 1,000 \\
$1681-1700$ & 18,200 & 10,800 & $\ldots$ & 8,000 \\
\hline $1607-1700$ & 81,500 & 42,500 & 38,800 & 9,000
\end{tabular}

(b) After 1700: Percent of foreign-born residing in each colony

\begin{tabular}{lc} 
Colony & Per cent \\
\hline Maryland & $56 \%$ \\
Virginia & $20 \%$ \\
South Carolina & $16 \%$ \\
North Carolina & $9 \%$ \\
Pennsylvania & $74 \%$ \\
Delaware & $61 \%$ \\
New York & $10 \%$ \\
Massachusetts & $17 \%$ \\
New Hampshire & $10 \%$ \\
Maine & $9 \%$ \\
Connecticut & $5 \%$
\end{tabular}

Sources: Before 1700: Purvis (1999); after 1700: Villaflor and Sokoloff (1982). Notes: This table shows the number of migrants in selected colonies. Since data on the total number of migrants are not available after 1700 , it uses data on the share of the foreign-born from the colonial militia muster rolls covering the French and Indian war and the pre-revolutionary years. 
number of acts that regulated servant-master relations, sometimes as many as six annually. In Virginia in 1642, servants were given the right to seek the support of the local commissioner, who was the head of the county court appointed by the governor and the Council, for complaints about "harsh or vnchristianlike vsage or otherways for want of diet, or convenient necessaryes" (see Hening, 1819-1823, vol. 1, p. 255, ACT XXII). ${ }^{30}$ Several other acts also required masters to provide servants with decent clothing, food and lodging. To prevent the exploitation of indentured labourers, the Assembly issued statutes specifying the punishment that a master could enforce when a runaway servant was apprehended, such as the number of extra days such a servant had to serve (Smith, 1971, p. 266).

In the absence of a developed court system, the credibility of these regulations could only be sustained if migrant workers were allowed to participate in representative government as well, something which elites quickly realised. In Maryland, the proprietors decided to establish a liberal voting regime in order to compete for settlers with other colonies, especially because a Catholic proprietor could have discouraged some prospective colonists (Jordan, 2002, p.5). Similarly, although the North Carolina proprietors initially wanted to govern alone, a liberal franchise was implemented, at least until the province became more thickly settled (Raper, 1904, p.16). As a result, despite an English franchise restricted to freeholders, which excluded nearly $97 \%$ of the electorate, the majority of seventeenth-century Southern colonists were voters. $^{31}$ In pre-slavery Virginia, indentured servants could in fact vote until 1655, while freemen held the franchise in Maryland, North Carolina and South Carolina for most of the seventeenth century.

Moreover, the extensiveness of the suffrage was an important consideration for mi-

\footnotetext{
${ }^{30}$ The local commissioner was a type of assembly representative who was appointed by the governor and the Council.

${ }^{31}$ The size of the English electorate is from Acemoglu and Robinson (2012).
} 
grants. In 1624, all Virginia colonists issued a declaration stating that participation in representative government not only encouraged them to "follow their particular labours with singular alacrity and industry," but also had led to the establishment of many new plantations (Perry and Cooper, 1959, 49). Chute (1969) also gives an example of a group of highly-skilled Poles hired by the Virginia company which decided to settle in the colony because they were enfranchised and made inhabitants. The suffrage rights of new migrants also featured prominently in the Southern promotional literature. For example, a pamphlet published for the (South and North) Carolina proprietors in 1666 advertised both the generous land grants for which new settlers were eligible, and the fact that all free newcomers would be given the right to vote. Not only did these incentives attract a large number of migrants a few years later, but the early records of the colony also suggest that the proprietors did not renege on any of the promises made to new migrants (Salley, 1959).

In Maryland, the 1635 promotional pamphlet discussed earlier contains a section explaining that the proprietor could only implement laws that were also approved by the assembly, which in turn was to be elected by the greater number of free males in the colony (Hall, 1910, p. 104-105). In 1666, to recruit indentured servants, Maryland's proprietor Lord Baltimore commissioned a promotional narrative from a George Alsop, a former servant. ${ }^{32}$ An entire chapter is devoted to a discussion of Maryland's political system, and the existence of an annual assembly, elected by the consent of the people, is highlighted. Alsop also "advertises" several servant-friendly laws enacted by the Assembly, such as a law specifying that, upon completion of the indenture, a servant must receive from his master fifty acres of land, corn, three suits of clothes, as well as tools needed to set up his own farm. The book concludes that "The Servant of this Province, which are stigmatiz'd for Slaves by the clappermouth

\footnotetext{
${ }^{32}$ Although the language of this pamphlet is exaggerated, historians agree that most statements were truthful (Hall, 1910, p. 338).
} 
jaws of the vulgar in England, live more like Freemen then the most Mechanick Apprentices in London, wanting for nothing that is convenient and necessary, and according to their several capacities, are extraordinary well used and respected" (p. $378)$.

If liberal suffrage institutions were so prevalent in the South in the early seventeenth century, then how and why did they decline? Consistent with the theoretical and econometric analysis in the rest of the paper, the historical record suggests that the Southern political reversal was underpinned by the substitution of indentured servants with slaves. As labour market pressures subsided, political concessions to poor white workers were no longer profitable and the franchise was tightened in the late seventeenth and early eighteenth centuries. For instance, Cooper (2000, p. 9) argues that a major benefit of Africans, as compared to indentured servants, was that blacks could be permanently banned not only from landowning, but also from political life. In Maryland, the law to limit the franchise to freeholders, implemented in 1670, was debated intensely between the assembly and the Council. In the end, the winning argument was that even if such a policy drives out the majority of "able bodied" freemen, it is the welfare of the freeholders - and not that of the freemen that matters most. Similarly, in South Carolina, in sharp contrast to the rhetoric of the promotional pamphlets from only a few decades earlier, non-freeholding freemen were deemed not to "have an interest in this province" and excluded from voting in several laws enacted in the late 1600s and early 1700s (McKinley, 1905, p.146). ${ }^{33}$

\section{Evidence from the North}

While indentured servants comprised the majority of the Southern workforce for most of the seventeenth century, labour demand in the Northern colonies was met

\footnotetext{
${ }^{33}$ Election-related complaints were also considered to take too much time and to interfere with public business.
} 
mainly by family labour and only a small number of hired labourers. The temperate climate, along with the dominance of small-scale crops like wheat, kept the demand for additional workers low. As a result, political institutions in New England and the Middle colonies remained largely unchanged throughout the colonial period.

Instead of attracting labourers, suffrage institutions in the New England colonies were aimed at creating a closed community dominated by the initial settlers and emphasising the importance of religion. ${ }^{34}$ As a result, from the very beginning, a strict franchise including only church members emerged in Massachusetts, New Hampshire and Maine. Although Connecticut did not formally limit the suffrage on the basis of religion, historians suggest that church membership was likely as important as in Massachusetts, given the close link between church and township (McKinley, 1905, p. 389). Even in Rhode Island, which implemented the most liberal franchise regime of all the New England colonies, a religious qualification, limiting the freemanship and the suffrage to only Christians (excluding Roman Catholics), was adopted in 1719. Although less restrictive than the church-members' suffrage in the rest of the New England colonies, this regulation remained in force until the Revolution (McKinley, 1905, p. 430-462).

Even in those colonies where the religious qualification was eventually abolished, it was substituted with equally limiting freeholding requirements. In Massachusetts in 1664, ten new requirements for voting replaced those related to church membership, among which freeholding, residency and the need for a certificate from the "selectmen of one's town" (McKinley, 1905, p. 325). A similar - and likely even more restrictive - law was also adopted in New Hampshire in 1677 (McKinley, 1905,

\footnotetext{
${ }^{34}$ In Massachusetts, John Cotton, a pre-eminent minister, believed that "Democracy I do not conceive that God ever did ordain as a fit Government for Church or commonwealth" and that the liberty of electing deputies can only be entrusted to "churchmembers; for the liberties of the freemen of this commonwealth are such as require men of faithful integrity to God and the state to preserve the same" (McKinley, 1905, p. 305, 310).
} 
p. 374). What is more, New England elites could also influence who voted by controlling the admission of freemen in each township. Unlike in the Southern colonies where any person not bound to service was considered a freeman, new freemen in New England were accepted by deliberation of the respective towns. Some of the requirements that candidate freemen had to satisfy - such as freeholding or church membership - were similar to those imposed on voters. But there were also others, including provisions for good moral character, a tax and a monetary payment, as well as a probationary period, and a lengthy and laborious admissions process (McKinley p. 307-310, 382-387). Not surprisingly, the suffrage and freemaship requirements severely limited the number of eligible voters. In Massachusetts in 1631, the religious qualification excluded more than one half of the adult males, and freemen were only between one tenth to one twentieth of the population (McKinley, p. 313). Nearly forty years later, the colony had only 350 freemen out of a total population of 5,000 (McKinley, 1905, p. 307-310, 349, 382-387).

In the Middle colonies, English proprietors overtook a network of Dutch and Swedish settlements established in the early seventeenth century, which made attracting additional migrants less pressing. What is more, the English had fewer incentives to grant broad political freedoms to existing settlers, as Dutch and Swedish representative institutions were largely closed to the general population (McKinley, 1905, p. 259). ${ }^{35}$

This is not to say that colonial elites were unaware of how important political

\footnotetext{
${ }^{35}$ For example, although a quasi-representative board did come into existence in New York in 1642 , its members were appointed by the director in consultation with a rather narrow group composed of "masters and heads of families." In New Jersey, the only type of government that existed under the Dutch was in Bergen county and consisted of a four-person local court appointed by the New Amsterdam authorities. In Delaware and Pennsylvania, popular participation in government was similarly haphazard and never permanently established (McKinley, 1905, p. 176, 227, 273, 266-267).
} 
participation was for attracting settlers; rather, the evidence suggests that European and colonial governments simply had fewer incentives to make use of such policies. For instance, in a petition to the Dutch government in 1644, New York's governing body advocated, albeit unsuccessfully, establishing a representative assembly in which inhabitants "settle in suitable places, one near the other, in the form of villages or hamlets, and elect from among themselves a Bailiff or Schout and Schepens, who will be empowered to send their deputies and give their votes on public affairs with the Director and Council" (McKinley, 1905, p. 176-177).

In Delaware, the city of New Amstel, in an attempt to enlarge its population following its transfer from the Dutch West India company to Stuyvesant in 1656, advertised political privileges along with economic inducements to new settlers. However, the promised political institutions did not allow for popular elections of officeholders, but only for the "body of the burghers" to nominate fourteen magistrates, out of which the New Amsterdam director would appoint seven. Further political concessions, including an "election of commissaries" were implemented in the period 1657-1663, aimed at preventing the colonists from fleeing to English settlements, but ultimately none of these policies were successful and the city fell to the English in 1663 (McKinley, 1905, p. 262-264).

The availability of settlers, along with the limited governmental institutions under the Dutch and the Swedish, prompted English proprietors in the Middle colonies to opt for a relatively stable franchise regime which was limited to freeholders. In New York, the freeholder-only suffrage was implemented shortly after the transfer of the colony to the English in 1664, and with few additional changes (such as the exclusion of Catholics and Jews in 1701 and 1737, respectively), remained unchanged until the Revolution. Remaining Dutch settlers were offered additional concessions, such as the choice to become English citizens upon recognising the King's authority; the protection of property and land rights; the enforcement of Dutch rules of inheritance; 
and the freedom of conscience and worship (McKinley, 1905, p. 197). In New Jersey, where the original Dutch settlements were smaller and more sparsely populated, the inducements offered to current settlers were even broader. In addition to cheap land and "liberty of conscience," colonists were also promised a general assembly as well as chartered towns and cities. However, from very early on the suffrage was limited to freeholders, a policy which paralleled the franchise regimes adopted in Delaware and Pennsylvania. Similarly to New York, political institutions in these three colonies changed little throughout the colonial period (McKinley, 1905, p. 228; 274). ${ }^{36}$

In short, the historical evidence analysed in this sub-section supports the conclusions of the extensive econometric analysis undertaken in the rest of the paper. Representative institutions in the thirteen colonies were tightly linked to the structure of colonial labour markets. In the seventeenth-century South, a broad franchise (which in some cases allowed even indentured servants to vote) was aimed at attracting poor migrants from England. As bound labourers were replaced by slaves in the late 1700 s and early 1800 s, Southern political institutions deteriorated. In contrast, Northern political institutions, which were less inclusive than those in the pre-slavery South, remained largely unchanged throughout the colonial period, as Northern agriculture, conducted mainly on small family farms, did not require additional inflows of labour. In the New England colonies, a strict religious requirement for voting, along with a cumbersome procedure for gaining freemanship, created a closed community which favoured the original settlers. In the Middle colonies, a network of existing Dutch and Swedish settlements, along with their autocratic form of political organisation, enabled English proprietors to implement a restrictive franchise regime that was limited to freeholders.

\footnotetext{
${ }^{36}$ In Delaware, there were no popular elections from its overtake by the English in 1665 until 1682. From 1682 until 1702, the colony was part of Pennsylvania (McKinley, 1905, p. 266-270).
} 